\title{
Movement of small mammals across divided highways with vegetated medians
}

\author{
By
}

Ashley McLaren

\author{
A thesis submitted to \\ The Faculty of Graduate Studies and Research \\ In partial fulfillment of \\ the requirements for the degree of \\ Master of Science
}

Department of Biology

Carleton University

Ottawa, Ontario

July, 2009

(C), Ashley A.D. McLaren 


$\begin{array}{ll}\begin{array}{l}\text { Library and Archives } \\ \text { Canada }\end{array} & \begin{array}{l}\text { Bibliothèque et } \\ \text { Archives Canada }\end{array} \\ \begin{array}{l}\text { Published Heritage } \\ \text { Branch }\end{array} & \begin{array}{l}\text { Direction du } \\ \text { Patrimoine de l'édition }\end{array} \\ \begin{array}{l}\text { 395 Wellington Street } \\ \text { Ottawa ON K1A ON4 } \\ \text { Canada }\end{array} & \begin{array}{l}\text { 395, rue Wellington } \\ \text { Ottawa ON K1A ON4 } \\ \text { Canada }\end{array}\end{array}$

Your file Votro reference

ISBN: 978-0-494-60182-2

Our file Notre reference

ISBN: 978-0-494-60182-2

NOTICE:

The author has granted a nonexclusive license allowing Library and Archives Canada to reproduce, publish, archive, preserve, conserve, communicate to the public by telecommunication or on the Internet, loan, distribute and sell theses worldwide, for commercial or noncommercial purposes, in microform, paper, electronic and/or any other formats.

The author retains copyright ownership and moral rights in this thesis. Neither the thesis nor substantial extracts from it may be printed or otherwise reproduced without the author's permission.
AVIS:

L'auteur a accordé une licence non exclusive permettant à la Bibliothèque et Archives Canada de reproduire, publier, archiver, sauvegarder, conserver, transmettre au public par télécommunication ou par l'Internet, prêter, distribuer et vendre des thèses partout dans le monde, à des fins commerciales ou autres, sur support microforme, papier, électronique et/ou autres formats.

L'auteur conserve la propriété du droit d'auteur et des droits moraux qui protège cette thèse. $\mathrm{Ni}$ la thèse ni des extraits substantiels de celle-ci ne doivent être imprimés ou autrement reproduits sans son autorisation.
In compliance with the Canadian Privacy Act some supporting forms may have been removed from this thesis.

While these forms may be included in the document page count, their removal does not represent any loss of content from the thesis.
Conformément à la loi canadienne sur la protection de la vie privée, quelques formulaires secondaires ont èté enlevés de cette thèse.

Bien que ces formulaires aient inclus dans la pagination, il n'y aura aucun contenu manquant.

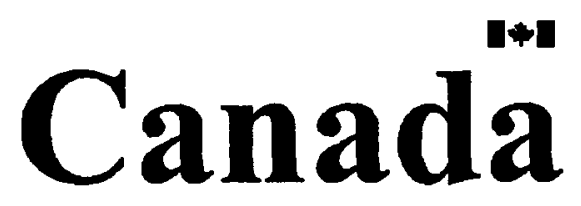




\section{ABSTRACT}

Previous studies suggest the gap in forest cover generated by roads contributes to the barrier effect of roads on forest-dependent small mammals. However, this concept has not been applied to movement across 4-lane highways containing vegetated medians of varying width. The purpose of my study was to determine whether median cover type or width affects small mammal crossings of divided highways. At each study site, I livetrapped small mammals along one side of the highway and translocated them to the opposite side of the highway using a standardized translocation distance. In total, $24 \%$ of translocated individuals were recaptured on the side of the highway of initial capture, but the overall probability of recapturing these individuals was not significantly related to median cover type or median width. My results suggest that efforts to mitigate the barrier effect of highways on small mammals cannot be accomplished by altering median vegetation and width. 


\section{ACKNOWLEDGEMENTS}

First and foremost, I would like to thank all the members of the Geomatics and Landscape Ecology Research Laboratory who made my M.Sc. experience enjoyable and rewarding. I could not have met a better group of people! I appreciate all of your support and feedback on my research. Lenore, I am so grateful for the opportunity I have had to be a member of this lab and I thank you for all your guidance along the way. I would especially like to thank Glenn Cunnington for always taking the time to answer my numerous field work or statistics questions and Trina Rytwinski for being my small mammals mentor.

Thank you to Nigel Waltho for your suggestions during my research planning and thesis write-up stages and Jeremy Kerr for being a part of my committee.

To the field students, Keegan McGrath, Sean Walkowiak, Robin Visser, and Laura Doubleday, my research would have felt more like work and less like a fun adventure in the forest without your help. Thanks for putting up with cleaning dirty, small mammal-smelling traps, not being afraid to walk beside busy highways, and dealing with mosquitoes, poison ivy, and flooded rain boots. I hope the great opportunities we had to see flying squirrels, ermines, and newborn voles made it all worthwhile.

The cooperation from private landowners, the National Capital Commission, and the United Counties of Prescott and Russell needs to be commended. Without the permission to use their land, my research would not have been possible. I found enjoyment from the landowners that were especially happy that I was going to be moving rodents away from their property to the other side of the highway (although I am not sure the landowners on the receiving end of my translocations shared this joy!). 
I have also been grateful for all the support given to me by my family and friends. It was always nice to share my trapping experiences with you and I hope I have made you look at little critters in a new light. Dad and Kristen, thanks for believing that nothing was out of reach for me, and Mom, you will always continue to inspire me.

A special thank you goes to Darren Sleep and Andrew de Vries, whose advice motivated me to get my Master's degree in the first place. My last-minute decision to apply to graduate school was a good one!

For all the small mammals that were brave enough to cross a 4-lane highway after experiencing being in a trap, getting an ear-tag piercing, riding along in a research vehicle, and then finally being dropped off in a new forest, you deserve 2 cheeks full of peanut butter/seed bait mixture!

Finally, to the other members of "the complex"—Patty and Keith—I am glad we were in all of this together! It was comforting to know that I was not the only one that had no idea what to do during our first semester in the lab. Since then, we have been a great support system for one another. I hope you both continue on the path of INGENUITIVE ecological work. 


\section{TABLE OF CONTENTS}

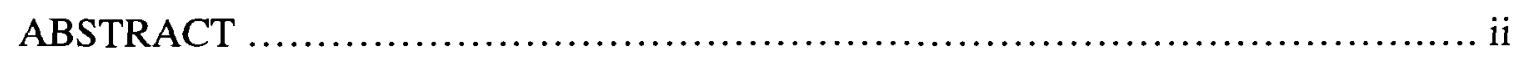

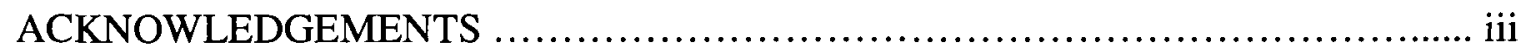

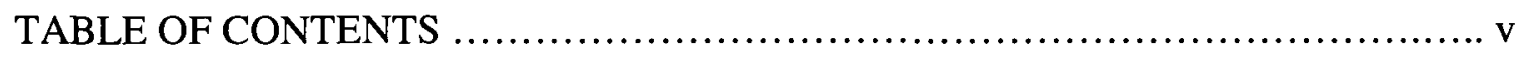

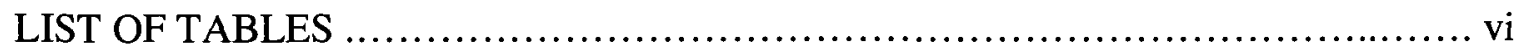

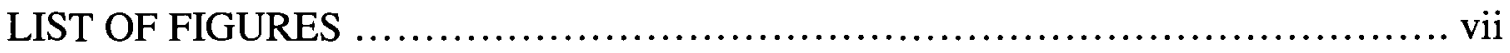

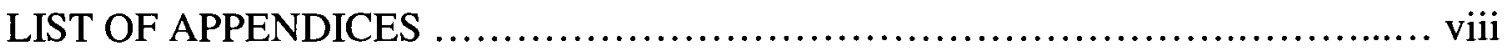

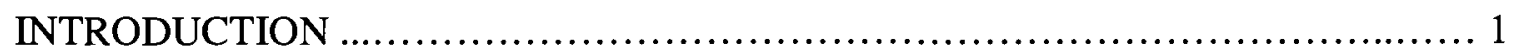

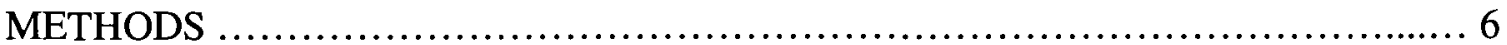

Sites, Small Mammal Trapping \& Translocations .............................. 6

Vegetation Surveys ........................................................ 9

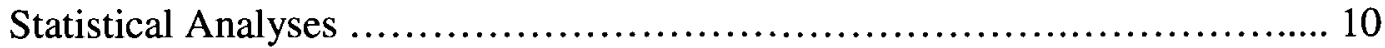

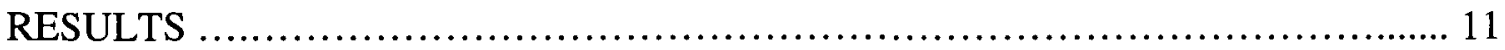

Analyses of Small Mammal Translocation Data .............................. 11

Analyses of Vegetation and Traffic Volume Data ............................. 14

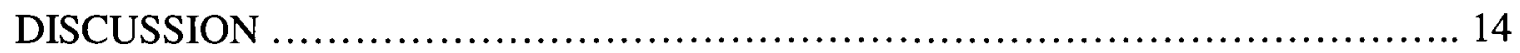

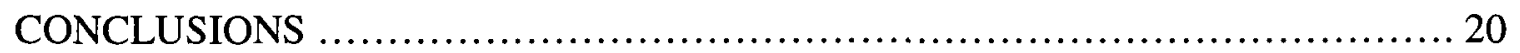

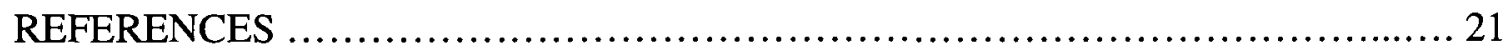




\section{LIST OF TABLES}

Table 1. Statistically significant results of t-tests comparing 11 vegetation measurements (tree dispersion, fallen log dispersion, proportion canopy cover, proportion vegetation cover, percent coarse woody debris, coniferous shrub density, deciduous shrub density, coniferous sapling density, deciduous sapling density, coniferous small tree density, deciduous small tree density) on trap vs. translocation sides of the highways for each study site. Negative t-values indicate the mean value is higher on the translocation side and positive $t$-values indicate the mean value is higher on the trap side of the highway

Table 2. Comparisons of median cover type and width to Annual Average Daily Traffic (AADT) and 11 vegetation characteristics on the translocation side of the 11 study sites. T-tests were performed to test for relationships with median cover type and regression analyses for relationships with median width. T-statistics represent the difference in the mean value of the variable at sites with grass medians and the mean value of the variable at sites with treed medians ......................................................... 26 


\section{LIST OF FIGURES}

Figure 1. Locations of 11 study sites along two 4-lane divided highways (Hwy 416 and 417 ) in the Ottawa region. Symbols represent the type of vegetation in the median at each

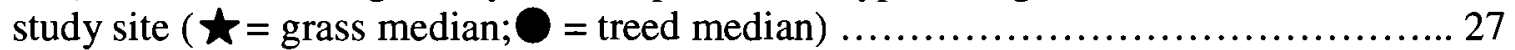

Figure 2. Illustration of a study site showing trapping grid on one side of highway and release location on other side. Total linear translocation distance from edge of trapping grid to release site was $114 \mathrm{~m}$ for all 11 sites .................................. 28

Figure 3. Number of individuals of 6 small mammal species that were recaptured (light bars) or not recaptured (dark bars) after translocation across 4-lane divided highways containing a central vegetated median at 11 study sites

Figure 4. (a) Combined number of individuals of 6 small mammal species recaptured ( $n=45$; light bars) and not recaptured $(n=145$; dark bars) during 7-day trapping sessions after translocation across highways containing grass or treed central dividing medians. The probability of recapturing translocated individuals was not significantly related to median cover type (Wald $\chi^{2}=0.052, \mathrm{P}=0.819$ ); (b) Recaptures (1)/non-recaptures ( 0 ) vs. median width $(\mathrm{m})$. The probability of recapturing an individual was not significantly

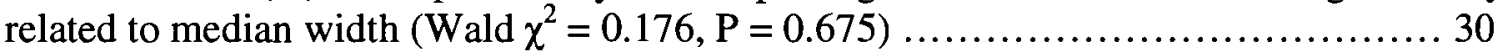

Figure 5. (a) Number of white-footed mice (Peromyscus leucopus) recaptured ( $\mathrm{n}=27$; light bars) and not recaptured ( $\mathrm{n}=44$; dark bars) during 7-day trapping sessions after translocation across highways containing grass or treed central dividing medians. The probability of recapturing translocated individuals was not significantly related to median cover type (Wald $\left.\chi^{2}=1.03 \times 10^{-4}, \mathrm{P}=0.992\right)$; (b) Number of translocated female $(\mathrm{n}=21$ ) and male $(\mathrm{n}=50)$ white-footed mice that were recaptured (light bars) and not recaptured (dark bars). The interaction effect between sex and median cover type was significant (Wald $\chi^{2}=5.394, \mathrm{P}=0.020$ ): the probability of recapturing females at highway sites with grass medians was significantly lower than at sites with treed medians 31

Figure 6. Number of southern red-backed voles (Clethrionomys gapperi) that were recaptured ( $n=8$; light bars) and not recaptured $(n=63$; dark bars) during 7-day trapping sessions after translocation across highways containing grass or treed central dividing medians. The probability of recapturing translocated individuals was not significantly related to median cover type (Wald $\chi^{2}=0.499, \mathrm{P}=0.480$ )

Figure 7. Boxplots (categorized by median cover type) showing the number of days during 7-day trapping sessions that it took to recapture the 45 of 190 small mammals that were translocated across divided highways $(\mathrm{t}=2.848 ; \mathrm{n}$ (grass) $=13, \mathrm{n}$ (trees) $=32 ; \mathrm{P}=$ 0.008). All individuals at grass median sites were recaptured within 1 day after translocation, except one individual that was recaptured after 3 days $\left(^{*}\right)$. At the treed median sites, the median number of days for recapture was 2 and the maximum was 4 days $(*)$ 33 


\section{LIST OF APPENDICES}

Appendix A. Results of multiple logistic regression analyses for (a) all species combined, (b) Peromyscus leucopus, and (c) Clethrionomys gapperi on the relationship between the probability of recapturing translocated individuals and median cover type, median width, median cover type $\times$ width (main predictors), species, sex, age class, days remaining in trapping session (confounding variables), and interactions of sex with median cover type and width 34

Appendix B. Locations of the 11 highway study sites used for trapping and translocation of small mammals near Ottawa, Ontario (NAD 1983 UTM Zone 18N) 36

Appendix C.1. Example of a 4-lane divided highway study site with a grass median (aerial and road-side images)

Appendix C.2. Example of a 4-lane divided highway study site with a treed median (aerial and road-side images) 38

Appendix D. Definitions of juvenile, sub-adult, and adult age classes used to categorize individuals of 6 small mammal species translocated across 11 highway study sites

Appendix E. Vegetation definitions (dominant tree species, coarse woody debris, fallen $\log$, non-woody vegetation cover, shrubs, saplings, small trees) used during vegetation data collection in $10 \times 10 \mathrm{~m}$ plots at the trap and translocation sides of each highway study site 40

Appendix F. Illustration of a $10 \times 10 \mathrm{~m}$ vegetation plot used to sample vegetation characteristics on the trap and translocation sides of each of the 11 study sites. Two $2 \times 2$ $\mathrm{m}$ plots were used to sample the density of coniferous and deciduous small trees, saplings, and shrubs. The $10 \times 10 \mathrm{~m}$ plot was centered on a tree marked with flagging tape in order to use the point-centered quarter method to measure tree dispersion and fallen log dispersion in each quarter. Other vegetation characteristics sampled per plot included: proportion of non-woody vegetation cover, proportion canopy cover, and percent of a $10 \mathrm{~m}$ transect covered by coarse woody debris

Appendix G. Results of multivariate general linear model analyses on the relationship between the proportion of individuals recaptured after translocation and median cover type, median width, and their interaction for (a) all data combined, (b) males, (c) females, (d) adults, and (e) juveniles. Proportion statistics were calculated for each of the 11 study sites as the number of individuals recaptured out of the total number of individuals translocated during the 7-day trapping session 
Appendix H. Proportion of small mammals that were recaptured during 7-day trapping sessions at 11 study sites after translocation across highways containing medians vegetated with grass $(\boldsymbol{O})$ or trees $(\mathbf{x})$. The proportion of individuals recaptured was not significantly related to median cover type $\left(F_{1,7}=0.145, \mathrm{P}=0.714\right)$ or median width $\left(\mathrm{F}_{1,7}=0.077, \mathrm{P}=0.790\right)$

Appendix I. Boxplots showing the marginally significant effect of median cover type on the proportion of females recaptured after translocation across divided highways during 7-day trapping sessions $\left(F_{1,7}=5.009, P=0.060\right)$ : most females were not recaptured when translocated across highways with grass medians, except at one site $\left(^{*}\right)$ where $20 \%$ of translocated females were recaptured. The proportion of males that were recaptured at the 11 study sites was not significantly related to median cover type $\left(\mathrm{F}_{1,7}=0.035, \mathrm{P}=0.858\right)$. [statistics from multivariate general linear model analyses in Appendix G]

Appendix J. Data collected during 7-day trapping sessions at the 11 highway study sites: start date of trapping session, site name with highway number (i.e. 416 or 417), individual recaptured (1) or not $(0)$, median width (m), median cover type, species (PL = Peromyscus leucopus; $\mathrm{PM}=$ Peromyscus maniculatus $; \mathrm{CG}=$ Clethrionomys gapperi $; \mathrm{TS}$ = Tamias striatus; $\mathrm{NI}=$ Napaeozapus insignis; $\mathrm{ZH}=$ Zapus hudsonius ), sex and age class of individual, number of days remaining in trapping session from day of release, and number of days between release and recapture of individual

Appendix K. Data from vegetation surveys using point-centered quarter method in $10 \times 10 \mathrm{~m}$ plots at the trap and translocation sides of the highway for each study site. For each quarter of the plots, tree dispersion was measured as the distance between the centre of the plot and the closest tree with a diameter at breast height $(\mathrm{DBH})>10.0 \mathrm{~cm}$. The distance between the centre of the plot and nearest fallen tree log in each quarter was used as a measurement of fallen $\log$ dispersion ..................................... 50

Appendix L. Vegetation data collected in $10 \times 10 \mathrm{~m}$ plots at the trap and translocation sides of the highway for each study site. Variables were measured as followed: summed length of coarse woody debris that covered a $10 \mathrm{~m}$ transect (\% coarse woody debris), number of times (out of 4) the crosshairs of the ocular tube intersected canopy cover (proportion canopy cover), and the total number of times (out of 20) non-woody vegetation was detected at randomly chosen points in the $10 \times 10 \mathrm{~m}$ plot (proportion

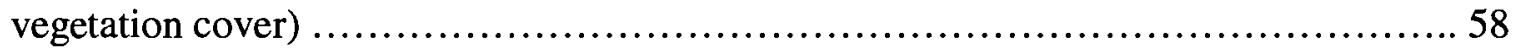

Appendix M. Counts of coniferous and deciduous shrubs, saplings, and small trees in $2 \times 2 \mathrm{~m}$ plots at the trap and translocation sides of the highway for the 11 study sites. Two $2 \times 2 \mathrm{~m}$ plots were sampled in each $10 \times 10 \mathrm{~m}$ vegetation plot 61 


\section{Introduction}

Roads are becoming prominent features in the landscape and the ecological impacts of those that bisect forests are important to consider. Surrounding wildlife populations, for example, can be affected by these roads directly (e.g. road mortality), but also indirectly (e.g. barrier to movement). Although the barrier effect of roads is less visible, it has been suggested to negatively affect populations through subdivision and demographic instability (Carr et al. 2002; Forman and Alexander 1998; Jaeger et al. 2005). As a result, an inability of wildlife to cross roads may decrease long-term population persistence.

Barriers to movement are relevant concerns for small mammal populations near roads, because these animals depend on mobility for acquiring resources and new territories. Translocation experiments have found that small mammals are capable of travelling long distances to return to their home range: southern red-backed vole (Clethrionomys gapperi) (600 m, Bovet 1980), deer mouse (Peromyscus maniculatus) (3,220 m, Murie and Murie 1931), and eastern chipmunk (Tamias striatus) (550 m, Seidel 1961). White-footed mice (Peromyscus leucopus) can move distances of over $14,000 \mathrm{~m}$ (Maier 2002). Regardless of whether these species travel such distances for dispersal or exploratory excursions, roads may impede the spatial requirements of these movements if individuals are unable or unwilling to cross roads in their environment. Therefore, it is essential to understand how roads can negatively affect the movement of small mammals.

Previous research on small mammals and roads has often focused on the association between road width and movement and negative effects have been found with 
increases in road width. In the Czech Republic, for example, more translocated yellownecked mice (Apodemus flavicollis) and bank voles (Clethrionomys glareolus) crossed a 2-lane highway than a 4-lane divided highway (Rico et al. 2007a). Similarly, fewer deer mice crossed a 4-lane divided highway in Kansas, compared to a 2-lane road, a gravel road, and a limestone road (Kozel and Fleharty 1979). Wilkins (1982) found that hispid cotton rats (Sigmodon hispidus) in Texas spontaneously crossed (i.e. without prior translocation) both 2-lane and 4-lane highways, but the frequency of crossings decreased with increasing lanes of pavement. Road crossings by hedgehogs have also been shown to decrease with increasing road width (Rondinini and Doncaster 2002). These studies suggest that wider roads have greater barrier effects on small mammal movement. However, an increase in road width is usually positively correlated with 2 variables: traffic volume and gap in forest cover. Traffic volume often increases with increasing number of road lanes, and therefore, it can be argued that the movement of small mammals across roads is influenced by traffic volume rather than road width. Nevertheless, translocations of white-footed mice and eastern chipmunks across 2-lane paved roads varying in traffic volume have found no significant effect of traffic on the probability of either species returning to their initial capture site (McGregor et al. 2008). Ford and Fahrig (2008) have also argued that eastern chipmunks avoid roads independently of traffic, because they found that few chipmunks crossed roads in their study area despite large variances in traffic volume, a result consistent with other small mammal studies (e.g. Goosem 2002; Oxley et al. 1974; Rico et al. 2007b). Therefore, the effect of traffic volume on road crossings by small mammals is likely not a significant factor. 
On the other hand, when roads subdivide forests, they generate an open gap, and the width of this gap in forest cover, not road width per se, may be the key factor in the barrier effect of roads on small mammal movement. Oxley et al. (1974) found that whitefooted mice and eastern chipmunks moved distances within trap grids that were similar to the widths of different roads and highways in their study area, yet crossings only occurred on roads with clearances of $30 \mathrm{~m}$ or less. In addition, decreased spontaneous road crossings were observed with increasing forest clearance. As a result, it was suggested that the distance an animal has to move between forest margins to cross a road is the most important inhibiting factor of road crossings by forest-dependent small mammals. Other species, including the yellow-necked mouse, bank vole, common shrew (Sorex araneus) (Rico et al. 2007b), and field vole (Microtus agrestis) (Richardson et al. 1997) also have been found to move distances within forests that were sufficient to cross roads, but they were reluctant to do so, providing evidence that road width may not be the most important factor limiting road crossings. This agrees with research in tropical rainforests where small mammals moved distances as much as ten times the width needed to cross an adjacent road. For the majority of species that did cross roads, crossings comprised less than $10 \%$ of all recorded movements (Goosem 2001). Other studies have shown that small mammals travel significantly less between trap grids placed on either side of a road, compared to grids placed a similar distance apart within continuous habitat (Clark et al. 2001; Conrey and Mills 2001; Mader 1984; McGregor et al. 2008). All of these examples provide evidence that small mammals are capable of large movement distances, and therefore, if they are inhibited by roads, even narrow ones, it may be due to the associated gap in forest cover. 
Additional support for the importance of protective cover for small mammal movements comes from research involving maintained powerline corridors. Schreiber and Graves (1977) found that white-footed mice and short-tailed shrews (Blarina brevicauda) were less likely to cross wide powerline corridors than narrow corridors. However, when translocations were conducted within a forest using similar distances to the powerline corridor widths, no significant differences in crossing rates occurred. In a similar study in Australia, small mammals travelled distances in the rainforest that were at least two times the width of a powerline corridor, yet they were severely inhibited by the cleared corridor. However, crossings occurred in sections of the corridor that contained regrowth vegetation and canopy cover (Goosem and Marsh 1997). Although not all small mammals may respond in a similar way to non-forested gaps (e.g. Bowman and Fahrig 2002), there is reason to believe that, in general, areas of forest clearance affect movement decisions by small mammals.

If forest clearance is the main reason small mammals are inhibited from crossing roads, then it may be a factor to consider when examining small mammal movement across divided highways with vegetated medians. Specifically, divided highways with wide, grassy medians may be greater barriers to movement than divided highways with narrow, treed medians. Trees between opposing lanes may reduce the forest clearance of a 4-lane highway, possibly creating the illusion of a 2-lane highway and a closer apparent forest edge for small mammals to perceive and orient towards (Lima and Zollner 1996; Zollner 2000). Additionally, narrow medians result in opposing lanes of traffic being closer together and consequently, forest margins on either side of the highway are closer together. A small mammal may not be able to perceive the width of a median, but it is 
likely to get more disoriented in a wide median, resulting in the inability to cross the entire highway.

Although some studies have examined the effect of multi-lane highways on small mammal movement, there is almost no research that specifically measures impacts of median barrier characteristics on movement (Kociolek and Clevenger 2007). Treed medians have been shown to be effective in facilitating highway crossings by arboreal species, such as the squirrel glider (Petaurus norfolcensis) (Cesarini 2007), but the effect of vegetated medians on highway crossings of non- or semi-arboreal species is unclear. Small mammals in Banff National Park were able to cross two lanes of the Trans-Canada Highway as well as the forested median; however, movement across the entire highway or any effects of the forested median were not examined (McDonald and St. Clair 2004). Other studies that have investigated small mammal crossings of 4-lane highways either (a) do not give a description of the what the median consisted of (or if one even existed) (Conrey and Mills 2001; Kozel and Fleharty 1979; Oxley et al. 1974; Rico et al. 2007a) or (b) describe the median, but do not address any potential role of the median itself in crossing rates (Garland and Bradley 1984; Wilkins 1982).

The purpose of my research was to test the predictions that (a) there will be more small mammal movement across 4-lane highways with treed medians than grassy medians, and (b) there will be more small mammal movement across 4-lane highways with narrow medians than wide medians. These predictions are based on the hypothesis that open space inhibits highway crossings by forest-dependent small mammals. 


\section{Methods}

\section{Sites, Small Mammal Trapping \& Translocations}

To test my predictions, I selected sites along two, 4-lane highways that varied in median width and contained trees or grass in the median. I translocated small mammals across the highways and monitored for return of individuals.

I conducted the mark-translocate-recapture study near Ottawa, Ontario from May to September, 2008. A $70 \mathrm{~m}$ highway section was used for each study site and consisted of paved traffic lanes that were approximately $3.75 \mathrm{~m}$ wide and had $1.5 \mathrm{~m}$ median shoulders and $3.0 \mathrm{~m}$ driving shoulders (Ministry of Transportation, pers. comm.). The width of the highway verges averaged $8.6 \mathrm{~m}$ and consisted of mowed grass and weedy vegetation. Annual Average Daily Traffic (AADT) in the research areas varied from 12,000 to 32,800 vehicles (Ministry of Transportation 2005). I used 11 study sites along the highways, with a minimum distance of $3 \mathrm{~km}$ between sites (Figure 1).

I selected study sites based on several criteria. First, I chose only sites along the highways where the central median could be classified into one of two categories: (1) trees in median or (2) low vegetation (i.e. grass) in median. The range of median widths for both cover type categories were similar (grass: $\sim 13$ to $45 \mathrm{~m}$; treed: $\sim 18$ to $50 \mathrm{~m}$ ). Second, I ensured that study sites did not contain lights, guardrails, culverts, and concrete barriers along the highway. Third, I selected sites with mixed deciduous forest on both sides of the highway. Common tree species included red maple (Acer rubrum), sugar maple (Acer saccharum), eastern white cedar (Thuja occidentalis), and black ash (Fraxinus nigra). Finally, I ensured that forest patch size was similar on both sides of the highway for each study site. 
At each site, I trapped small mammals in the forest along one side of the highway using Sherman non-folding aluminum live traps $(7.5 \times 9.0 \times 23.0 \mathrm{~cm}$; H.B. Sherman Traps Inc., Tallahassee, Florida). Traps were arranged in an $8 \times 8$ grid, with $10 \mathrm{~m}$ spacing between traps. Each trap was baited with a mixture of rolled oats, sunflower seeds, an apple slice, and peanut butter. A fist-sized amount of synthetic cotton batten was also placed in the traps. Traps were set each evening between 7:00 and 8:00 pm and checked the following morning between 8:00 and 9:00 am. I trapped for 7 days at each site (Day 1 was considered the first night traps were set), with the exception of two sites, which had two trapping sessions, one at the beginning and the other at the end of the field season, due to insufficient number of captures during the initial session. The 13 trapping sessions took place between May $4^{\text {th }}$ and September $12^{\text {th }}, 2008$ and the week each site was trapped was randomly selected.

Captured target species were weighed, sexed, assessed for reproductive condition, and noted for any health-related characteristics (e.g. botfly parasites and cuts or wounds). In addition, I categorized each animal as either adult (which included sub-adults) or juvenile based on weight and pelage colouration. Each animal was fitted with a $1 \mathrm{~g}$ Monel ear tag (National Band and Tag Co., Newport, Kentucky), except pregnant or lactating females which were not used during this study.

After tagging the animals, I translocated them to the other side of the highway to the release location—directly opposite to the trapping grid (Figure 2). Since it has been shown that translocation distance has a significant effect on return rates of translocated individuals (Cooke and Terman 1977; McGregor et al. 2008), I ensured that the translocation distance was constant across all sites. I set the translocation distance for all 
sites based on the study site that contained the widest median $(48.5 \mathrm{~m})$. At this site, the edge of the trapping grid and the release location were both $5 \mathrm{~m}$ into the forest from the tree line along the highway. From this site, I measured the linear distance from the edge of the trapping grid on one side of the highway to the release location on the other side of the highway using aerial photographs. This distance, $114 \mathrm{~m}$, was the translocation distance for all of my study sites and is well within the movement range of southern redbacked voles, deer mice, white-footed mice, and eastern chipmunks (see Introduction).

At the designated point of release for each study site, tagged individuals were released from a non-directional release box. The lid of this box was attached to a rope and pulley system that would lift up when pulled. Individuals were then free to leave the box in any direction (design details in Ford and Fahrig 2008). Each animal was allowed to acclimate to the box for approximately five minutes to limit stress-based dashes out of the box when opened. Also, I stood parallel to the highway and approximately 5 to $10 \mathrm{~m}$ away from the release box when it was pulled open to reduce biases in movement of the tagged animals. Translocations were conducted from Day 2 to 6 for each trapping session. No translocations were done on Day 7.

During each 7-day trapping session, I monitored daily for translocated animals on the trapping grid side of the highway. If such individuals were recaptured, I re-weighed them, recorded any visible changes in health, and noted the ear tag number. They were then released on the spot. No animals were translocated more than once.

All of my methods for capture, translocation, and release of target species were approved by the Animal Care Committee at Carleton University. 


\section{Vegetation Surveys}

The purpose of conducting vegetation surveys was, first, to ensure that similar habitat existed on both sides of the highway for each site. Second, and more importantly, I wanted to ensure that there were no consistent associations between vegetation type at the translocation side of the sites and median cover type or width. If the vegetation type at the point of release affected the animals' behaviour, this could confound any effects of median cover type and/or width. For example, if sites with treed medians had low quality habitat on the translocation side (e.g. low tree density or low amounts of coarse woody debris), then translocated animals might be motivated to move at these sites. This would produce an apparent effect of median vegetation that was actually caused by low quality of the release sites.

For each of the 11 sites, I sampled vegetation characteristics in four $10 \times 10 \mathrm{~m}$ plots, spaced $50 \mathrm{~m}$ apart in a square pattern, on both the trapping and translocation sides of the highways. Within each $10 \times 10 \mathrm{~m}$ plot, I measured: (1) cover of coarse woody debris using a $10 \mathrm{~m}$ transect, (2) presence of non-woody vegetation cover using 20 randomly selected points, (3) density of coniferous and deciduous small trees, saplings, and shrubs using two $2 \times 2$ m plots, and (4) tree dispersion and fallen log dispersion using the point-centered quarter method (Waite 2000). In addition, an ocular tube (PVC pipe with crosshairs at one end) was used to determine canopy cover at each corner of the $10 \times 10 \mathrm{~m}$ plot by holding the tube above the head and perpendicular to the ground and noting whether the crosshairs intersected leaves/branches (1) or sky (0). 


\section{Statistical Analyses}

I used multiple logistic regression analysis to test whether the probability of recapturing translocated individuals was related to the two median characteristics, cover type and width. Additionally, I tested for a possible interaction between cover type and width. I also included possible confounding variables: species, sex, age class, and days remaining in the trapping session (maximum possible $=5$ days). I first analyzed the data with all the species together and then individually for white-footed mice and southern red-backed voles, the two most abundant species in the data set. I also tested whether median cover type or width affected the number of days it took to recapture translocated individuals after their release using a t-test for median cover type and a linear regression for median width.

To test for any dissimilarity in vegetation characteristics between the two sides of the highway for each site, I compared the 11 vegetation characteristics at each site using t-tests. Finally, I tested for associations between vegetation characteristics at the translocation side of the sites and median cover type and width, as well as any associations between traffic volume at the sites and median cover type and width. I used t-tests to assess the relationships between the 11 vegetation variables and median cover type and between traffic volume (as measured by Annual Average Daily Traffic estimates) and median cover type. I used regression analyses to test for any relationships between the vegetation variables and median width and between traffic volume estimates and median width. 


\section{Results}

Analyses of Small Mammal Translocation Data

During 91 days of trapping, I captured and translocated 190 individuals (148 adults and 42 juveniles), $37 \%$ of which were white-footed mice and $37 \%$ were southern red-backed voles. Other species translocated included: eastern chipmunk, woodland jumping mouse (Napaeozapus insignis), meadow jumping mouse (Zapus hudsonius), and deer mouse. Non-target species captured included: flying squirrel (Glaucomys spp.), red squirrel (Tamiasciurus hudsonicus), masked shrew (Sorex cinereus), short-tailed shrew, and ermine (Mustela erminea).

Of the 190 individuals translocated across the highways, $45(23.7 \%)$ were recaptured on the side of the highway of initial capture within the 7-day trapping session (Figure 3). I tested to see if my recapture rate was significantly lower than would be expected in the absence of roads using the multiple logistic regression model for translocated white-footed mice from McGregor et al. (2008; Table 1). For my purposes, I set the number of roads and traffic volume to zero in the model and obtained an expected recapture rate for my translocation distance of $114 \mathrm{~m}$. My observed recapture rate $(\sim 24 \%)$ was significantly lower than would be expected in the absence of roads (58\%) (all species: $\chi^{2}=93.45$, d.f $=1, \mathrm{P}<0.0001$; white-footed mice: $\chi^{2}=11.96$, d.f. $=1, \mathrm{P}<$ $0.001)$.

For all species combined, I found no significant relationship between the probability of a translocated individual being recaptured and median cover type (Wald $\chi^{2}$ $=0.052$, d.f. $=1, P=0.819 ;$ Figure $4 \mathrm{a})$, median width $\left(\right.$ Wald $\chi^{2}=0.176$, d.f. $=1, P=$ 0.675; Figure $4 \mathrm{~b}$ ), or their interaction (Wald $\chi^{2}=0.231$, d.f. $=1, P=0.631$ ), when 
controlling for species, sex, age class, and days remaining in the trapping session. However, the probability of recapturing a translocated individual was significantly related to species (Wald $\chi^{2}=19.494$, d.f. $=5, P=0.002$ ), age class (Wald $\chi^{2}=7.530$, d.f. $=1, \mathrm{P}=0.006)$, and days remaining in the trapping session (Wald $\chi^{2}=12.629$, d.f. $=1, \mathrm{P}$ $<0.001)$. Compared to woodland jumping mice, the odds of being recaptured were increased by a factor of 5.2 for deer mice, 3.4 for white-footed mice, and decreased by a factor of 0.66 for eastern chipmunks, 0.35 for southern red-backed voles, and $7.0 \times 10^{-9}$ for meadow jumping mice. The odds of a recapture were 9.5 times higher for adults than juveniles and increased by a factor of 1.9 for every one day increase in days remaining in the trapping session. Sex alone was not a significant predictor of recapture (Wald $\chi^{2}=$ 0.769 , d.f. $=1, P=0.381$, nor was its interaction with median width (Wald $\chi^{2}=0.929$, d.f. $=1, P=0.335)$. However, there was a significant interaction between median cover type and sex (Wald $\chi^{2}=4.709$, d.f. $=1, \mathrm{P}=0.030$ ). Specifically, females were $95 \%$ (odds ratio $=0.048$ ) less likely to be recaptured at sites with grass medians relative to treed medians.

I translocated 71 white-footed mice and recaptured 27 (38\%) (Figure 5a). There was no significant effect of median cover type (Wald $\chi^{2}=1.03 \times 10^{-4}, \mathrm{n}=71$, d.f. $=1$, $\mathrm{P}$ $=0.992)$, median width (Wald $\chi^{2}=0.339, \mathrm{n}=71$, d.f, $\left.=1, \mathrm{P}=0.561\right)$, their interaction (Wald $\chi^{2}=0.018, \mathrm{n}=71$, d.f. $\left.=1, \mathrm{P}=0.895\right)$, or $\operatorname{sex}\left(\right.$ Wald $\chi^{2}=0.426, \mathrm{n}=71$, d.f. $=1, \mathrm{P}$ $=0.514)$ on the probability of recapturing a translocated white-footed mouse. The significant interaction found between median cover type and sex when all species were combined was driven by white-footed mice, who also showed this significant interaction $\left(\right.$ Wald $\chi^{2}=5.394, \mathrm{n}=71$, d.f. $=1, \mathrm{P}=0.020$ ): translocated females were $99 \%$ (odds ratio 
$=0.009)$ less likely to be recaptured at sites with grass medians relative to treed medians

(Figure $5 b$ ). The interaction between median width and sex was marginally significant (Wald $\chi^{2}=3.008, \mathrm{n}=71$, d.f. $=1, \mathrm{P}=0.083$ ) for white-footed mice: the odds of being recaptured were 1.14 times higher for females than males for every one metre increase in median width. Age class (Wald $\chi^{2}=6.923, \mathrm{n}=71$, d.f. $=1, \mathrm{P}=0.009$ ) and the number of days remaining in the trapping session (Wald $\chi^{2}=6.266, \mathrm{n}=71$, d.f. $=1, \mathrm{P}=0.012$ ) were significant: the odds of a recapture were 25.5 times higher for adults than juveniles and increased by a factor of 1.9 for every one day increase in days remaining in the trapping session.

I translocated 71 southern red-backed voles; however, only 8 (11.3\%) were recaptured (Figure 6). With only 8 recaptures, I could not fit a full multiple logistic regression including possible confounding variables. Therefore, I only included median cover type, width, and their interaction in the model. The probability of recapturing a translocated red-backed vole was not related to median cover type $\left(\right.$ Wald $\chi^{2}=0.499, \mathrm{n}=$ 71 , d.f. $=1, \mathrm{P}=0.480$ ), median width (Wald $\chi^{2}=0.384, \mathrm{n}=71$, d.f. $=1, \mathrm{P}=0.536$ ), or the interaction between median cover type and width (Wald $\chi^{2}=0.706, \mathrm{n}=71$, d.f. $=1$, $\mathrm{P}$ $=0.401)$.

I could not statistically analyze the data for the remaining species due to low sample sizes and an inadequate number of study sites where captures occurred. Woodland jumping mice were trapped at 4 of 11 study sites, all of which had wide medians ( $>30 \mathrm{~m}$ ). In addition, approximately $70 \%$ of woodland jumping mice were trapped at one treed median site and all those that were recaptured $(n=5)$ occurred at this 
same site. Eastern chipmunks were trapped at 4 of 11 study sites, 3 of which had narrow medians $(<30 \mathrm{~m})$. Only one adult female eastern chipmunk was recaptured.

All returned individuals were recaptured within 4 days of being released, $87 \%$ within 2 days. It took significantly fewer days to recapture individuals at sites with grass medians (average $=1.15$ days), than at treed median sites (average $=1.75$ days) $(\mathrm{t}$-test with correction for unequal variance: $\mathrm{t}=2.848, \mathrm{n}=45$, d.f. $=32.127, \mathrm{P}=0.008$ ) (Figure 7). There was no significant relationship between median width and the number of days it took to recapture individuals $(\mathrm{F}=1.064, \mathrm{n}=45$, d.f. $=1, \mathrm{P}=0.308)$.

\section{Analyses of Vegetation and Traffic Volume Data}

Two sites showed no significant differences in any of the 11 vegetation variables between the two sides of the highway. Seven sites had one vegetation variable that differed significantly between the sides of the highway and two sites had two variables that differed significantly (Table 1). Given that I performed $121 \mathrm{t}$-tests, a finding of 11 significant tests is likely not a concern for my study. I found no significant relationships between any of the vegetation characteristics on the translocation side of the highway or traffic volume and median cover type or median width (Table 2).

\section{Discussion}

Neither median cover type nor width were significant main predictors of the probability of translocated small mammals returning across 4-lane highways. There have been numerous studies done on the movement of small mammals in relation to roads, but with the exception of the study by Cesarini (2007) on squirrel gliders, this study is the first to examine the effects of vegetated median features on movement across highways. 
Contrary to my predictions, reducing the forest clearance created by a 4-lane highway by having trees in the median or a narrower median width did not seem to provide an advantage over highway sections with grassy or wide medians. It is possible that some individuals may have started to cross the highway, but then remained in the median (particularly treed medians). Adams (1984) found small mammals inhabiting forested highway medians and therefore, the effect of individuals choosing to remain in the median may have counteracted any predicted increase in cross-highway movement due to reduced clearance provided by treed medians.

My study design limited, to the extent possible, potential confounding effects. I can eliminate traffic volume as a possible confounding factor in my study. Individuals were recaptured across my range of study sites, which varied in average daily traffic of 12,000 to 32,800 vehicles (Ministry of Transportation 2005). Furthermore, there were no correlations between traffic volume and median cover type or width.

Although my main predictors (median cover type and width) did not significantly affect the probability of recapturing translocated small mammals, I did find some interesting ancillary results. Specifically, the interaction between median cover type and sex was found to be a significant predictor of the probability of white-footed mice returning across the highway. Female white-footed mice were less likely to be recaptured when the median consisted of grassy vegetation, a result which may be explained by the inherent behavioural ecology of small mammals. Females must select habitat that provides safe nesting areas, whereas males, who provide little parental care, are able to seek habitats based on resource availability and mates (Morris 1984). The predominant role of females as caregivers to their young likely guides them to be more vigilant and 
selective in their movements through the landscape and they may have perceived crossing highways with grass medians as too risky. Conversely, males may be more opportunistic and willing to move through sub-optimal, open spaces due to their drive for mating opportunities and resources.

Additionally, there was a significant effect of median cover type on the return time of translocated individuals. Small mammals translocated across highway sites with grass medians took significantly fewer days to return to their point of initial capture than individuals translocated across highway sites with treed medians. The habitat preferences of forest-dependent small mammals and risk of predation in open spaces may make individuals feel vulnerable in areas that lack trees. Consequently, individuals crossing a divided highway containing a grass median, which may result in upwards of 80 to $90 \mathrm{~m}$ of total forest clearance, may do so quickly to reduce possible predation risk. On the other hand, treed medians offer protective cover and habitat for small mammals. Small mammals have been found in forested highway medians in similar densities to forests adjacent to divided highways (Adams 1984). Therefore, individuals that returned across highway sections containing treed medians may have spent time in the median, perhaps foraging, which could have resulted in longer recapture times for these individuals. Note, however, that all returning individuals were recaptured within 4 days of their translocation ( $87 \%$ within 2 days). Therefore, the slightly longer return time of animals translocated across treed median sites did not confound my main result (above).

Over $95 \%$ of recaptured individuals were adults, relative to $78 \%$ of translocated individuals that were adults. The higher return rate for adults compared to juveniles could be due to the accumulation of an individual's experience in its surroundings with age. 
Kozel and Fleharty (1979) described two types of ranges for small mammals: home range, which contains the individual's basic activities and life range or the region that contains explorations outside of the home range area. Mature small mammals will have made more exploratory excursions than juveniles, and hence, have larger life ranges. In my study, such explorations may have included previous attempts or successful crossings of the highways I studied, and therefore, the adults were less likely to be disoriented after translocation. In addition, juveniles may have low motivation to return across the highway, since they likely have not established territories at the site of their initial capture and are being stimulated to disperse by resident individuals (Gaines and McClenaghan 1980). The limited recapture of juveniles in my study is consistent with findings from other translocation studies (e.g. Bowman and Fahrig 2002; Kozel and Fleharty 1979).

There is evidence that the small mammal recaptures I detected in my study were likely not novel crossings. I found that translocated individuals were recaptured an average of 1.5 days after their release, which suggests such excursions have been performed before (Rico et al. 2007a). Furthermore, it has been suggested that some small mammals use vision to relocate their home territory when placed in unfamiliar terrain (Cooke and Terman 1977), yet vision and ability to detect forest is limited on nights with minimal moonlight (Zollner and Lima 1999). Since conditions of low moonlight illumination would have occurred throughout my field season, perhaps the individuals I recaptured (which are predominately nocturnal) had previously explored the areas where they were released and gathered visual cues during those previous excursions. As a result, 
they were able to successfully cross the highways in a short period of time during my study.

Although I translocated equal numbers of southern red-backed voles and whitefooted mice ( $n=71$ of each species), fewer southern red-backed voles were recaptured. This may suggest a species-specific response to 4-lane divided highways. This trend may be explained by differences in habitat preferences and dispersal abilities. A more generalist species, such as the white-footed mouse, will likely be less inhibited by the contrast between a forest and highway corridor compared to the red-backed vole, a forest specialist (Adams and Geis 1983; McDonald and St. Clair 2004). Furthermore, Witt and Huntly (2001) found that red-backed vole densities in isolated forest patches were negatively correlated with distance from other forest areas, whereas deer mice, a closely related species to white-footed mice, showed no such effect of increasing isolation. These results were attributed to smaller home-range sizes of red-backed voles compared to deer mice, resulting in their inability to disperse to forest patches that were more distant than their normal movement ranges. I expect that the difference in recapture rates between red-backed voles and white-footed mice in my study was the result of the stronger habitat specificity and smaller movement ranges of red-backed voles.

I provide three explanations that could potentially explain why $76 \%$ of translocated individuals were not recaptured. The first, and most likely, reason is that most of these animals simply did not attempt to cross the highways after their translocation. Second, some individuals may have crossed the highways, but were not detected. They could either have returned after the 7-day trapping session or returned during the trapping session but avoided the traps. The first of these seems unlikely to be a 
large effect since all recaptured animals were trapped within 4 days after their release and $87 \%$ were recaptured within 2 days. However, I did recapture one individual at the end of the season that was initially translocated at the beginning of the season in one of the two sites that had two trapping sessions (see Methods). It is possible that other individuals could have gone undetected in a similar manner. Third, predation on either side of the highway could have occurred before the individual had a chance to cross the highway or before it entered a trap in the trapping grid. Ermines, a common predator of small mammals, were trapped at 5 of 11 of my study sites. On one occasion, the remains of an ear-tagged white-footed mouse accompanied the ermine in the trap.

While my results suggest that highways represent significant barriers to small mammal movement, several individuals were able to cross, indicating that at least some connectivity with surrounding forest patches is maintained. This is consistent with other studies that suggest roads are only partial, not complete, barriers to small mammal movement (Goosem 2001; McDonald and St. Clair 2004; Richardson et al. 1997). Maintaining connectivity in fragmented landscapes is important for gene flow and colonization of empty habitats (Kozakiewicz 1993), which in turn, is critical for population persistence.

Although I found that small mammals were able to cross highways with vegetated medians and I did not detect any road-killed individuals at my study sites, I caution the extrapolation of my results to larger mammals. For some species, increased road permeability can result in an increased potential for road mortality due to vehicle collisions (Carr et al. 2002; Forman and Alexander 1998). Cain et al. (2003) found that maintaining the preferred habitat of bobcats in the median and along the verges of a 4- 
lane divided highway in Texas increased the likelihood of crossings, but the proportion of mortalities were also increased in these sections of the highway. Similarly, higher deer mortalities have been found where the highway median and verges provided areas for grazing (Bellis and Graves 1971). The association between road-side cover and increased highway mortality of mammals that are coyote-sized and smaller has also been shown (Clevenger et al. 2003). Therefore, the type of vegetative cover in a highway median or along the verges, may affect movement across highways by species other than those in my study.

\section{Conclusions}

My results can be generalized to conclude that highway crossings by small mammals are not strongly affected by vegetation type or width of the central median. Although previous studies have suggested that forest clearance is a central factor contributing to the barrier effect of roads on movement by forest small mammals, my findings suggest that efforts to mitigate such an effect of divided highways cannot be accomplished by altering specific median characteristics, such as vegetation type and width. Despite this, I have found that even high-traffic, multi-lane highways with vegetated medians are permeable barriers to small mammal movement. Therefore, functional connectivity may be maintained in small mammal populations next to these highways. 


\section{References}

Adams, L.W. 1984. Small mammal use of an interstate highway median strip. Journal of Applied Ecology 21:175-178.

Adams, L.W. and A.D. Geis. 1983. Effects of roads on small mammals. Journal of Applied Ecology 20:403-415.

Bellis, E.D. and H.B. Graves. 1971. Deer mortality on a Pennsylvania interstate highway. Journal of Wildlife Management 35:232-237.

Bovet, J. 1980. Homing behaviour and orientation in the red-backed vole, Clethrionomys gapperi. Canadian Journal of Zoology 58:754-760.

Bowman, J. and L. Fahrig. 2002. Gap crossing by chipmunks: an experimental test of landscape connectivity. Canadian Journal of Zoology 80:1556-1561.

Cain, A.T., V.R. Tuovila, D.G. Hewitt, and M.E. Tewes. 2003. Effects of a highway and mitigation projects on bobcats in Southern Texas. Biological Conservation 114:189-197.

Carr, L.W., L. Fahrig, and S.E. Pope. 2002. Impacts of landscape transformation by roads. Pg. 225- 243 in K.J. Gutzwiller, editor. Applying landscape ecology in biological conservation. Springer-Verlag, New York.

Cesarini, S. 2007. Major roads: a filter to the movement of the squirrel glider Petaurus Norfolcensis. Pg. 545 in Proceedings of the 2007 International Conference on Ecology and Transportation. (C.L. Irwin, D. Nelson, and K.P. McDermott, eds.). Center for Transportation and the Environment, North Carolina State University.

Clark, B.K., B.S. Clark, L.A. Johnson, and M.T. Haynie. 2001. Influence of roads on movements of small mammals. Southwestern Naturalist 46:338-344.

Clevenger, A.P., B. Chruszcz, and K.E. Gunson. 2003. Spatial patterns and factors influencing small vertebrate fauna road-kill aggregations. Biological Conservation 109:15-26.

Conrey, R. and L.S. Mills. 2001. Do highways fragment small mammal populations? Pg. 448-457 in Proceedings of the 2001 International Conference on Ecology and Transportation. (C.L. Irwin, P. Garrett, and K.P. McDermott, eds.). Center for Transportation and the Environment, North Carolina State University.

Cooke, J.A. and C.R. Terman. 1977. Influence of displacement distance and vision on homing behavior of the white-footed mouse (Peromyscus leucopus noveboracensis). Journal of Mammalogy 58:58-66. 
Darwin, A.T., D. Ladd, R. Galdins, T.A. Contreras, and L. Fahrig. 2004. Response of forest understory vegetation to a major ice storm. Journal of the Torrey Botanical Society 131:45-52.

Ford, A.T. and L. Fahrig. 2008. Movement patterns of eastern chipmunks (Tamias striatus) near roads. Journal of Mammalogy 89:895-903.

Forman, R.T.T. and L.E. Alexander. 1998. Roads and their major ecological effects. Annual Review of Ecology and Systematics 29:207-231.

Gaines, M.S. and L.R. McClenaghan. 1980. Dispersal in small mammals. Annual Review of Ecology and Systematics 11:163-196.

Garland, T. and W.G. Bradley. 1984. Effects of a highway on Mojave Desert rodent populations. American Midland Naturalist 111:47-56.

Goosem, M. 2001. Effects of tropical rainforest roads on small mammals: inhibition of crossing movements. Wildlife Research 28:351-364.

Goosem, M. 2002. Effects of tropical rainforest roads on small mammals: fragmentation, edge effects and traffic disturbance. Wildlife Research 29:277-289.

Goosem, M. and H. Marsh. 1997. Fragmentation of a small-mammal community by a powerline corridor through tropical rainforest. Wildlife Research 24:613-629.

Henein, K.M. 1995. Predicting the survival of woodland species in human-altered landscapes. Ph.D. Thesis, Carleton University.

Jaegar, J.A.G., J. Bowman, J. Brennan, L. Fahrig, D. Bert, J. Bouchard, N. Charbonneau, K. Frank, B. Gruber, K. Tluk von Toschanowitz. 2005. Predicting when animal populations are at risk from roads: an interactive model of road avoidance behavior. Ecological Modelling 185:329-348.

Kociolek, A. and A.P. Clevenger. 2007. Pg. 609-612 in Proceedings of the 2007 International Conference on Ecology and Transportation. (C.L. Irwin, D. Nelson, and K.P. McDermott, eds.). Center for Transportation and the Environment, North Carolina State University.

Kozakiewicz, M. 1993. Habitat isolation and ecological barriers-the effect on small mammal populations and communities. Acta Theriologica 38:1-30.

Kozel, R.M. and E.D. Fleharty. 1979. Movements of rodents across roads. Southwestern Naturalist 24:239-248.

Krohne, D.T. and G.A. Hoch. 1999. Demography of Peromyscus leucopus populations on habitat patches: the role of dispersal. Canadian Journal of Zoology 77:1247-1253. 
Lima, S.L. and P.A. Zollner. 1996. Towards a behavioral ecology of ecological landscapes. Trends in Ecology \& Evolution 11:131-135.

Mader, H.J. 1984. Animal habitat isolation by roads and agricultural fields. Biological Conservation 29:81-96.

Maier, T.J. 2002. Long-distance movements by female White-footed Mice, Peromyscus leucopus, in extensive mixed-wood forest. Canadian Field-Naturalist 116:108111.

McDonald, W.R. and C.C. St. Clair. 2004. The effects of artificial and natural barriers on the movement of small mammals in Banff National Park, Canada. Oikos 105:397407.

McGregor, R.L., D.J. Bender, and L. Fahrig. 2008. Do small mammals avoid roads because of the traffic? Journal of Applied Ecology 45:117-123.

Ministry of Transportation. 2005. Provincial Highways Traffic Volumes 2005 (AADT Only). Annual publication. Traffic Office, Ministry of Transportation, Ontario.

Morris, D.W. 1984. Sexual differences in habitat use by small mammals: evolutionary strategy or reproductive constraint? Oecologia 65:51-57.

Murie, O.J. and A. Murie. 1931. Travels of Peromyscus. Journal of Mammalogy 12:200209.

Oxley, D.J., M.B. Fenton, and G.R. Carmody. 1974. The effects of roads on populations of small mammals. Journal of Applied Ecology 11:51-59.

Pidduck, E.R. and J.B. Falls. 1973. Reproduction and emergence of juveniles in Tamias striatus (Rodentia: Sciuridae) at two localities in Ontario, Canada. Journal of Mammalogy 54:693-707.

Richardson, J.H., R.F. Shore, and J.R. Treweek. 1997. Are major roads a barrier to small mammals? Journal of Zoology 243:840-846.

Rico, A., P. Kindlmann, and F. Sedlacek. 2007a. Road crossing in bank voles and yellownecked mice. Acta Theriologica 52:85-94.

Rico, A., P. Kindlmann, and F. Sedlacek. 2007b. Barrier effects of roads on movements of small mammals. Folia Zoologica 56:1-12. 
Roberts-Pichette, P. and L. Gillespie. 1999. Terrestrial vegetation biodiversity monitoring protocols. Ecological Monitoring and Assessment Network (EMAN) Occasional Paper Series, Report No. 9. Ecological Monitoring and Assessment Network Coordinating Office, Environment Canada.

Rondinini, C. and C.P. Doncaster. 2002. Roads as barriers to movement for hedgehogs. Functional Ecology 16:504-509.

Root, J.J., C.H. Calisher, and B.J. Beaty. 1999. Relationships of deer mouse movement, vegetative structure, and prevalence of infection with Sin Nombre virus. Journal of Wildlife Diseases 35:311-318.

Sare, D.T.J., J.S. Millar, and F.J. Longstaffe. 2005. Moulting patterns in Clethrionomys gapperi. Acta Theriologica 50:561-569.

Schreiber, R.K. and J.H. Graves. 1977. Powerline corridors as possible barriers to the movements of small mammals. American Midland Naturalist 97:504-508.

Seidel, D.R. 1961. Homing in the eastern chipmunk. Journal of Mammalogy 42:256-257.

Waite, S. 2000. Statistical ecology in practice: a guide to analysing environmental and ecological field data. Prentice Hall, London, UK.

Whitaker, J.O. 1972. Zapus hudsonius. Mammalian Species 11:1-7.

Whitaker, J.O. and R.E. Wrigley. 1972. Napaeozapus insignis. Mammalian Species 14:16.

Wilkins, K.T. 1982. Highways as barriers to rodent dispersal. Southwestern Naturalist $27: 459-460$.

Witt, W.C. and N. Huntly. 2001. Effects of isolation on red-backed voles (Clethrionomys gapperi) and deer mice (Peromyscus maniculatus) in a sage-steppe matrix. Canadian Journal of Zoology 79:1597-1603.

Zollner, P.A. 2000. Comparing the landscape level perceptual abilities of forest sciurids in fragmented agricultural landscapes. Landscape Ecology 15:523-533.

Zollner, P.A. and K.J. Crane. 2003. Influence of canopy closure and shrub coverage on travel along coarse woody debris by eastern chipmunks (Tamias striatus). American Midland Naturalist 150:151-157.

Zollner, P.A. and S.L. Lima. 1999. Illumination and the perception of remote habitat patches by white-footed mice. Animal Behaviour 58:489-500. 


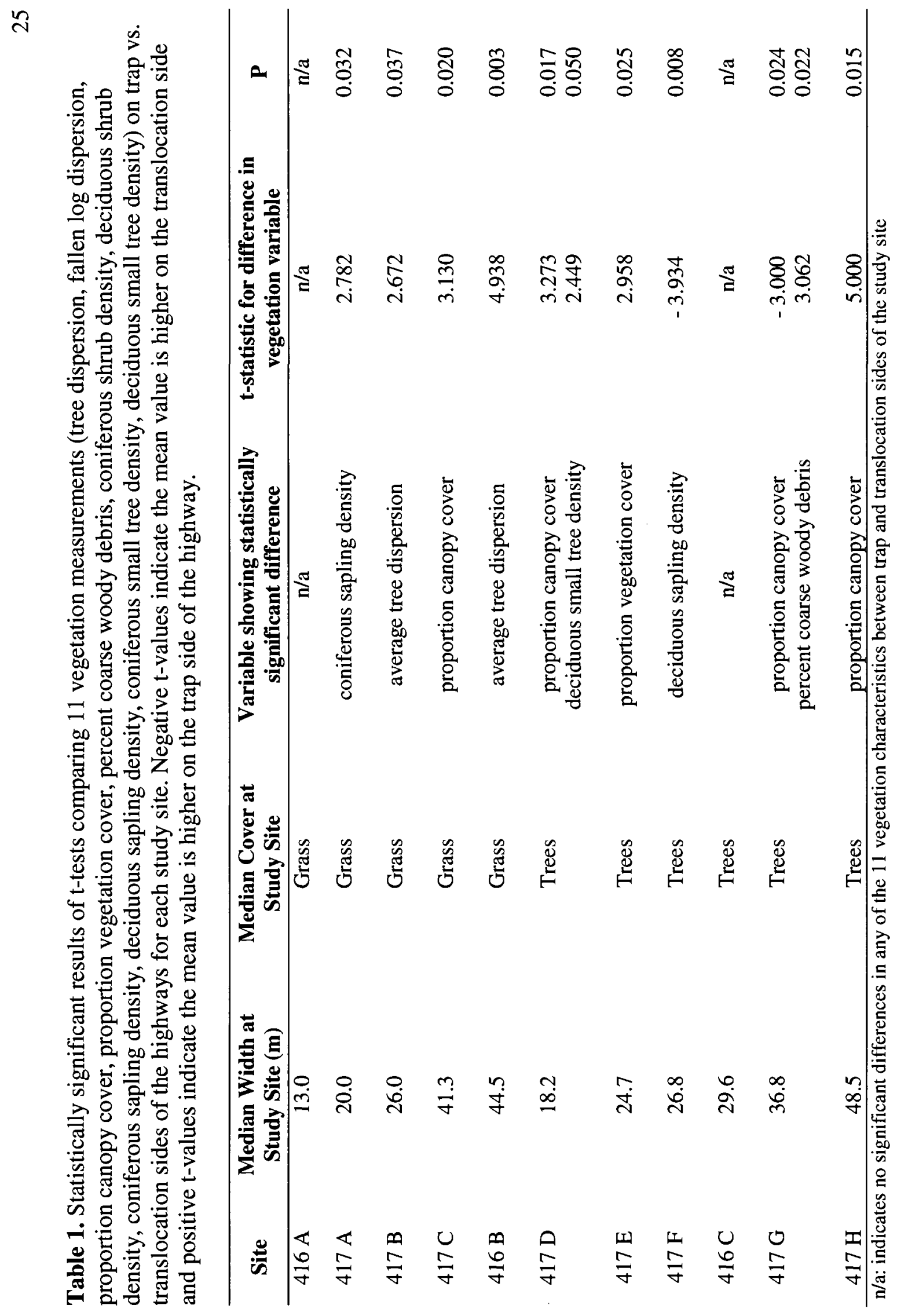


Table 2. Comparisons of median cover type and width to Annual Average Daily Traffic (AADT) and 11 vegetation characteristics on the translocation side of the 11 study sites. T-tests were performed to test for relationships with median cover type and regression analyses for relationships with median width. T-statistics represent the difference in the mean value of the variable at sites with grass medians and the mean value of the variable at sites with treed medians.

\begin{tabular}{|c|c|c|c|c|c|}
\hline \multirow[t]{3}{*}{ Response } & \multicolumn{5}{|c|}{ Predictor } \\
\hline & \multicolumn{2}{|c|}{ median cover } & \multicolumn{3}{|c|}{ median width } \\
\hline & t-statistic & $\mathbf{P}$ & $\begin{array}{c}\text { Standardized } \\
\beta \\
\end{array}$ & $\begin{array}{c}\text { F- } \\
\text { statistic }\end{array}$ & $P$ \\
\hline \multicolumn{6}{|l|}{ (a) Traffic variable } \\
\hline AADT & -0.355 & 0.731 & -0.272 & 0.719 & 0.418 \\
\hline \multicolumn{6}{|l|}{ (b) Vegetation variables } \\
\hline Tree dispersion & -0.618 & 0.552 & -0.266 & 0.686 & 0.429 \\
\hline Fallen log dispersion & 0.436 & 0.673 & -0.240 & 0.548 & 0.478 \\
\hline Proportion canopy cover & -0.584 & 0.580 & -0.063 & 0.036 & 0.853 \\
\hline Proportion vegetation cover & 0.836 & 0.425 & 0.330 & 1.097 & 0.322 \\
\hline Percent coarse woody debris & -1.278 & 0.233 & -0.333 & 1.125 & 0.316 \\
\hline Coniferous shrub density & -1.000 & 0.363 & 0.538 & 3.674 & 0.087 \\
\hline Deciduous shrub density & 1.933 & 0.085 & -0.194 & 0.354 & 0.567 \\
\hline Coniferous sapling density & -0.742 & 0.477 & -0.166 & 0.254 & 0.626 \\
\hline Deciduous sapling density & -0.138 & 0.894 & 0.100 & 0.091 & 0.770 \\
\hline Coniferous small tree density & -1.329 & 0.238 & -0.025 & 0.006 & 0.942 \\
\hline Deciduous small tree density & 0.564 & 0.587 & 0.540 & 3.696 & 0.087 \\
\hline
\end{tabular}




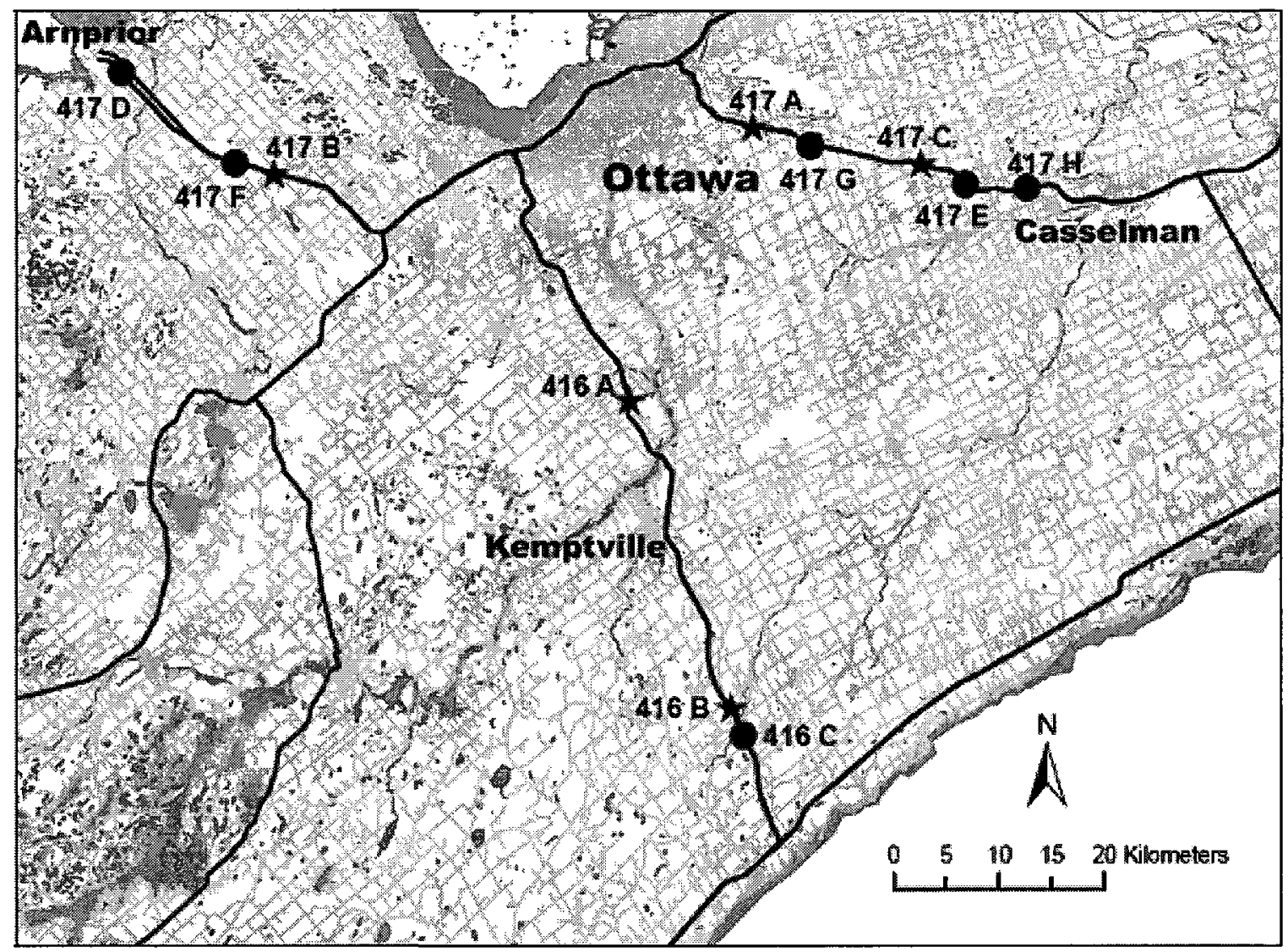

Figure 1. Locations of 11 study sites along two 4-lane divided highways (Hwy 416 and $417)$ in the Ottawa region. Symbols represent the type of vegetation in the median at each study site ( $\downarrow=$ grass median; $\mathbf{O}=$ treed median). 


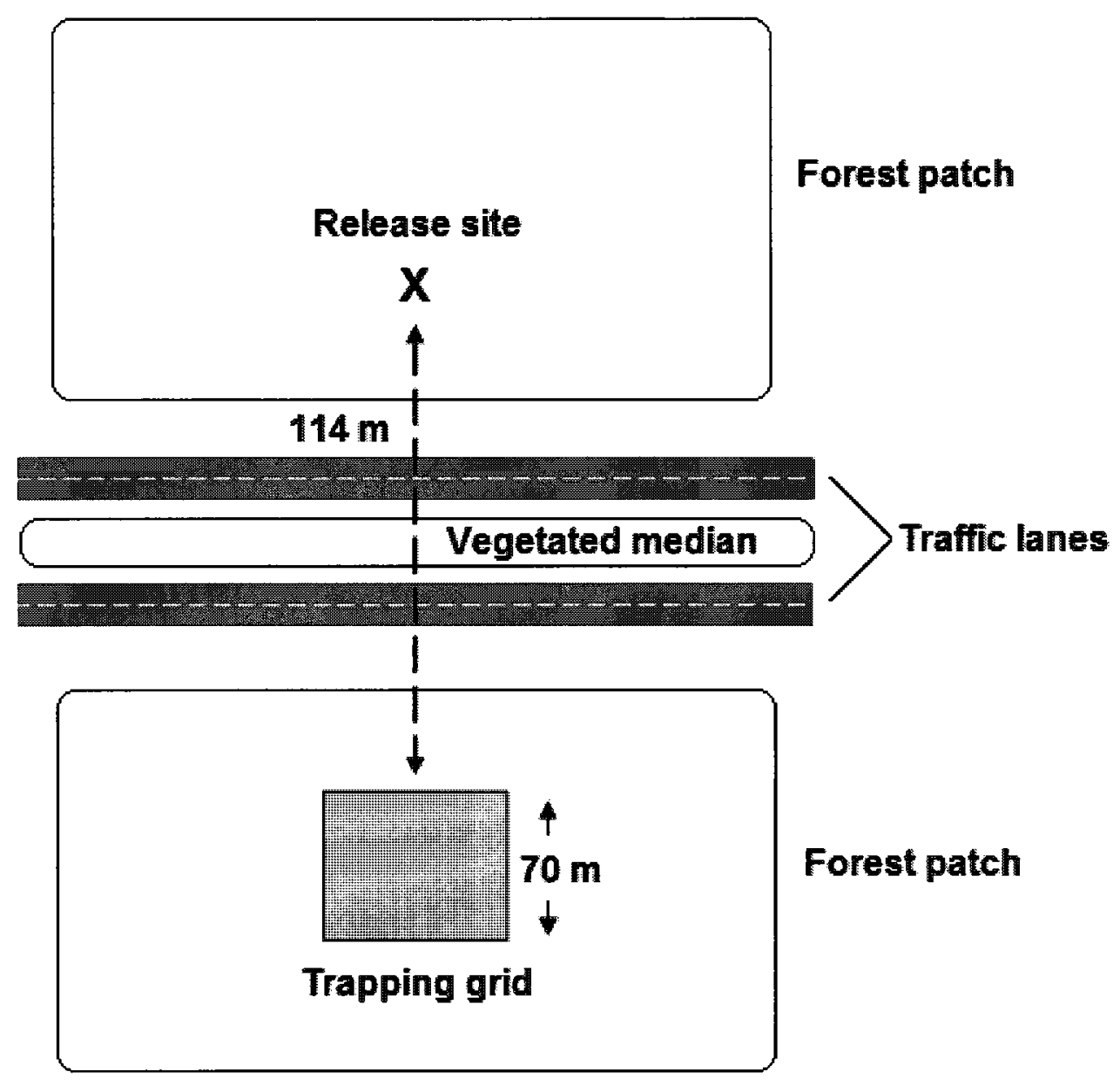

Figure 2. Illustration of a study site showing trapping grid on one side of highway and release location on other side. Total linear translocation distance from edge of trapping grid to release site was $114 \mathrm{~m}$ for all 11 sites. 


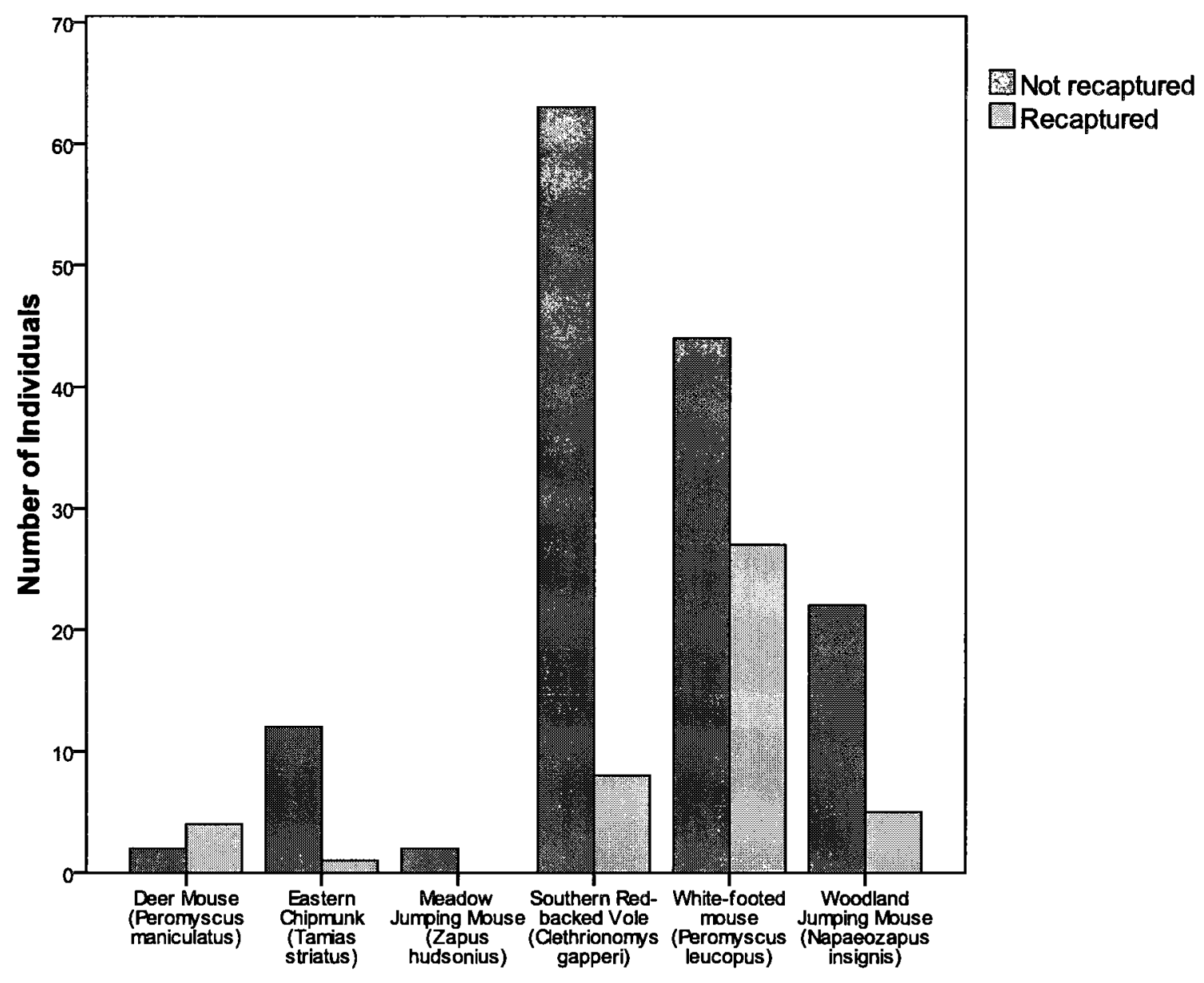

Figure 3. Number of individuals of 6 small mammal species that were recaptured (light bars) or not recaptured (dark bars) after translocation across 4-lane divided highways containing a central vegetated median at 11 study sites. 


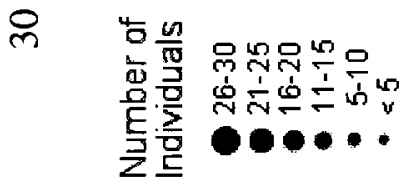
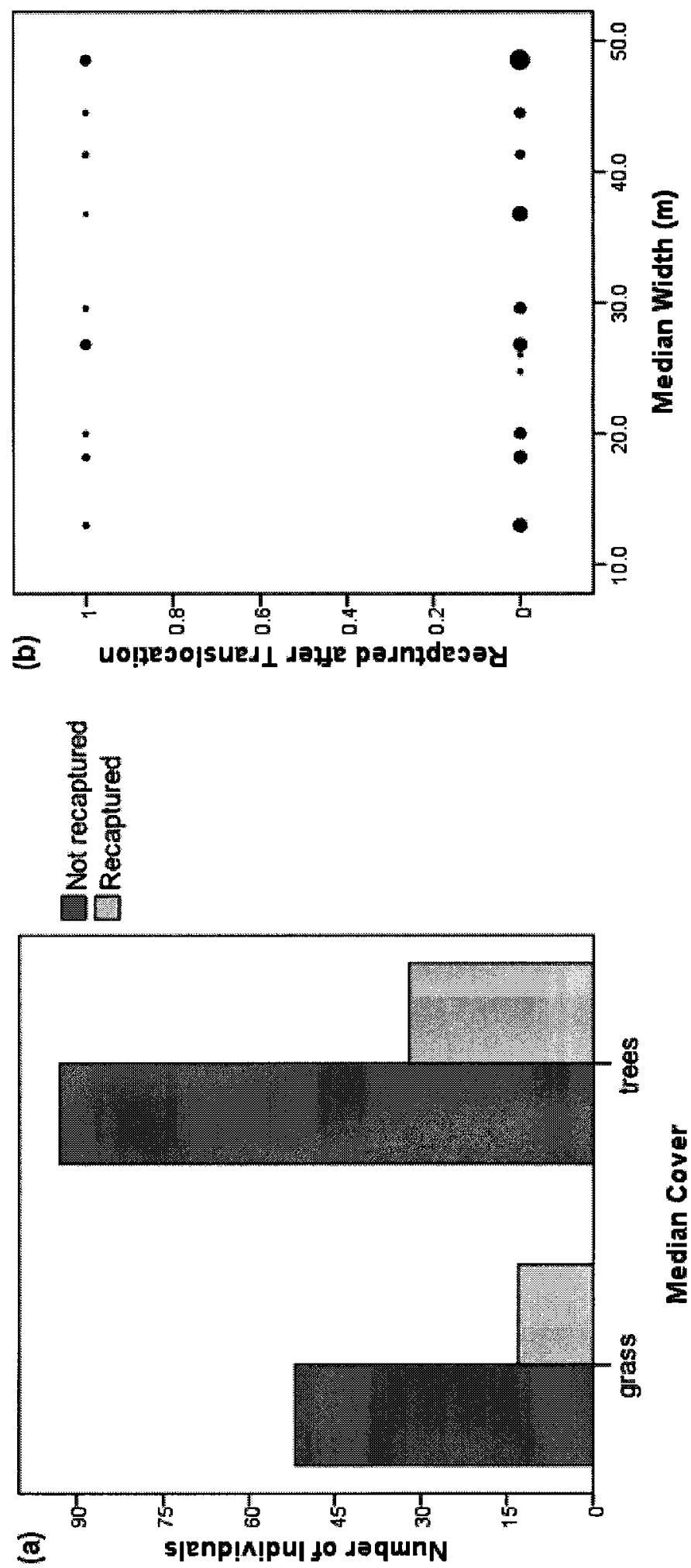

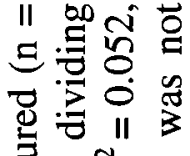

출 적

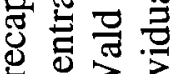

월

总艾卷

วัธ

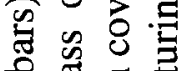

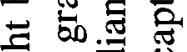

$\because$ on

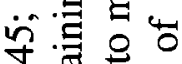

॥ 节总

ㄷㅇㅇㅠ

马结

总充음

음

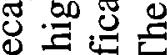

承.

$\stackrel{0}{0} \dot{0}$

过

क 5 虽

폴을

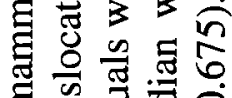

흥

元士

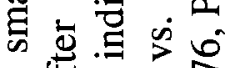

6 焉市

ப

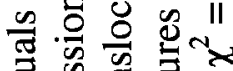

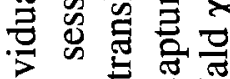

: 00 \%

$\exists . \Xi$

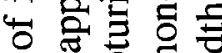

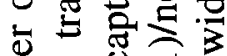

거요

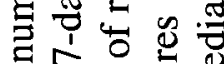

o 00.

.. $\bar{\Xi}$

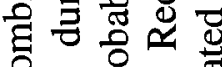

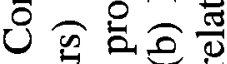

ฮิ

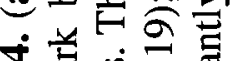

४ तुํㅁ

ํ. 웡

. 


$$
\text { क }
$$
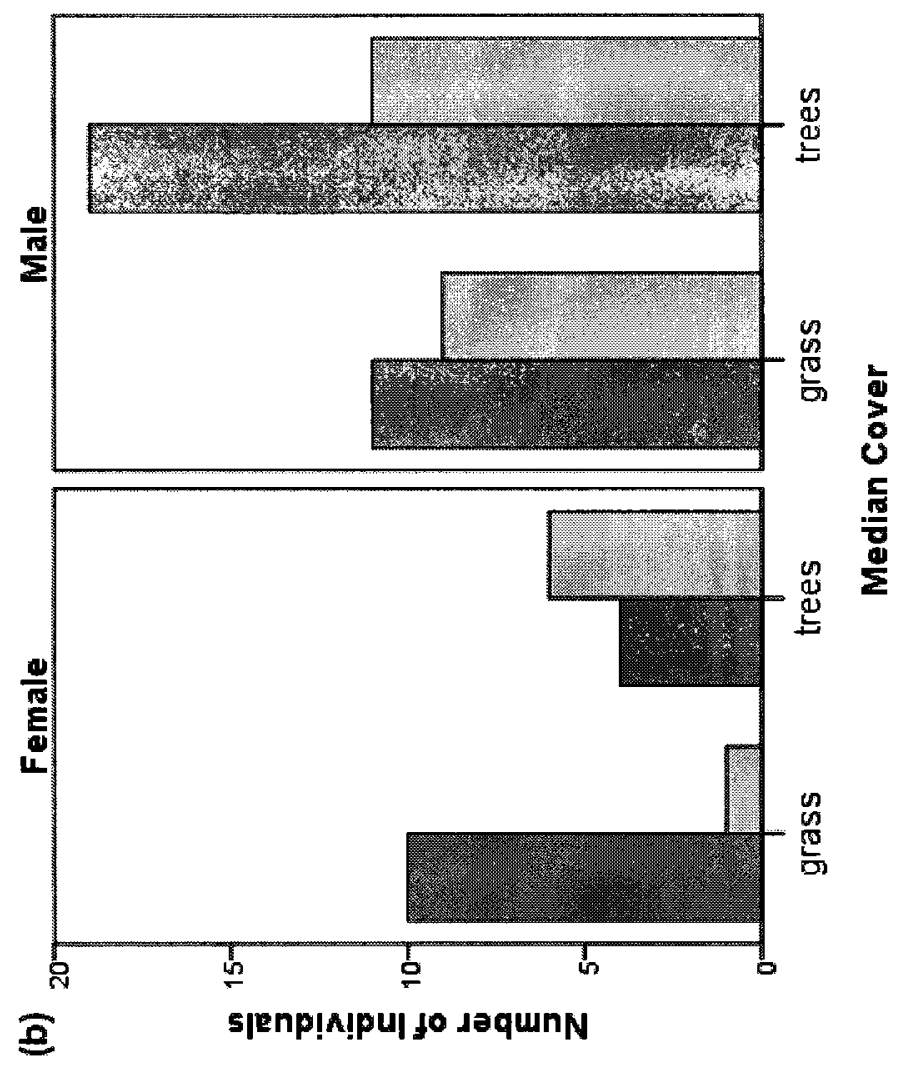

8

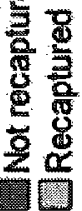

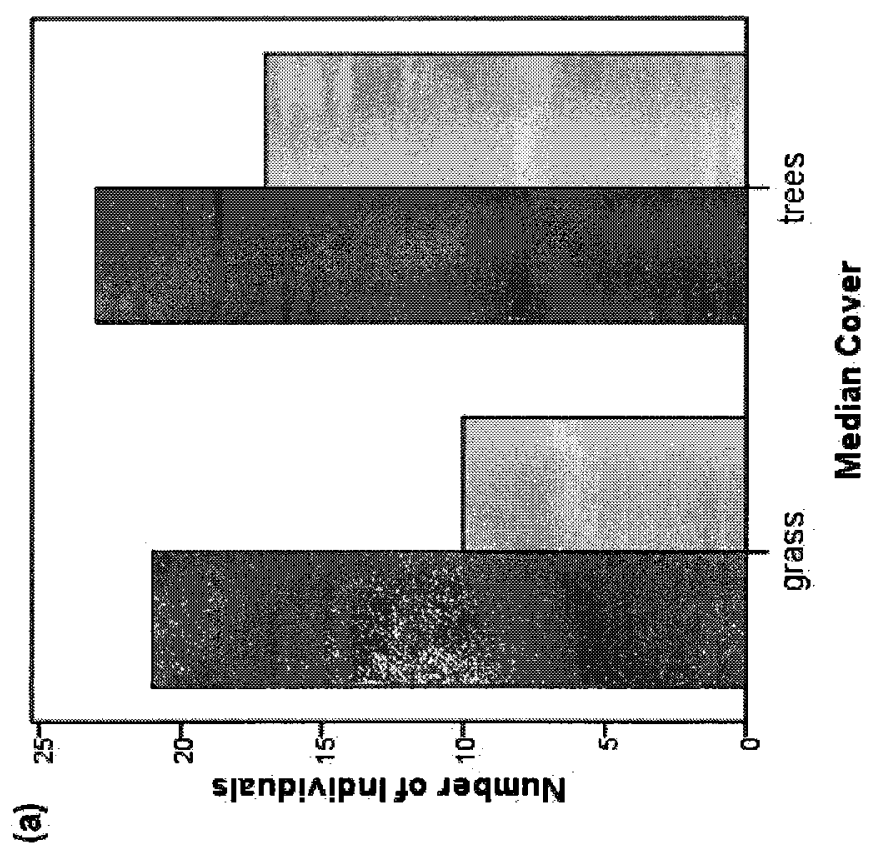

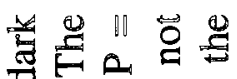

莳突它完

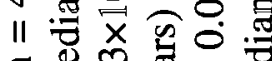

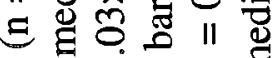

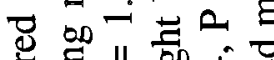

矛

局: 을 总

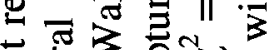

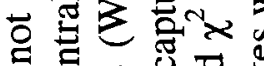

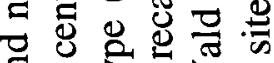

宁全定

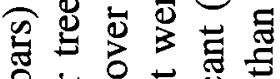

ㄴㅇㅇ용

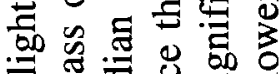

‥

خิ

I.

ㅌ. 명

ठ

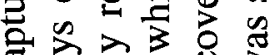

정 증

ญ

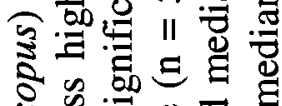

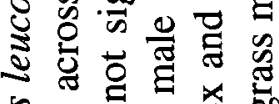

ร

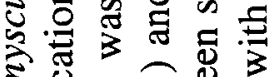

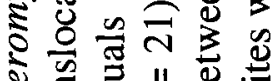

बे है

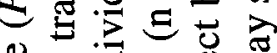

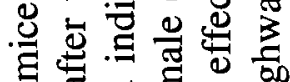

छ

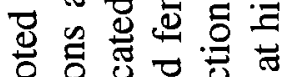

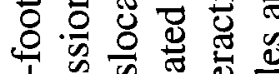

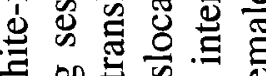

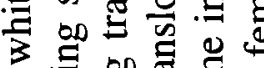

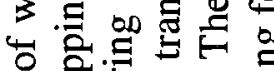

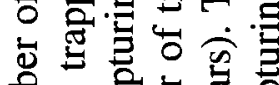

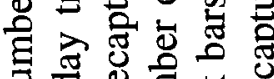

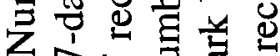

ชิ

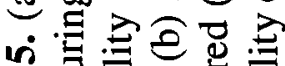

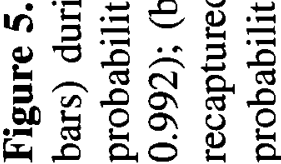




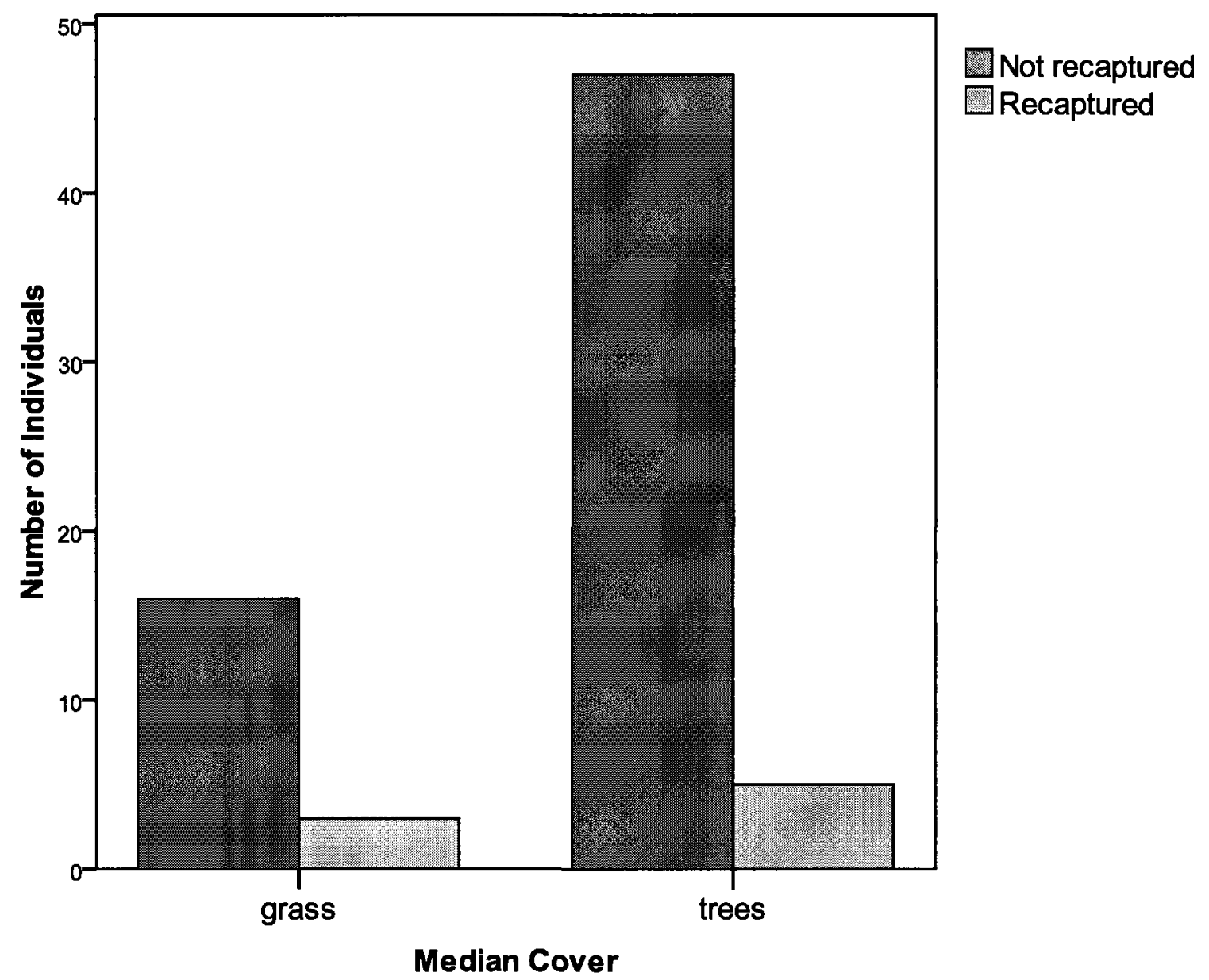

Figure 6. Number of southern red-backed voles (Clethrionomys gapperi) that were recaptured ( $n=8$; light bars) and not recaptured $(n=63$; dark bars) during 7-day trapping sessions after translocation across highways containing grass or treed central dividing medians. The probability of recapturing translocated individuals was not significantly related to median cover type (Wald $\chi^{2}=0.499, \mathrm{P}=0.480$ ). 


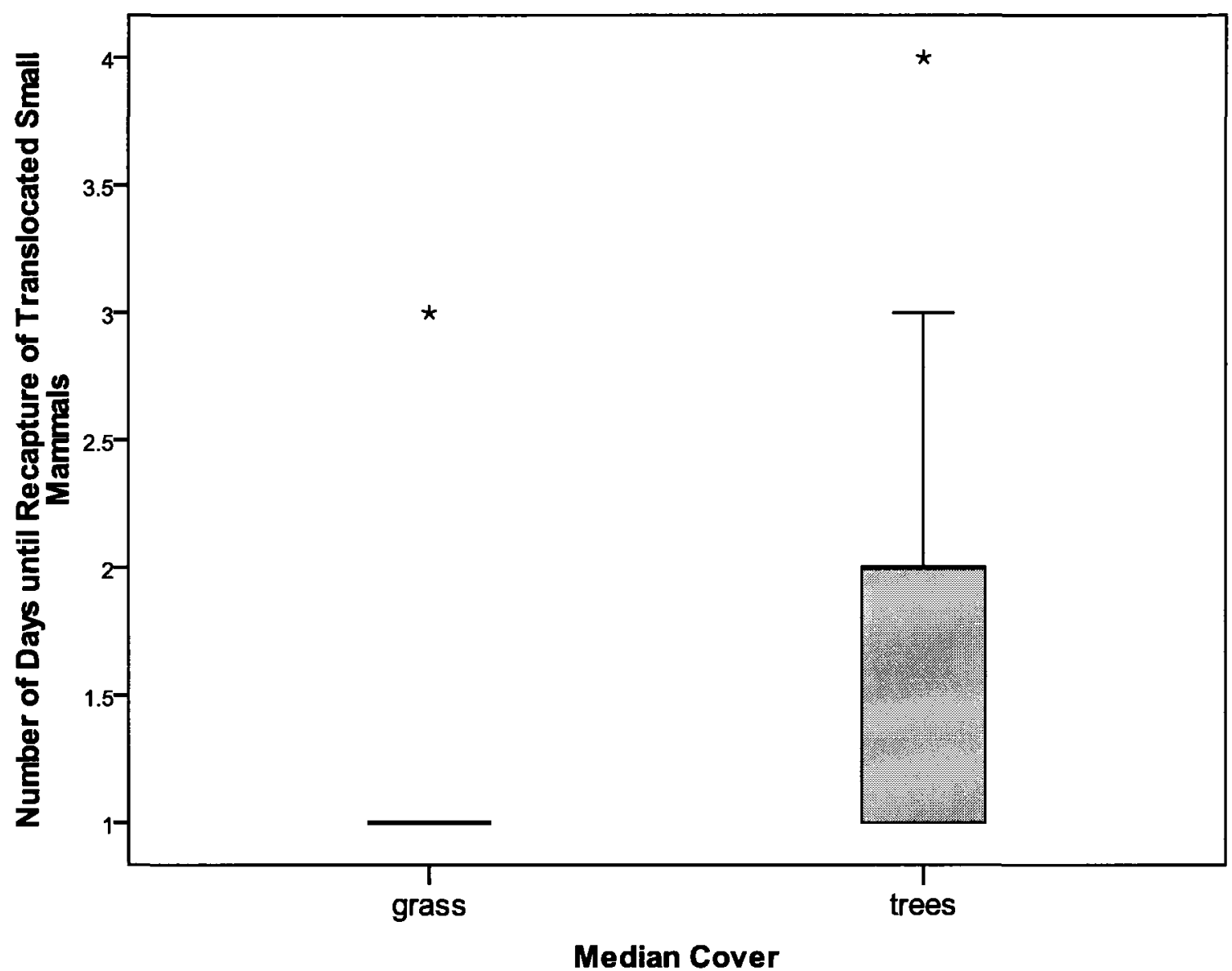

Figure 7. Boxplots (categorized by median cover type) showing the number of days during 7-day trapping sessions that it took to recapture the 45 of 190 small mammals that were translocated across divided highways $(\mathrm{t}=2.848 ; \mathrm{n}$ (grass) $=13, \mathrm{n}$ (trees) $=32 ; \mathrm{P}=$ 0.008). All individuals at grass median sites were recaptured within 1 day after translocation, except one individual that was recaptured after 3 days $\left(^{*}\right)$. At the treed median sites, the median number of days for recapture was 2 and the maximum was 4 days $\left(^{*}\right)$. 
Appendix A. Results of multiple logistic regression analyses for (a) all species combined, (b) Peromyscus leucopus, and (c) Clethrionomys gapperi on the relationship between the probability of recapturing translocated individuals and median cover type, median width, median cover type $x$ width (main predictors), species, sex, age class, days remaining in trapping session (confounding variables), and interactions of sex with median cover type and width.

\begin{tabular}{lrrr}
\hline Parameter & Estimate & Wald $\chi^{2}$ & P \\
\hline (a) All species & & & \\
Intercept & -5.955 & 10.467 & 0.001 \\
Median cover (grass) & -0.324 & 0.052 & 0.819 \\
Median width & 0.013 & 0.176 & 0.675 \\
Species & -- & 19.494 & 0.002 \\
Peromyscus maniculatus & 1.654 & 1.570 & 0.210 \\
Tamias striatus & -0.410 & 0.078 & 0.779 \\
Zapus hudsonius & -18.724 & 0.000 & 0.999 \\
Clethrionomys gapperi & -1.060 & 1.537 & 0.215 \\
Peromyscus leucopus & 1.233 & 2.085 & 0.149 \\
Napaeozapus insignis (reference) & -- & -- & -- \\
Sex (female) & 1.418 & 0.769 & 0.381 \\
Age class (adult) & 2.255 & 7.530 & 0.006 \\
Days remaining in trapping session & 0.649 & 12.629 & $<0.001$ \\
Median cover (grass) $\times$ Median width & 0.020 & 0.231 & 0.631 \\
Median cover (grass) $\times$ Sex (female) & -3.030 & 4.709 & 0.030 \\
Median width $\times$ Sex (female) & -0.044 & 0.929 & 0.335 \\
(b) Peromyscus leucopus & & & \\
Intercept & & & \\
Median cover (grass) & -4.763 & 6.013 & 0.014 \\
Median width & -0.018 & $1.03 \times 10^{-4}$ & 0.992 \\
Sex (female) & -0.023 & 0.339 & 0.561 \\
Age class (adult) & -1.565 & 0.426 & 0.514 \\
Days remaining in trapping session & 3.240 & 6.923 & 0.009 \\
Median cover (grass) $\times$ Median width & 0.655 & 6.266 & 0.012 \\
Median cover (grass) $\times$ Sex (female) & 0.007 & 0.018 & 0.895 \\
Median width $\times$ Sex (female) & -4.693 & 5.394 & 0.020 \\
\hline & 0.133 & 3.008 & 0.083 \\
\hline
\end{tabular}


Appendix A. (continued)

\begin{tabular}{llll}
\hline Parameter & Estimate & Wald $\chi^{2}$ & $\mathbf{P}$ \\
\hline
\end{tabular}

(c) Clethrionomys gapperi

\begin{tabular}{lccc} 
Intercept & -3.419 & 2.890 & 0.089 \\
Median cover (grass) & -4.274 & 0.499 & 0.480 \\
Median width & 0.035 & 0.384 & 0.536 \\
Median cover (grass) $\times$ Median width & 0.123 & 0.706 & 0.401 \\
\hline
\end{tabular}

Note: parameter estimates for categorical variables are relative to reference levels (lowest level of each variable) 
Appendix B. Locations of the 11 highway study sites used for trapping and translocation of small mammals near Ottawa, Ontario (NAD 1983 UTM Zone 18N).

\begin{tabular}{ccccc}
\hline Site & Median Width (m) & Median Cover & Easting (m) & Northing (m) \\
\hline & & & & \\
416 A & 13.0 & Grass & 446917.7849 & 4997621.9684 \\
417 A & 20.0 & Grass & 458620.2723 & 5023887.0031 \\
417 B & 26.0 & Grass & 413171.2909 & 5019365.5246 \\
417 C & 41.3 & Grass & 474606.6230 & 5020336.8305 \\
416 B & 44.5 & Grass & 456636.5716 & 4968016.0987 \\
417 D & 18.2 & Trees & 398797.0830 & 5028983.7326 \\
417 E & 24.7 & Trees & 478917.6617 & 5018268.4587 \\
417 F & 26.8 & Trees & 409605.6483 & 5020370.1550 \\
416 C & 29.6 & Trees & 457873.4339 & 4965410.1813 \\
417 G & 36.8 & Trees & 464184.3334 & 5022092.1103 \\
417 H & 48.5 & Trees & 484708.7605 & 5017908.9521 \\
\hline
\end{tabular}


Appemdlix $\mathbb{C}_{0}$ 1. Example of a 4-lane divided highway study site with a grass median (aerial and road-side images).

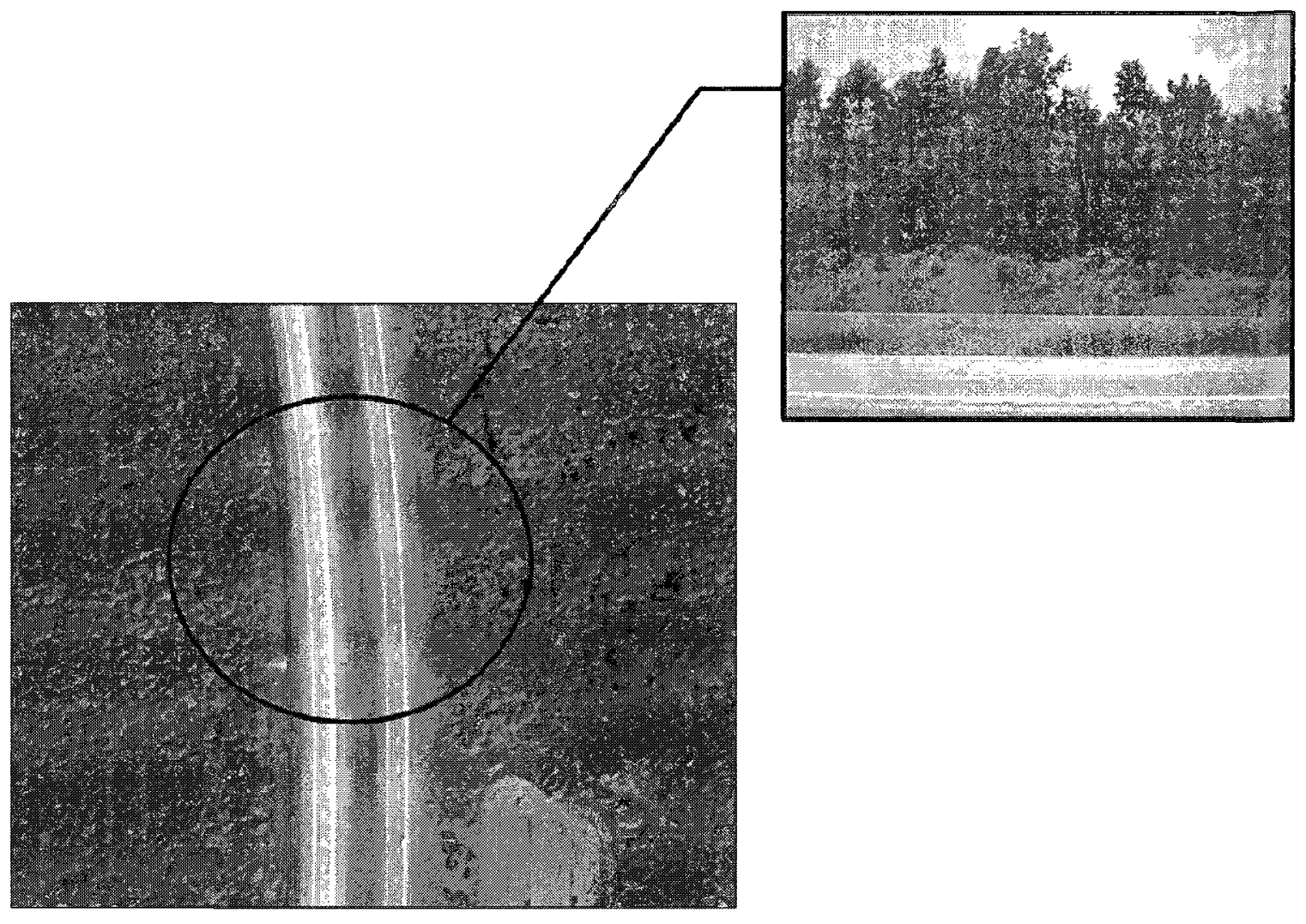


Appendlix $\mathbb{C}$.2. Example of a 4-lane divided highway study site with a treed median (aerial and road-side images).

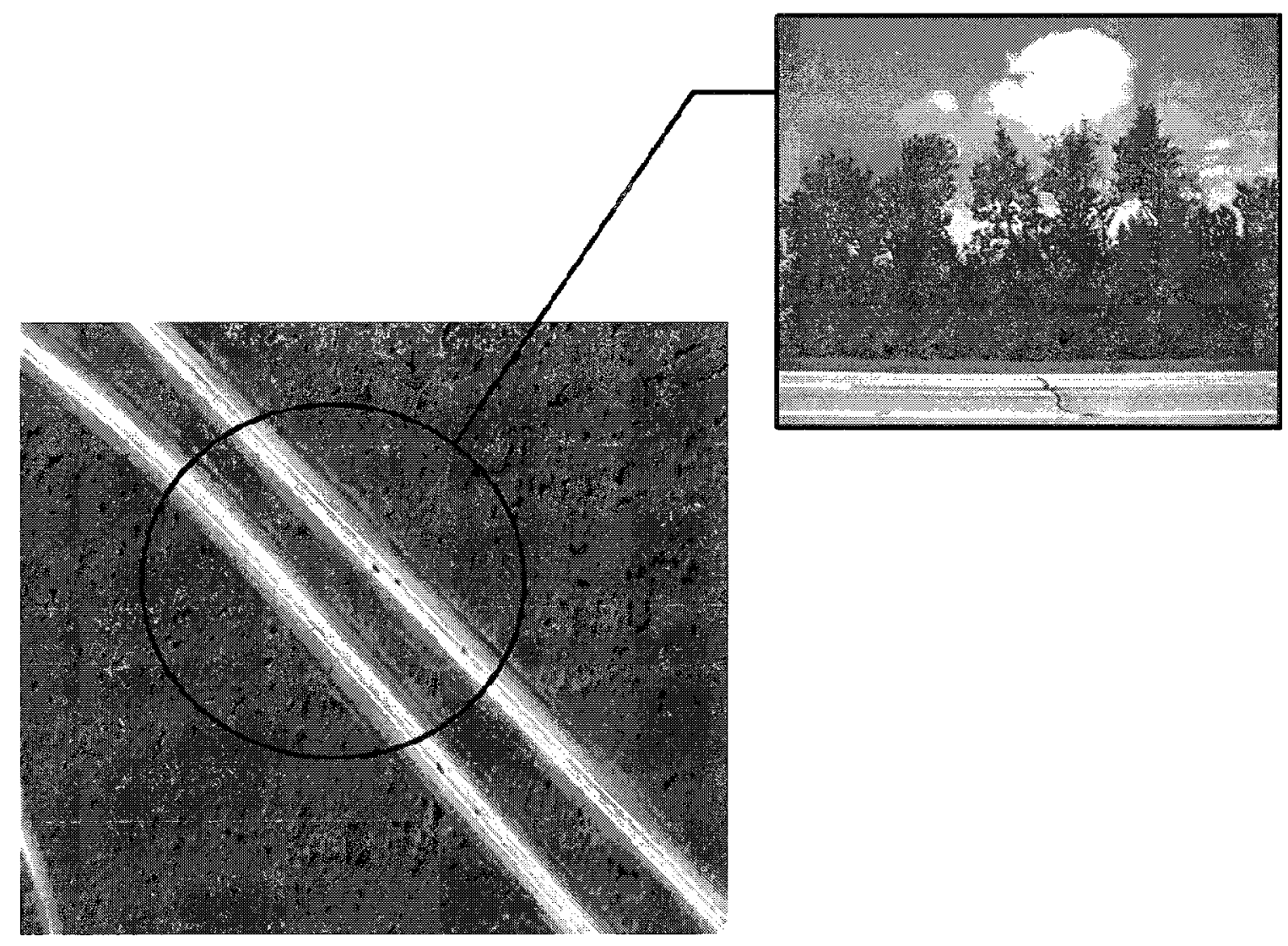


Appendix D. Definitions of juvenile, sub-adult, and adult age classes used to categorize individuals of 6 small mammal species translocated across 11 highway study sites.

\begin{tabular}{|c|c|c|c|c|}
\hline Species & JUVENILE & $\begin{array}{r}\text { Age class } \\
\text { SUB-ADULT }\end{array}$ & ADULT & Reference \\
\hline Peromyscus leucopus & $\begin{array}{l}<16 \text { g; gray } \\
\text { pelage }\end{array}$ & $\begin{array}{l}16-18 \mathrm{~g} ; \\
\text { molting gray } \\
\text { to brown }\end{array}$ & $\begin{array}{l}>18 \mathrm{~g} ; \text { brown } \\
\text { pelage }\end{array}$ & $\begin{array}{l}\text { Krohne and } \\
\text { Hoch } 1999\end{array}$ \\
\hline Peromyscus maniculatus & \multicolumn{3}{|c|}{$\begin{array}{l}\text { similar mass classifications used as } P \text {. } \\
\text { leucopus; distinguished by sharply bicoloured } \\
\text { tail and large ears }\end{array}$} & $\begin{array}{l}\text { Root et al. } \\
1999 \text { (mass } \\
\text { estimates) }\end{array}$ \\
\hline Clethrionomys gapperi & $\begin{array}{l}<13 \mathrm{~g} \text {; dark } \\
\text { brown }\end{array}$ & $\begin{array}{l}13-16 \mathrm{~g} \\
\text { mottled } \\
\text { brown or } \\
\text { light brown }\end{array}$ & $\begin{array}{l}>16 \mathrm{~g} ; \text { brown } \\
\text { with red dorsal } \\
\text { stripe }\end{array}$ & $\begin{array}{l}\text { Sare et al. } \\
2005\end{array}$ \\
\hline Napaeozapus insignis & $\begin{array}{l}<14 \mathrm{~g} \\
\text { yellow- } \\
\text { brown sides }\end{array}$ & $14-17 \mathrm{~g}$ & $\begin{array}{l}>17 \mathrm{~g} \text {; brown } \\
\text { or black dorsal } \\
\text { stripe, orange- } \\
\text { brown sides }\end{array}$ & $\begin{array}{l}\text { Whitaker } \\
\text { and } \\
\text { Wrigley } \\
1972\end{array}$ \\
\hline Zapus hudsonius & \multicolumn{3}{|c|}{$\begin{array}{l}\text { similar mass classification used as } N \text {. insignis; } \\
\text { darker in colour than } N \text {. insignis and no } \\
\text { white-tipped tail }\end{array}$} & $\begin{array}{l}\text { Whitaker } \\
1972\end{array}$ \\
\hline Tamias striatus & $\begin{array}{l}<85 \mathrm{~g} \text {; non- } \\
\text { reproductive }\end{array}$ & $\begin{array}{l}85-100 \mathrm{~g} ; \\
\text { July or later } \\
\text { capture }\end{array}$ & $\begin{array}{l}>100 \mathrm{~g}, \\
\text { obvious } \\
\text { breeding } \\
\text { condition or at } \\
\text { least } 85 \mathrm{~g} \text { and } \\
\text { first captured } \\
\text { in May or } \\
\text { June }\end{array}$ & $\begin{array}{l}\text { Pidduck } \\
\text { and Falls } \\
1973 ; \\
\text { Henein } \\
1995\end{array}$ \\
\hline
\end{tabular}


Appendix E. Vegetation definitions (dominant tree species, coarse woody debris, fallen log, non-woody vegetation cover, shrubs, saplings, small trees) used during vegetation data collection in $10 \times 10 \mathrm{~m}$ plots at the trap and translocation sides of each highway study site.

\begin{tabular}{|c|c|c|}
\hline Vegetation Variable & Definition & Reference \\
\hline $\begin{array}{l}\text { Dominant tree species (used } \\
\text { in measurement of tree } \\
\text { dispersion) }\end{array}$ & $\begin{array}{l}\text { trees with diameter at } \\
\text { breast height }(\mathrm{DBH})>10.0 \\
\mathrm{~cm}\end{array}$ & Darwin et al. 2004 \\
\hline Coarse woody debris & $\begin{array}{l}>5 \mathrm{~cm} \text { in length, }>2.0 \mathrm{~cm} \\
\text { diameter }\end{array}$ & $\begin{array}{l}\text { Zollner and Crane } \\
2003 \text {; Darwin et al. } \\
2004\end{array}$ \\
\hline $\begin{array}{l}\text { Fallen log (used in } \\
\text { measurement of dispersion) }\end{array}$ & $\operatorname{logs} \geq 2.0 \mathrm{~cm}$ in diameter & $\begin{array}{l}\text { Zollner and Crane } \\
2003\end{array}$ \\
\hline Non-woody vegetation cover & $\begin{array}{l}>5 \mathrm{~cm} \text { but } \leq 100 \mathrm{~cm} \text { in } \\
\text { height }\end{array}$ & $\mathrm{n} / \mathrm{a}$ \\
\hline Shrubs & $\begin{array}{l}\text { DBH }<4.0 \mathrm{~cm} \text {; multi- } \\
\text { stemmed woody plants } \\
\text { with most stems originating } \\
\text { at or near the ground }\end{array}$ & $\begin{array}{l}\text { Roberts-Pichette and } \\
\text { Gillespie } 1999\end{array}$ \\
\hline Saplings & $\begin{array}{l}<4.0 \mathrm{~cm} \text { DBH; single- } \\
\text { stemmed woody plants }\end{array}$ & $\begin{array}{l}\text { Roberts-Pichette and } \\
\text { Gillespie } 1999\end{array}$ \\
\hline Small trees & $\begin{array}{l}\geq 4.0 \mathrm{~cm} \text { but }<10.0 \mathrm{~cm} \\
\mathrm{DBH} ; \text { single-stemmed } \\
\text { woody plants }\end{array}$ & $\begin{array}{l}\text { Roberts-Pichette and } \\
\text { Gillespie } 1999\end{array}$ \\
\hline
\end{tabular}


Appendix F. Illustration of a $10 \times 10 \mathrm{~m}$ vegetation plot used to sample vegetation characteristics on the trap and translocation sides of each of the 11 study sites. Two $2 \times 2$ $\mathrm{m}$ plots were used to sample the density of coniferous and deciduous small trees, saplings, and shrubs. The $10 \times 10 \mathrm{~m}$ plot was centered on a tree marked with flagging tape in order to use the point-centered quarter method to measure tree dispersion and fallen log dispersion in each quarter. Other vegetation characteristics sampled per plot included: proportion of non-woody vegetation cover, proportion canopy cover, and percent of a $10 \mathrm{~m}$ transect covered by coarse woody debris.

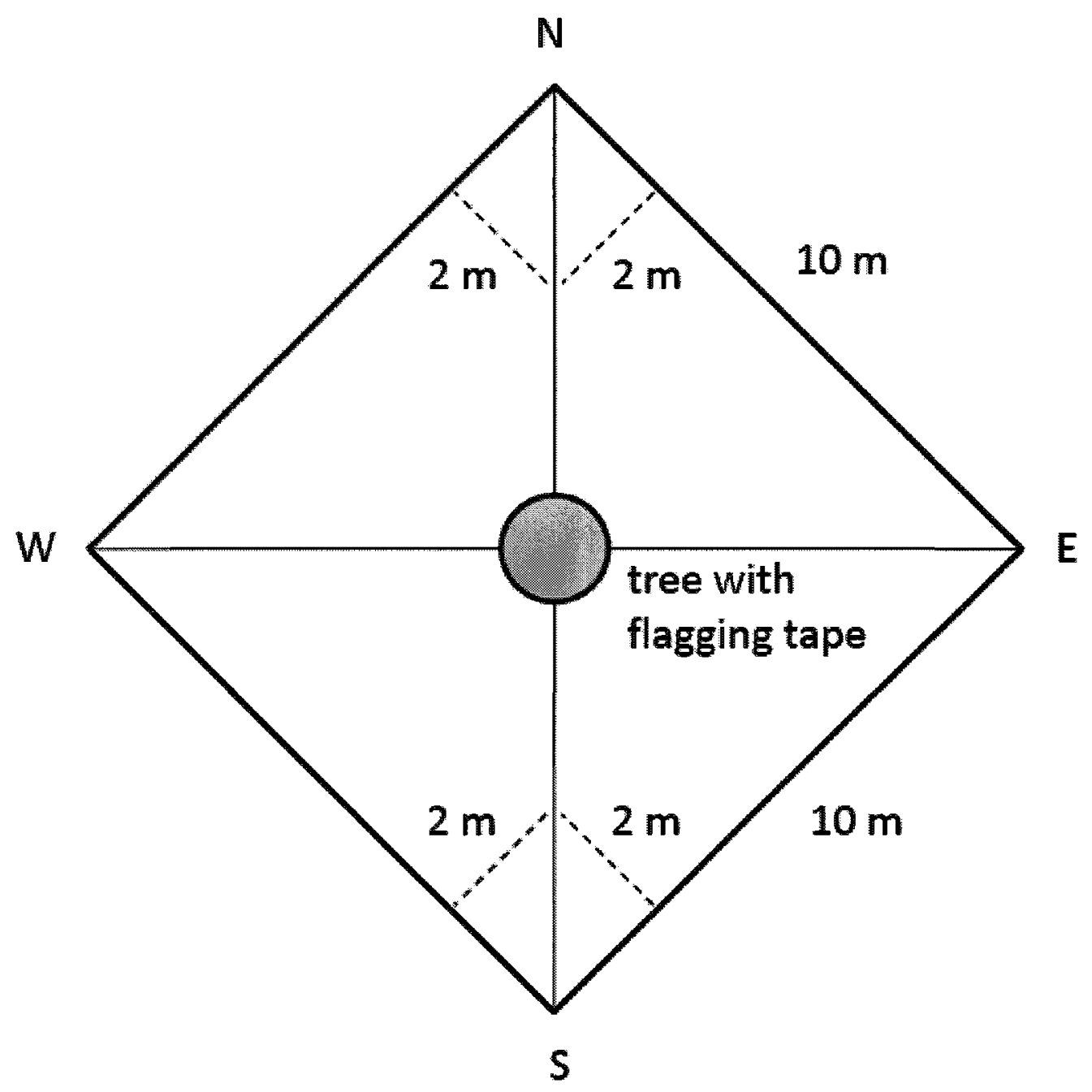


Appendix G. Results of multivariate general linear model analyses on the relationship between the proportion of individuals recaptured after translocation and median cover type, median width, and their interaction for (a) all data combined, (b) males, (c) females, (d) adults, and (e) juveniles. Proportion statistics were calculated for each of the 11 study sites as the number of individuals recaptured out of the total number of individuals translocated during the 7-day trapping session.

\begin{tabular}{lccc}
\hline Parameter & Estimate & F & P \\
\hline (a) All data combined & & & \\
Intercept & 0.203 & 1.319 & 0.289 \\
Median cover (grass) & -0.101 & 0.145 & 0.714 \\
Median width & $8.953^{-6}$ & 0.077 & 0.790 \\
Median cover (grass) $\times$ Median width & 0.002 & 0.076 & 0.791 \\
(b) Males & & & \\
Intercept & 0.336 & 3.787 & 0.093 \\
Median cover (grass) & -0.059 & 0.035 & 0.858 \\
Median width & -0.006 & 0.421 & 0.537 \\
Median cover (grass) $\times$ Median width & 0.006 & 0.419 & 0.538 \\
(c) Females & & & \\
Intercept & 0.543 & 2.728 & 0.413 \\
Median cover (grass) & -0.625 & 5.009 & 0.060 \\
Median width & -0.011 & 0.535 & 0.488 \\
Median cover (grass) $\times$ Median width & 0.015 & 2.866 & 0.134 \\
(d) Adults & & & \\
Intercept & 0.301 & 2.702 & 0.144 \\
Median cover (grass) & -0.061 & 0.035 & 0.857 \\
Median width & -0.002 & 0.062 & 0.811 \\
Median cover (grass) $\times$ Median width & 0.001 & 0.006 & 0.942 \\
(e) Juveniles & & & \\
Intercept & 0.154 & 0.255 & 0.635 \\
Median cover (grass) & -0.154 & 0.255 & 0.635 \\
Median width & -0.003 & 0.076 & 0.794 \\
Median cover (grass) $\times$ Median width & 0.003 & 0.076 & 0.794 \\
\hline & & & \\
\hline
\end{tabular}

Note: parameter estimates for categorical variables are relative to reference levels (lowest level of each variable) 
Appendix H. Proportion of small mammals that were recaptured during 7-day trapping sessions at 11 study sites after translocation across highways containing medians vegetated with grass $(\boldsymbol{O})$ or trees $(\mathrm{x})$. The proportion of individuals recaptured was not significantly related to median cover type $\left(F_{1,7}=0.145, P=0.714\right)$ or median width $\left(\mathrm{F}_{1,7}=0.077, \mathrm{P}=0.790\right)$.

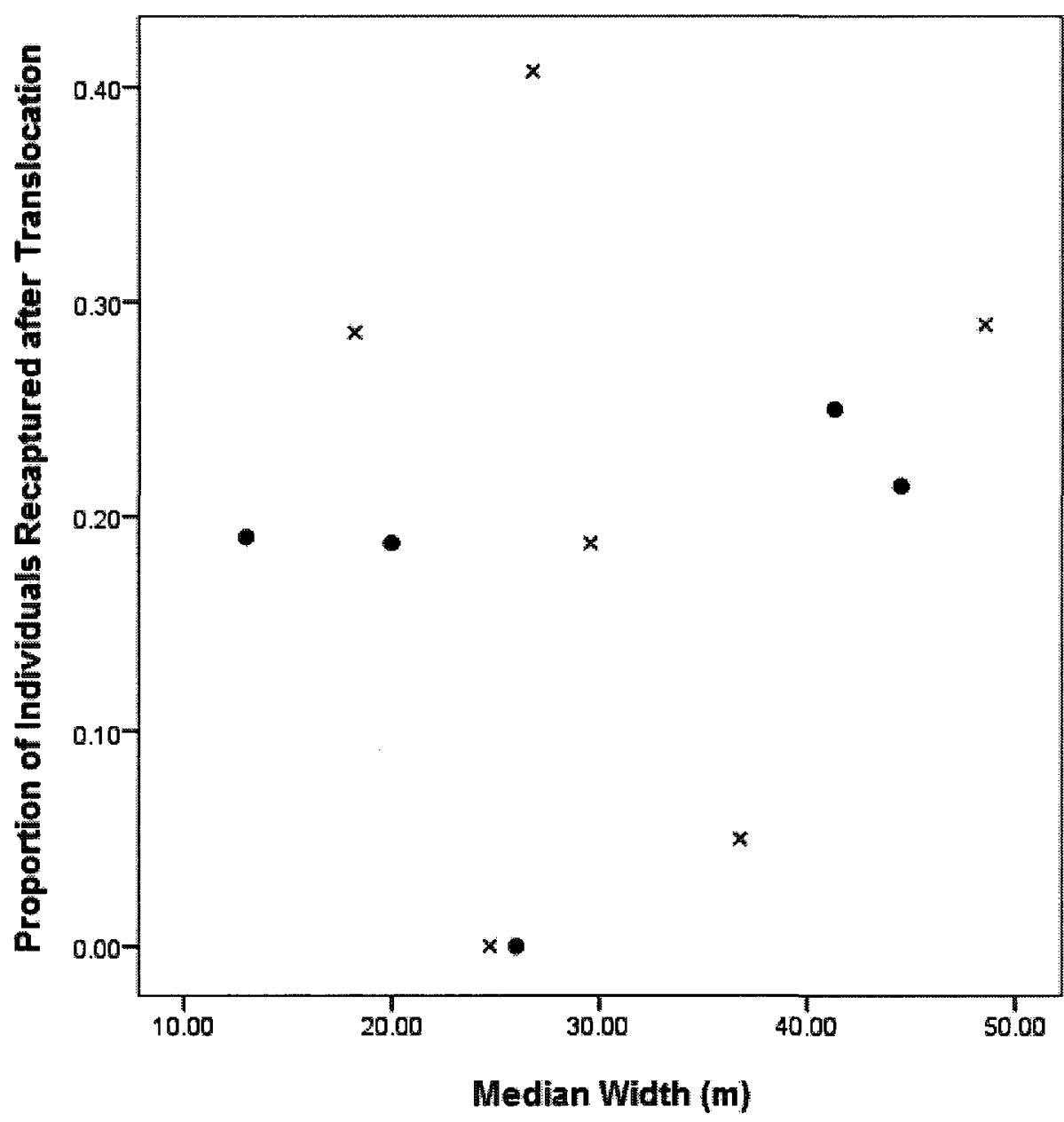

- Grass median

$x$ Treed median 
Appendix I. Boxplots showing the marginally significant effect of median cover type on the proportion of females recaptured after translocation across divided highways during 7-day trapping sessions $\left(\mathrm{F}_{1,7}=5.009, \mathrm{P}=0.060\right)$ : most females were not recaptured when translocated across highways with grass medians, except at one site $\left(^{*}\right)$ where $20 \%$ of translocated females were recaptured. The proportion of males that were recaptured at the 11 study sites was not significantly related to median cover type $\left(\mathrm{F}_{1,7}=0.035, \mathrm{P}=0.858\right)$. [statistics from multivariate general linear model analyses in Appendix G].

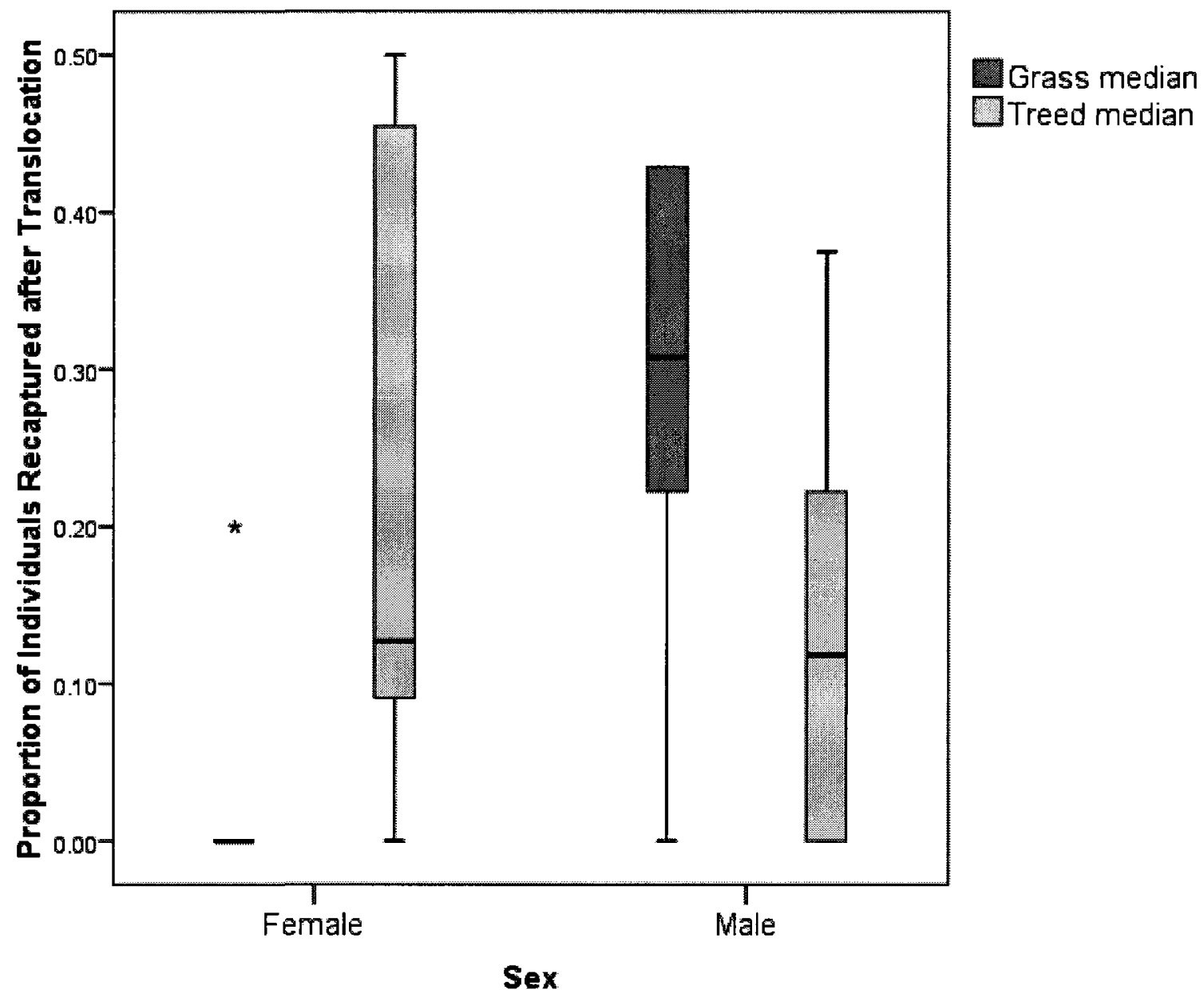


Appendix J. Data collected during 7-day trapping sessions at the 11 highway study sites: start date of trapping session, site name with highway number (i.e. 416 or 417 ), individual recaptured (1) or not $(0)$, median width $(\mathrm{m})$, median cover type, species (PL $=$ Peromyscus leucopus; $\mathrm{PM}=$ Peromyscus maniculatus $; \mathrm{CG}=$ Clethrionomys gapperi $; \mathrm{TS}$ = Tamias striatus; $\mathrm{NI}=$ Napaeozapus insignis; $\mathrm{ZH}=$ Zapus hudsonius), sex and age class of individual, number of days remaining in trapping session from day of release, and number of days between release and recapture of individual.

\begin{tabular}{|c|c|c|c|c|c|c|c|c|c|}
\hline DATE & SITE & RECAP. & $\begin{array}{c}\text { WIDTH } \\
\text { (m) }\end{array}$ & COVER & SPECIES & SEX & $\begin{array}{c}\text { AGE } \\
\text { CLASS }\end{array}$ & $\begin{array}{l}\text { DAYS LEFT } \\
\text { IN SESSION }\end{array}$ & $\begin{array}{c}\text { DAYS TO } \\
\text { RECAPTURE }\end{array}$ \\
\hline \multirow[t]{2}{*}{ 4-May-08 } & $417 \mathrm{D}$ & 1 & 18.2 & trees & PL & $\mathbf{M}$ & Adult & 5 & 1 \\
\hline & & 1 & 18.2 & trees & PL & $\mathbf{F}$ & Adult & 5 & 1 \\
\hline \multirow[t]{2}{*}{ 16-May-08 } & $417 \mathrm{~B}$ & 0 & 26 & grass & $\mathrm{CG}$ & $\mathbf{M}$ & Adult & 1 & $\mathbf{n} / \mathrm{a}$ \\
\hline & & 0 & 26 & grass & PL & $\mathrm{F}$ & Sub-adult & 5 & $\mathrm{n} / \mathrm{a}$ \\
\hline \multirow[t]{3}{*}{ 28-May-08 } & $417 \mathrm{E}$ & 0 & 24.74 & trees & CG & $\mathrm{F}$ & Adult & 5 & $\mathrm{n} / \mathrm{a}$ \\
\hline & & 0 & 24.74 & trees & CG & $\mathbf{M}$ & Adult & 2 & $\mathrm{n} / \mathrm{a}$ \\
\hline & & 0 & 24.74 & trees & TS & $\mathbf{M}$ & Juvenile & 1 & $\mathrm{n} / \mathrm{a}$ \\
\hline \multirow[t]{5}{*}{ 9-Jun-08 } & $417 \mathrm{H}$ & 1 & 48.54 & trees & PL & $\mathbf{M}$ & Adult & 5 & 1 \\
\hline & & 1 & 48.54 & trees & PL & $\mathbf{M}$ & Sub-adult & 1 & 1 \\
\hline & & 0 & 48.54 & trees & $\mathrm{CG}$ & $\mathbf{M}$ & Adult & 4 & $n / a$ \\
\hline & & 0 & 48.54 & trees & $\mathrm{CG}$ & $\mathrm{F}$ & Sub-adult & 3 & $\mathrm{n} / \mathrm{a}$ \\
\hline & & 1 & 48.54 & trees & CG & $\mathbf{M}$ & Sub-adult & 2 & 2 \\
\hline \multirow[t]{16}{*}{ 18-Jun-08 } & $416 \mathrm{C}$ & 1 & 29.6 & trees & CG & $\mathbf{M}$ & Adult & 4 & 2 \\
\hline & & 1 & 29.6 & trees & CG & $\mathrm{F}$ & Sub-adult & 3 & 2 \\
\hline & & 0 & 29.6 & trees & $\mathrm{CG}$ & $F$ & Adult & 5 & $\mathrm{n} / \mathrm{a}$ \\
\hline & & 0 & 29.6 & trees & CG & $\mathbf{F}$ & Adult & 5 & $\mathrm{n} / \mathrm{a}$ \\
\hline & & 0 & 29.6 & trees & CG & $\mathrm{F}$ & Adult & 5 & $\mathrm{n} / \mathrm{a}$ \\
\hline & & 0 & 29.6 & trees & CG & $\mathbf{M}$ & Sub-adult & 4 & $\mathrm{n} / \mathrm{a}$ \\
\hline & & 0 & 29.6 & trees & CG & $\mathbf{M}$ & Adult & 4 & $\mathrm{n} / \mathrm{a}$ \\
\hline & & 0 & 29.6 & trees & $\mathrm{CG}$ & $\mathrm{F}$ & Adult & 2 & $\mathrm{n} / \mathrm{a}$ \\
\hline & & 0 & 29.6 & trees & $\mathrm{CG}$ & $\mathbf{M}$ & Juvenile & 4 & $\mathrm{n} / \mathrm{a}$ \\
\hline & & 0 & 29.6 & trees & CG & $\mathrm{F}$ & Sub-adult & 3 & $\mathrm{n} / \mathrm{a}$ \\
\hline & & 0 & 29.6 & trees & CG & $\mathbf{M}$ & Sub-adult & 3 & $\mathrm{n} / \mathrm{a}$ \\
\hline & & 0 & 29.6 & trees & CG & $\mathbf{M}$ & Sub-adult & 1 & $n / a$ \\
\hline & & 0 & 29.6 & trees & $\mathrm{CG}$ & $\mathrm{F}$ & Adult & 4 & $\mathrm{n} / \mathrm{a}$ \\
\hline & & 0 & 29.6 & trees & CG & $\mathbf{M}$ & Sub-adult & 2 & $\mathrm{n} / \mathrm{a}$ \\
\hline & & 1 & 29.6 & trees & PL & $\mathbf{M}$ & Adult & 5 & 1 \\
\hline & & 0 & 29.6 & trees & PL & $\mathbf{M}$ & Adult & 4 & $\mathbf{n} / \mathbf{a}$ \\
\hline \multirow[t]{8}{*}{ 3-Jul-08 } & $416 \mathrm{~A}$ & 1 & 13 & grass & PL & $\mathbf{M}$ & Adult & 5 & 1 \\
\hline & & 1 & 13 & grass & PL & $\mathbf{M}$ & Adult & 5 & 1 \\
\hline & & 1 & 13 & grass & PL & $\mathbf{M}$ & Sub-adult & 4 & 1 \\
\hline & & 1 & 13 & grass & PL & $\mathbf{M}$ & Sub-adult & 2 & 1 \\
\hline & & 0 & 13 & grass & PL & $\mathrm{F}$ & Sub-adult & 5 & $\mathrm{n} / \mathrm{a}$ \\
\hline & & 0 & 13 & grass & PL & $\mathbf{M}$ & Juvenile & 5 & $\mathbf{n} / \mathbf{a}$ \\
\hline & & 0 & 13 & grass & PL & $\mathbf{M}$ & Juvenile & 2 & $\mathbf{n} / \mathbf{a}$ \\
\hline & & 0 & 13 & grass & PL & $\mathbf{M}$ & Sub-adult & 3 & $\mathrm{n} / \mathrm{a}$ \\
\hline
\end{tabular}




\section{Appendix J. (continued)}

\begin{tabular}{|c|c|c|c|c|c|c|c|c|c|}
\hline DATE & SITE & RECAP. & $\begin{array}{c}\text { WIDTH } \\
(\mathrm{m})\end{array}$ & COVER & SPECIES & SEX & $\begin{array}{c}\text { AGE } \\
\text { CLASS }\end{array}$ & $\begin{array}{l}\text { DAYS LEFT } \\
\text { IN SESSION }\end{array}$ & $\begin{array}{c}\text { DAYS TO } \\
\text { RECAPTURE }\end{array}$ \\
\hline \multirow[t]{13}{*}{ 3-Jul-08 } & $416 \mathrm{~A}$ & 0 & 13 & grass & PL & $\mathbf{M}$ & Juvenile & 3 & $n / a$ \\
\hline & & 0 & 13 & grass & PL & $\mathrm{F}$ & Juvenile & 4 & $n / a$ \\
\hline & & 0 & 13 & grass & PL & $\mathbf{F}$ & Adult & 5 & $n / a$ \\
\hline & & 0 & 13 & grass & PL & M & Adult & 5 & $n / a$ \\
\hline & & 0 & 13 & grass & PL & $\mathbf{M}$ & Juvenile & 4 & $n / a$ \\
\hline & & 0 & 13 & grass & PL & $\mathbf{F}$ & Sub-adult & 1 & $n / a$ \\
\hline & & 0 & 13 & grass & TS & M & Juvenile & 5 & $n / a$ \\
\hline & & 0 & 13 & grass & TS & $\mathbf{F}$ & Juvenile & 5 & $n / a$ \\
\hline & & 0 & 13 & grass & TS & $\mathbf{F}$ & Sub-adult & 5 & $n / a$ \\
\hline & & 0 & 13 & grass & TS & $\mathbf{F}$ & Sub-adult & 4 & $n / a$ \\
\hline & & 0 & 13 & grass & TS & M & Juvenile & 2 & $n / a$ \\
\hline & & 0 & 13 & grass & TS & M & Adult & 2 & $n / a$ \\
\hline & & 0 & 13 & grass & TS & $\mathbf{F}$ & Sub-adult & 1 & $n / a$ \\
\hline \multirow[t]{27}{*}{ 14-Jul-08 } & $417 \mathrm{~F}$ & 1 & 26.8 & trees & PL & M & Sub-adult & 4 & 1 \\
\hline & & 1 & 26.8 & trees & PL & M & Sub-adult & 5 & 1 \\
\hline & & 1 & 26.8 & trees & PL & M & Adult & 5 & 2 \\
\hline & & 1 & 26.8 & trees & PL & M & Adult & 5 & 2 \\
\hline & & 1 & 26.8 & trees & PL & $\mathrm{F}$ & Juvenile & 3 & 1 \\
\hline & & 1 & 26.8 & trees & PL & F & Sub-adult & 5 & 2 \\
\hline & & 1 & 26.8 & trees & PL & $\mathbf{F}$ & Juvenile & 4 & 1 \\
\hline & & 0 & 26.8 & trees & PL & $\mathbf{F}$ & Juvenile & 4 & $n / a$ \\
\hline & & 0 & 26.8 & trees & PL & M & Adult & 3 & $n / a$ \\
\hline & & 0 & 26.8 & trees & PL & M & Adult & 2 & $n / a$ \\
\hline & & 1 & 26.8 & trees & PM & M & Adult & 4 & 1 \\
\hline & & 1 & 26.8 & trees & PM & $F$ & Sub-adult & 5 & 3 \\
\hline & & 1 & 26.8 & trees & PM & $\mathbf{F}$ & Adult & 5 & 3 \\
\hline & & 1 & 26.8 & trees & PM & M & Adult & 4 & 4 \\
\hline & & 0 & 26.8 & trees & PM & M & Adult & 4 & $n / a$ \\
\hline & & 0 & 26.8 & trees & PM & $F$ & Juvenile & 3 & $\mathrm{n} / \mathrm{a}$ \\
\hline & & 0 & 26.8 & trees & CG & M & Adult & 5 & $n / a$ \\
\hline & & 0 & 26.8 & trees & CG & F & Adult & 5 & $n / a$ \\
\hline & & 0 & 26.8 & trees & CG & M & Adult & 5 & $n / a$ \\
\hline & & 0 & 26.8 & trees & CG & M & Adult & 4 & $n / a$ \\
\hline & & 0 & 26.8 & trees & CG & $\mathrm{F}$ & Juvenile & 4 & $\mathrm{n} / \mathrm{a}$ \\
\hline & & 0 & 26.8 & trees & CG & M & Adult & 3 & $n / a$ \\
\hline & & 0 & 26.8 & trees & CG & M & Adult & 3 & $\mathrm{n} / \mathrm{a}$ \\
\hline & & 0 & 26.8 & trees & CG & M & Adult & 3 & $\mathrm{n} / \mathrm{a}$ \\
\hline & & 0 & 26.8 & trees & CG & F & Adult & 2 & $n / a$ \\
\hline & & 0 & 26.8 & trees & CG & F & Adult & 1 & $\mathrm{n} / \mathrm{a}$ \\
\hline & & 0 & 26.8 & trees & CG & M & Sub-adult & 1 & $\mathrm{n} / \mathrm{a}$ \\
\hline \multirow[t]{5}{*}{ 23-Jul-08 } & $416 \mathrm{~B}$ & 1 & 44.5 & grass & PL & M & Adult & 3 & 1 \\
\hline & & 1 & 44.5 & grass & PL & $\mathbf{F}$ & Adult & 2 & 1 \\
\hline & & 0 & 44.5 & grass & PL & F & Sub-adult & 4 & $\mathrm{n} / \mathrm{a}$ \\
\hline & & 0 & 44.5 & grass & PL & M & Adult & 4 & $n / a$ \\
\hline & & 0 & 44.5 & grass & PL & M & Adult & 2 & $n / a$ \\
\hline
\end{tabular}


Appendix J. (continued)

\begin{tabular}{|c|c|c|c|c|c|c|c|c|c|}
\hline DATE & SITE & RECAP. & $\begin{array}{c}\text { WIDTH } \\
\text { (m) }\end{array}$ & COVER & SPECIES & SEX & $\begin{array}{c}\text { AGE } \\
\text { CLASS }\end{array}$ & $\begin{array}{l}\text { DAYS LEFT } \\
\text { IN SESSION }\end{array}$ & $\begin{array}{c}\text { DAYS TO } \\
\text { RECAPTURE }\end{array}$ \\
\hline \multirow[t]{9}{*}{ 23-Jul-08 } & $416 \mathrm{~B}$ & 0 & 44.5 & grass & PL & $\mathbf{M}$ & Adult & 1 & $\mathbf{n} / \mathbf{a}$ \\
\hline & & 0 & 44.5 & grass & NI & $\mathrm{F}$ & Adult & 3 & $\mathrm{n} / \mathrm{a}$ \\
\hline & & 0 & 44.5 & grass & NI & $\mathrm{F}$ & Adult & 1 & $\mathrm{n} / \mathrm{a}$ \\
\hline & & 0 & 44.5 & grass & TS & $\mathbf{M}$ & Adult & 2 & $\mathrm{n} / \mathrm{a}$ \\
\hline & & 1 & 44.5 & grass & CG & $\mathbf{M}$ & Adult & 5 & 3 \\
\hline & & 0 & 44.5 & grass & CG & $\mathbf{M}$ & Adult & 5 & $n / a$ \\
\hline & & 0 & 44.5 & grass & $\mathrm{CG}$ & $\mathrm{F}$ & Sub-adult & 5 & $n / a$ \\
\hline & & 0 & 44.5 & grass & CG & $\mathbf{M}$ & Adult & 4 & $\mathrm{n} / \mathrm{a}$ \\
\hline & & 0 & 44.5 & grass & $\mathrm{CG}$ & $\mathbf{M}$ & Adult & 3 & $\mathrm{n} / \mathrm{a}$ \\
\hline \multirow[t]{12}{*}{ 1-Aug-08 } & $417 \mathrm{C}$ & 1 & 41.32 & grass & PL & $\mathbf{M}$ & Sub-adult & 5 & 1 \\
\hline & & 0 & 41.32 & grass & PL & $\mathbf{M}$ & Adult & 1 & $\mathrm{n} / \mathrm{a}$ \\
\hline & & 0 & 41.32 & grass & NI & $\mathrm{F}$ & Juvenile & 4 & $n / a$ \\
\hline & & 0 & 41.32 & grass & NI & $\mathrm{F}$ & Adult & 1 & $\mathrm{n} / \mathrm{a}$ \\
\hline & & 0 & 41.32 & grass & NI & $\mathrm{F}$ & Adult & 1 & $\mathrm{n} / \mathrm{a}$ \\
\hline & & 0 & 41.32 & grass & NI & $\mathrm{F}$ & Adult & 1 & $\mathrm{n} / \mathrm{a}$ \\
\hline & & 0 & 41.32 & grass & NI & $\mathbf{M}$ & Adult & 1 & $\mathrm{n} / \mathrm{a}$ \\
\hline & & 1 & 41.32 & grass & $\mathrm{CG}$ & $\mathbf{M}$ & Adult & 5 & 1 \\
\hline & & 1 & 41.32 & grass & CG & $\mathbf{M}$ & Adult & 3 & 1 \\
\hline & & 0 & 41.32 & grass & CG & $\mathrm{F}$ & Sub-adult & 3 & $\mathrm{n} / \mathrm{a}$ \\
\hline & & 0 & 41.32 & grass & CG & $\mathbf{M}$ & Adult & 3 & $\mathrm{n} / \mathrm{a}$ \\
\hline & & 0 & 41.32 & grass & $\mathrm{CG}$ & $\mathbf{M}$ & Adult & 2 & $\mathrm{n} / \mathrm{a}$ \\
\hline \multirow[t]{16}{*}{ 10-Aug-08 } & $417 \mathrm{~A}$ & 1 & 20 & grass & PL & $\mathbf{M}$ & Adult & 5 & 1 \\
\hline & & 1 & 20 & grass & PL & $\mathbf{M}$ & Adult & 5 & 1 \\
\hline & & 1 & 20 & grass & PL & $\mathbf{M}$ & Adult & 1 & 1 \\
\hline & & 0 & 20 & grass & PL & $\mathrm{F}$ & Juvenile & 4 & $\mathrm{n} / \mathrm{a}$ \\
\hline & & 0 & 20 & grass & PL & $\mathbf{M}$ & Sub-adult & 2 & $\mathrm{n} / \mathrm{a}$ \\
\hline & & 0 & 20 & grass & PL & $\mathrm{F}$ & Juvenile & 2 & $\mathrm{n} / \mathrm{a}$ \\
\hline & & 0 & 20 & grass & PL & $\mathrm{F}$ & Juvenile & 1 & $\mathrm{n} / \mathrm{a}$ \\
\hline & & 0 & 20 & grass & PL & $\mathrm{F}$ & Juvenile & 1 & $\mathrm{n} / \mathrm{a}$ \\
\hline & & 0 & 20 & grass & CG & $\mathrm{F}$ & Adult & 5 & $\mathrm{n} / \mathrm{a}$ \\
\hline & & 0 & 20 & grass & CG & $\mathbf{M}$ & Adult & 5 & $\mathrm{n} / \mathrm{a}$ \\
\hline & & 0 & 20 & grass & $\mathrm{CG}$ & $\mathrm{F}$ & Sub-adult & 4 & $\mathrm{n} / \mathrm{a}$ \\
\hline & & 0 & 20 & grass & $\mathrm{CG}$ & $\mathbf{M}$ & Adult & 3 & $\mathrm{n} / \mathrm{a}$ \\
\hline & & 0 & 20 & grass & $\mathrm{CG}$ & $\mathrm{F}$ & Sub-adult & 3 & $\mathrm{n} / \mathrm{a}$ \\
\hline & & 0 & 20 & grass & CG & F & Adult & 2 & $\mathrm{n} / \mathrm{a}$ \\
\hline & & 0 & 20 & grass & CG & F & Adult & 2 & $n / a$ \\
\hline & & 0 & 20 & grass & $\mathrm{CG}$ & $\mathbf{M}$ & Juvenile & 1 & $\mathrm{n} / \mathrm{a}$ \\
\hline \multirow[t]{8}{*}{ 19-Aug-08 } & $417 \mathrm{G}$ & 1 & 36.8 & trees & PL & $\mathrm{F}$ & Adult & 5 & 2 \\
\hline & & 0 & 36.8 & trees & PL & $\mathbf{M}$ & Adult & 3 & $\mathrm{n} / \mathrm{a}$ \\
\hline & & 0 & 36.8 & trees & PL & $\mathbf{M}$ & Sub-adult & 2 & $\mathrm{n} / \mathrm{a}$ \\
\hline & & 0 & 36.8 & trees & PL & $\mathbf{M}$ & Juvenile & 2 & $\mathrm{n} / \mathrm{a}$ \\
\hline & & 0 & 36.8 & trees & $\mathrm{NI}$ & $\mathbf{M}$ & Adult & 2 & $\mathrm{n} / \mathrm{a}$ \\
\hline & & 0 & 36.8 & trees & $\mathrm{CG}$ & $\mathbf{M}$ & Juvenile & 5 & $\mathrm{n} / \mathrm{a}$ \\
\hline & & 0 & 36.8 & trees & $\mathrm{CG}$ & $\mathrm{F}$ & Sub-adult & 5 & $\mathrm{n} / \mathrm{a}$ \\
\hline & & 0 & 36.8 & trees & $\mathrm{CG}$ & $F$ & Adult & 4 & $\mathrm{n} / \mathrm{a}$ \\
\hline
\end{tabular}


Appendix J. (continued)

\begin{tabular}{|c|c|c|c|c|c|c|c|c|c|}
\hline DATE & SITE & RECAP. & $\begin{array}{l}\text { WIDTH } \\
\text { (m) }\end{array}$ & COVER & SPECIES & SEX & $\begin{array}{c}\text { AGE } \\
\text { CLASS }\end{array}$ & $\begin{array}{l}\text { DAYS LEFT } \\
\text { IN SESSION }\end{array}$ & $\begin{array}{c}\text { DAYS TO } \\
\text { RECAPTURE }\end{array}$ \\
\hline \multirow{12}{*}{ 19-Aug-08 } & $417 \mathrm{G}$ & 0 & 36.8 & trees & $\mathrm{CG}$ & $\mathbf{F}$ & Adult & 4 & $\mathbf{n} / \mathbf{a}$ \\
\hline & & 0 & 36.8 & trees & $\mathrm{CG}$ & $\mathbf{M}$ & Adult & 4 & $\mathrm{n} / \mathrm{a}$ \\
\hline & & 0 & 36.8 & trees & $\mathrm{CG}$ & $F$ & Adult & 4 & $\mathrm{n} / \mathrm{a}$ \\
\hline & & 0 & 36.8 & trees & CG & $\mathbf{M}$ & Juvenile & 4 & $\mathrm{n} / \mathrm{a}$ \\
\hline & & 0 & 36.8 & trees & CG & $\mathrm{F}$ & Adult & 3 & $\mathrm{n} / \mathrm{a}$ \\
\hline & & 0 & 36.8 & trees & $\mathrm{CG}$ & $\mathrm{F}$ & Adult & 2 & $\mathrm{n} / \mathrm{a}$ \\
\hline & & 0 & 36.8 & trees & $\mathrm{CG}$ & $\mathbf{M}$ & Adult & 2 & $\mathrm{n} / \mathrm{a}$ \\
\hline & & 0 & 36.8 & trees & $\mathrm{CG}$ & $\mathbf{M}$ & Juvenile & 2 & $n / a$ \\
\hline & & 0 & 36.8 & trees & $\mathrm{CG}$ & $\mathrm{F}$ & Adult & 2 & $\mathrm{n} / \mathrm{a}$ \\
\hline & & 0 & 36.8 & trees & $\mathrm{CG}$ & $\mathrm{F}$ & Juvenile & 2 & $\mathrm{n} / \mathrm{a}$ \\
\hline & & 0 & 36.8 & trees & $\mathrm{CG}$ & $\mathbf{M}$ & Juvenile & 2 & $\mathbf{n} / \mathbf{a}$ \\
\hline & & 0 & 36.8 & trees & $\mathrm{CG}$ & $\mathbf{M}$ & Adult & 1 & $\mathrm{n} / \mathrm{a}$ \\
\hline \multirow[t]{19}{*}{ 28-Aug-08 } & $417 \mathrm{D}$ & 1 & 18.2 & trees & PL & $\mathrm{F}$ & Adult & 5 & 2 \\
\hline & & 1 & 18.2 & trees & PL & $M$ & Adult & 4 & 1 \\
\hline & & 0 & 18.2 & trees & PL & $M$ & Juvenile & 4 & $\mathrm{n} / \mathrm{a}$ \\
\hline & & 0 & 18.2 & trees & PL & $F$ & Adult & 4 & $\mathrm{n} / \mathrm{a}$ \\
\hline & & 0 & 18.2 & trees & PL & $\mathbf{M}$ & Juvenile & 3 & $\mathrm{n} / \mathrm{a}$ \\
\hline & & 0 & 18.2 & trees & PL & $\mathbf{M}$ & Juvenile & 3 & $n / a$ \\
\hline & & 0 & 18.2 & trees & PL & $M$ & Juvenile & 2 & $\mathrm{n} / \mathrm{a}$ \\
\hline & & 0 & 18.2 & trees & PL & $\mathbf{M}$ & Adult & 2 & $\mathrm{n} / \mathrm{a}$ \\
\hline & & 0 & 18.2 & trees & PL & $\mathbf{M}$ & Juvenile & 2 & $\mathrm{n} / \mathbf{a}$ \\
\hline & & 0 & 18.2 & trees & PL & $\mathrm{F}$ & Juvenile & 2 & $n / a$ \\
\hline & & 0 & 18.2 & trees & PL & $\mathbf{M}$ & Juvenile & 1 & $\mathrm{n} / \mathrm{a}$ \\
\hline & & 0 & 18.2 & trees & PL & $\mathbf{M}$ & Juvenile & 1 & $\mathrm{n} / \mathrm{a}$ \\
\hline & & 1 & 18.2 & trees & TS & $\mathbf{F}$ & Sub-adult & 3 & 1 \\
\hline & & 0 & 18.2 & trees & TS & $\mathbf{M}$ & Sub-adult & 4 & $\mathrm{n} / \mathrm{a}$ \\
\hline & & 0 & 18.2 & trees & TS & $\mathbf{M}$ & Sub-adult & 3 & $\mathrm{n} / \mathrm{a}$ \\
\hline & & 0 & 18.2 & trees & TS & $\mathrm{F}$ & Adult & 1 & $\mathrm{n} / \mathrm{a}$ \\
\hline & & 1 & 18.2 & trees & $\mathrm{CG}$ & $\mathbf{M}$ & Adult & 5 & 3 \\
\hline & & 0 & 18.2 & trees & $\mathrm{CG}$ & $\mathbf{M}$ & Sub-adult & 4 & $\mathrm{n} / \mathrm{a}$ \\
\hline & & 0 & 18.2 & trees & $\mathrm{CG}$ & $\mathbf{M}$ & Adult & 1 & $\mathrm{n} / \mathrm{a}$ \\
\hline \multirow[t]{14}{*}{ 6-Sep-08 } & $417 \mathrm{H}$ & 1 & 48.54 & trees & PL & $\mathbf{M}$ & Adult & 5 & 1 \\
\hline & & 1 & 48.54 & trees & PL & $\mathbf{M}$ & Adult & 5 & 2 \\
\hline & & 0 & 48.54 & trees & PL & $\mathbf{M}$ & Adult & 5 & $\mathrm{n} / \mathrm{a}$ \\
\hline & & 0 & 48.54 & trees & PL & $\mathbf{M}$ & Adult & 4 & $\mathrm{n} / \mathrm{a}$ \\
\hline & & 0 & 48.54 & trees & PL & $\mathbf{M}$ & Juvenile & 3 & $\mathrm{n} / \mathbf{a}$ \\
\hline & & 0 & 48.54 & trees & PL & $\mathrm{F}$ & Juvenile & 2 & $\mathrm{n} / \mathbf{a}$ \\
\hline & & 0 & 48.54 & trees & PL & $\mathbf{M}$ & Juvenile & 1 & $\mathbf{n} / \mathbf{a}$ \\
\hline & & 0 & 48.54 & trees & PL & $\mathbf{M}$ & Adult & 1 & $\mathrm{n} / \mathrm{a}$ \\
\hline & & 1 & 48.54 & trees & NI & $\mathrm{F}$ & Adult & 5 & 2 \\
\hline & & 1 & 48.54 & trees & NI & $\mathbf{M}$ & Adult & 4 & 1 \\
\hline & & 1 & 48.54 & trees & NI & $\mathbf{M}$ & Adult & 4 & 2 \\
\hline & & 1 & 48.54 & trees & NI & $\mathbf{M}$ & Adult & 4 & 3 \\
\hline & & 1 & 48.54 & trees & NI & M & Adult & 2 & 2 \\
\hline & & 0 & 48.54 & trees & NI & $\mathrm{F}$ & Sub-adult & 5 & $\mathrm{n} / \mathrm{a}$ \\
\hline
\end{tabular}




\section{Appendix J. (continued)}

\begin{tabular}{|c|c|c|c|c|c|c|c|c|c|}
\hline DATE & SITE & RECAP. & $\begin{array}{c}\text { WIDTH } \\
(\mathrm{m})\end{array}$ & COVER & SPECIES & SEX & $\begin{array}{c}\text { AGE } \\
\text { CLASS }\end{array}$ & $\begin{array}{l}\text { DAYS LEFT } \\
\text { IN SESSION }\end{array}$ & $\begin{array}{c}\text { DAYS TO } \\
\text { RECAPTURE }\end{array}$ \\
\hline \multirow[t]{19}{*}{ 6-Sep-08 } & $417 \mathrm{H}$ & 0 & 48.54 & trees & $\mathrm{NI}$ & $\mathbf{M}$ & Adult & 5 & $\mathrm{n} / \mathrm{a}$ \\
\hline & & 0 & 48.54 & trees & $\mathrm{NI}$ & $\mathrm{F}$ & Adult & 4 & $\mathrm{n} / \mathrm{a}$ \\
\hline & & 0 & 48.54 & trees & NI & $\mathbf{M}$ & Juvenile & 4 & $\mathrm{n} / \mathrm{a}$ \\
\hline & & 0 & 48.54 & trees & $\mathrm{NI}$ & $\mathrm{F}$ & Adult & 4 & $\mathrm{n} / \mathrm{a}$ \\
\hline & & 0 & 48.54 & trees & NI & $\mathbf{M}$ & Adult & 4 & $\mathbf{n} / \mathbf{a}$ \\
\hline & & 0 & 48.54 & trees & $\mathrm{NI}$ & $\mathrm{F}$ & Adult & 4 & $\mathrm{n} / \mathrm{a}$ \\
\hline & & 0 & 48.54 & trees & $\mathrm{NI}$ & $\mathrm{F}$ & Sub-adult & 3 & $\mathrm{n} / \mathrm{a}$ \\
\hline & & 0 & 48.54 & trees & $\mathrm{NI}$ & $\mathbf{M}$ & Adult & 3 & $\mathrm{n} / \mathrm{a}$ \\
\hline & & 0 & 48.54 & trees & $\mathrm{NI}$ & $\mathbf{M}$ & Adult & 2 & $\mathrm{n} / \mathrm{a}$ \\
\hline & & 0 & 48.54 & trees & NI & $\mathbf{M}$ & Adult & 2 & $\mathrm{n} / \mathrm{a}$ \\
\hline & & 0 & 48.54 & trees & $\mathrm{NI}$ & $\mathbf{M}$ & Adult & 2 & $\mathrm{n} / \mathrm{a}$ \\
\hline & & 0 & 48.54 & trees & $\mathrm{NI}$ & $\mathrm{F}$ & Adult & 1 & $\mathrm{n} / \mathrm{a}$ \\
\hline & & 0 & 48.54 & trees & $\mathrm{NI}$ & $\mathbf{M}$ & Adult & 1 & $\mathrm{n} / \mathrm{a}$ \\
\hline & & 0 & 48.54 & trees & $\mathrm{ZH}$ & $\mathrm{F}$ & Juvenile & 3 & $\mathrm{n} / \mathrm{a}$ \\
\hline & & 0 & 48.54 & trees & $\mathrm{ZH}$ & $\mathbf{M}$ & Sub-adult & 2 & $\mathrm{n} / \mathrm{a}$ \\
\hline & & 1 & 48.54 & trees & $\mathrm{CG}$ & $\mathbf{M}$ & Adult & 5 & 2 \\
\hline & & 0 & 48.54 & trees & $\mathrm{CG}$ & $\mathbf{M}$ & Adult & 3 & $\mathrm{n} / \mathrm{a}$ \\
\hline & & 0 & 48.54 & trees & $\mathrm{CG}$ & F & Juvenile & 1 & $\mathrm{n} / \mathbf{a}$ \\
\hline & & 0 & 48.54 & trees & $\mathrm{CG}$ & $\mathbf{M}$ & Juvenile & 1 & n/a \\
\hline
\end{tabular}


Appendix K. Data from vegetation surveys using point-centered quarter method in $10 \times 10 \mathrm{~m}$ plots at the trap and translocation sides of the highway for each study site. For each quarter of the plots, tree dispersion was measured as the distance between the centre of the plot and the closest tree with a diameter at breast height $(\mathrm{DBH})>10.0 \mathrm{~cm}$. The distance between the centre of the plot and nearest fallen tree log in each quarter was used as a measurement of fallen log dispersion.

\begin{tabular}{|c|c|c|c|c|c|c|c|}
\hline Site & $\begin{array}{c}\text { Side of } \\
\text { Highway }\end{array}$ & $\begin{array}{c}\text { Sampling } \\
\text { Plot }\end{array}$ & 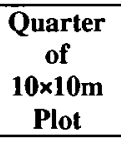 & Tree Species & $\begin{array}{c}\text { DBH } \\
(\mathrm{cm})\end{array}$ & $\begin{array}{c}\text { Tree } \\
\text { Dispersion } \\
\text { (cm) }\end{array}$ & $\begin{array}{c}\text { Fallen } \\
\text { Log } \\
\text { Dispersion } \\
\text { (cm) } \\
\end{array}$ \\
\hline \multirow[t]{16}{*}{$417 \mathrm{D}$} & Trap & A5 & 1 & Red Maple (Acer rubrum) & 13.3 & 111 & 5 \\
\hline & & & 2 & Trembling Aspen (Populus tremuloides) & 33.5 & 337 & 18 \\
\hline & & & 3 & none & $\mathrm{n} / \mathrm{a}$ & $\mathrm{n} / \mathrm{a}$ & 71 \\
\hline & & & 4 & Red Maple (Acer rubrum) & 12 & 381 & 31 \\
\hline & & D8 & 1 & Red Maple (Acer rubrum) & 19.6 & 217 & 71 \\
\hline & & & 2 & Trembling Aspen (Populus tremuloides) & 31.8 & 122 & 53 \\
\hline & & & 3 & Red Maple (Acer rubrum) & 11.9 & 384 & 38 \\
\hline & & & 4 & Balsam Fir (Abies balsamea) & 16.3 & 362 & 44 \\
\hline & & D1 & 1 & Red Maple (Acer rubrum) & 20.8 & 136 & 19 \\
\hline & & & 2 & Red Maple (Acer rubrum) & 10.2 & 306 & 10 \\
\hline & & & 3 & White Ash (Fraxinus americana) & 12.9 & 291 & 58 \\
\hline & & & 4 & White Ash (Fraxinus americana) & 10.1 & 143 & 65 \\
\hline & & G5 & 1 & Trembling Aspen (Populus tremuloides) & 27.3 & 221 & 52 \\
\hline & & & 2 & White Ash (Fraxinus americana) & 16.5 & 342 & 16 \\
\hline & & & 3 & Trembling Aspen (Populus tremuloides) & 32.9 & 264 & 32 \\
\hline & & & 4 & Trembling Aspen (Populus tremuloides) & 32.1 & 503 & 37 \\
\hline \multirow[t]{16}{*}{$417 \mathrm{D}$} & Trans. & A5 & 1 & American Basswood (Tilia americana) & 14.8 & 211 & 37 \\
\hline & & & 2 & Black Ash (Fraxinus nigra) & 12.7 & 421 & 21 \\
\hline & & & 3 & American Basswood (Tilia americana) & 13.3 & 196 & 108 \\
\hline & & & 4 & American Basswood (Tilia americana) & 22.1 & 521 & 33 \\
\hline & & D8 & 1 & Eastern White Cedar (Thuja occidentalis) & 26.9 & 137 & 62 \\
\hline & & & 2 & Eastem White Cedar (Thuja occidentalis) & 21.2 & 398 & 59 \\
\hline & & & 3 & Red Maple (Acer rubrum) & 22.2 & 264 & 47 \\
\hline & & & 4 & American Basswood (Tilia americana) & 14.6 & 491 & 38 \\
\hline & & D1 & 1 & Black Ash (Fraxinus nigra) & 18.2 & 226 & 5 \\
\hline & & & 2 & Black Ash (Fraxinus nigra) & 24.5 & 122 & 3 \\
\hline & & & 3 & American Basswood (Tilia americana) & 15.4 & 182 & 9 \\
\hline & & & 4 & White Ash (Fraxinus americana) & 20.6 & 436 & 11 \\
\hline & & G5 & 1 & Eastern White Cedar (Thuja occidentalis) & 13.8 & 326 & 30 \\
\hline & & & 2 & Black Ash (Fraxinus nigra) & 24 & 291 & 28 \\
\hline & & & 3 & White Ash (Fraxinus americana) & 12.3 & 283 & 63 \\
\hline & & & 4 & American Basswood (Tilia americana) & 14.5 & 385 & 29 \\
\hline \multirow[t]{9}{*}{$417 \mathrm{G}$} & Trap & A5 & 1 & Red Maple (Acer rubrum) & 29.4 & 360 & 9 \\
\hline & & & 2 & Red Maple (Acer rubrum) & 14.9 & 634 & 16 \\
\hline & & & 3 & Quivering Aspen = Trembling Aspen? & 12.4 & 493 & 32 \\
\hline & & & 4 & Red Maple (Acer rubrum) & 20.8 & 298 & 45 \\
\hline & & D8 & 1 & Paper Birch (Betula papyrifera) & 14.7 & 482 & 38 \\
\hline & & & 2 & Red Maple (Acer rubrum) & 30.3 & 635 & 14 \\
\hline & & & 3 & Red Maple (Acer rubrum) & 10.7 & 679 & 29 \\
\hline & & & 4 & Red Maple (Acer rubrum) & 10.1 & 85 & 52 \\
\hline & & D1 & 1 & Red Maple (Acer rubrum) & 16.5 & 377 & 57 \\
\hline
\end{tabular}


Appendix K. (continued)

\begin{tabular}{|c|c|c|c|c|c|c|c|}
\hline Site & $\begin{array}{l}\text { Side of } \\
\text { Highway }\end{array}$ & $\begin{array}{c}\text { Sampling } \\
\text { Plot }\end{array}$ & 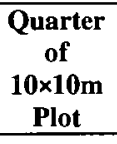 & Tree Species & $\begin{array}{c}\text { DBH } \\
(\mathbf{c m})\end{array}$ & $\begin{array}{c}\text { Tree } \\
\text { Dispersion } \\
\text { (cm) }\end{array}$ & $\begin{array}{c}\begin{array}{c}\text { Fallen } \\
\text { Log } \\
\text { Dispersion } \\
(\mathrm{cm})\end{array} \\
\end{array}$ \\
\hline \multirow[t]{7}{*}{$417 \mathrm{G}$} & Trap & D1 & 2 & Red Maple (Acer rubrum) & 15.6 & 592 & 39 \\
\hline & & & 3 & Red Maple (Acer rubrum) & 11.6 & 483 & 5 \\
\hline & & & 4 & Red Maple (Acer rubrum) & 10.1 & 132 & 51 \\
\hline & & G5 & 1 & Red Maple (Acer rubrum) & 14.4 & 337 & 13 \\
\hline & & & 2 & Paper Birch (Betula papyrifera) & 10.2 & 370 & 5 \\
\hline & & & 3 & none & $\mathrm{n} / \mathrm{a}$ & $\mathrm{n} / \mathrm{a}$ & 3 \\
\hline & & & 4 & none & $\mathrm{n} / \mathrm{a}$ & $\mathrm{n} / \mathbf{a}$ & 6 \\
\hline \multirow[t]{16}{*}{$417 \mathrm{G}$} & Trans. & A5 & 1 & Pin Cherry (Prunus pensylvanica) & 10.1 & 135 & 8 \\
\hline & & & 2 & Red Maple (Acer rubrum) & 10.1 & 252 & 12 \\
\hline & & & 3 & Red Maple (Acer rubrum) & 13.4 & 461 & 4 \\
\hline & & & 4 & $\begin{array}{l}\text { Red Maple (Acer rubrum) } \\
\text { Large-toothed Aspen (Populus }\end{array}$ & 21 & 253 & 17 \\
\hline & & D8 & 1 & grandidentata) & 10.1 & 372 & 20 \\
\hline & & & 2 & Red Maple (Acer rubrum) & 38.9 & 589 & 26 \\
\hline & & & 3 & Black Ash (Fraxinus nigra) & 11.5 & 546 & 51 \\
\hline & & & 4 & Red Maple (Acer rubrum) & 18.4 & 240 & 44 \\
\hline & & D1 & 1 & Red Maple (Acer rubrum) & 24.7 & 124 & 4 \\
\hline & & & 2 & Red Maple (Acer rubrum) & 12.3 & 263 & 2 \\
\hline & & & 3 & Red Maple (Acer rubrum) & 22.6 & 376 & 96 \\
\hline & & & 4 & none & $\mathrm{n} / \mathbf{a}$ & $\mathrm{n} / \mathrm{a}$ & 103 \\
\hline & & G5 & 1 & Paper Birch (Betula papyrifera) & 22.2 & 267 & 8 \\
\hline & & & 2 & Sugar Maple (Acer saccharum) & 14.4 & 465 & 12 \\
\hline & & & 3 & Paper Birch (Betula papyrifera) & 12.5 & 722 & 52 \\
\hline & & & 4 & Paper Birch (Betula papyrifera) & 15.2 & 323 & 64 \\
\hline \multirow[t]{16}{*}{$417 \mathrm{~B}$} & Trap & A5 & 1 & Red Pine (Pinus resinosa) & 22.2 & 157 & 42 \\
\hline & & & 2 & Red Pine (Pinus resinosa) & 12.5 & 356 & 14 \\
\hline & & & 3 & Red Pine (Pinus resinosa) & 13.4 & 209 & 18 \\
\hline & & & 4 & Red Pine (Pinus resinosa) & 27 & 579 & 33 \\
\hline & & D8 & 1 & Red Pine (Pinus resinosa) & 25.6 & 380 & 28 \\
\hline & & & 2 & Pin Cherry (Prunus pensylvanica) & 10.1 & 546 & 45 \\
\hline & & & 3 & Red Pine (Pinus resinosa) & 22.3 & 247 & 53 \\
\hline & & & 4 & Red Pine (Pinus resinosa) & 14.5 & 483 & 34 \\
\hline & & D1 & 1 & Red Pine (Pinus resinosa) & 31.5 & 456 & 53 \\
\hline & & & 2 & Red Pine (Pinus resinosa) & 32.7 & 620 & 40 \\
\hline & & & 3 & Jack Pine (Pinus banksiana) & 23.3 & 78 & 101 \\
\hline & & & 4 & Jack Pine (Pinus banksiana) & 27.5 & 351 & 169 \\
\hline & & G5 & 1 & Trembling Aspen (Populus tremuloides) & 24.8 & 223 & 61 \\
\hline & & & 2 & Trembling Aspen (Populus tremuloides) & 18.8 & 358 & 12 \\
\hline & & & 3 & Red Pine (Pinus resinosa) & 15.4 & 318 & 46 \\
\hline & & & 4 & Shagbark Hickory (Carya ovata) & 23 & 439 & 17 \\
\hline \multirow[t]{6}{*}{$417 \mathrm{~B}$} & Trans. & A5 & 1 & Red Pine (Pinus resinosa) & 16.5 & 162 & 53 \\
\hline & & & 2 & Red Pine (Pinus resinosa) & 18.3 & 186 & 203 \\
\hline & & & 3 & Red Pine (Pinus resinosa) & 20 & 182 & 57 \\
\hline & & & 4 & Red Pine (Pinus resinosa) & 19.5 & 582 & 51 \\
\hline & & D8 & 1 & Red Pine (Pinus resinosa) & 33 & 122 & 53 \\
\hline & & & 2 & Red Pine (Pinus resinosa) & 14.5 & 254 & 19 \\
\hline
\end{tabular}




\section{Appendix K. (continued)}

\begin{tabular}{|c|c|c|c|c|c|c|c|}
\hline Site & $\begin{array}{l}\text { Side of } \\
\text { Highway }\end{array}$ & $\begin{array}{l}\text { Sampling } \\
\text { Plot }\end{array}$ & $\begin{array}{c}\text { Quarter } \\
\text { of } \\
10 \times 10 \mathrm{~m} \\
\text { Plot } \\
\end{array}$ & Tree Species & $\begin{array}{l}\text { DBH } \\
(\mathbf{c m})\end{array}$ & $\begin{array}{c}\text { Tree } \\
\text { Dispersion } \\
\text { (cm) }\end{array}$ & $\begin{array}{c}\text { Fallen } \\
\text { Log } \\
\text { Dispersion } \\
\text { (cm) } \\
\end{array}$ \\
\hline \multirow[t]{10}{*}{$417 \mathrm{~B}$} & Trans. & D8 & 3 & Red Pine (Pinus resinosa) & 28 & 523 & 27 \\
\hline & & & 4 & Red Pine (Pinus resinosa) & 18.6 & 383 & 27 \\
\hline & & D1 & 1 & Eastern White Cedar (Thuja occidentalis) & 14.3 & 188 & $\mathrm{n} / \mathrm{a}$ \\
\hline & & & 2 & Eastern White Cedar (Thuja occidentalis) & 10.1 & 176 & $\mathrm{n} / \mathrm{a}$ \\
\hline & & & 3 & Eastern White Cedar (Thuja occidentalis) & 15.2 & 179 & $\mathrm{n} / \mathrm{a}$ \\
\hline & & & 4 & Eastern White Cedar (Thuja occidentalis) & 12 & 388 & $\mathrm{n} / \mathrm{a}$ \\
\hline & & G5 & 1 & Red Pine (Pinus resinosa) & 13.5 & 269 & 72 \\
\hline & & & 2 & Red Pine (Pinus resinosa) & 17.5 & 197 & 27 \\
\hline & & & 3 & Pin Cherry (Prunus pensylvanica) & 12.7 & 622 & 21 \\
\hline & & & 4 & Red Pine (Pinus resinosa) & 16.2 & 164 & 64 \\
\hline \multirow[t]{16}{*}{$417 \mathrm{~F}$} & Trap & A5 & 1 & Eastern White Cedar (Thuja occidentalis) & 18.1 & 136 & 6 \\
\hline & & & 2 & Sugar Maple (Acer saccharum) & 14.1 & 274 & 19 \\
\hline & & & 3 & Eastern White Cedar (Thuja occidentalis) & 21.7 & 240 & 74 \\
\hline & & & 4 & Sugar Maple (Acer saccharum) & 12.9 & 486 & 43 \\
\hline & & D8 & 1 & Black Ash (Fraxinus nigra) & 34.2 & 423 & 47 \\
\hline & & & 2 & Black Ash (Fraxinus nigra) & 27.7 & 502 & 22 \\
\hline & & & 3 & Black Ash (Fraxinus nigra) & 54.4 & 436 & 33 \\
\hline & & & 4 & Red Maple (Acer rubrum) & 10.2 & 317 & 34 \\
\hline & & D1 & 1 & Sugar Maple (Acer saccharum) & 11.9 & 196 & 24 \\
\hline & & & 2 & Sugar Maple (Acer saccharum) & 14.4 & 274 & 36 \\
\hline & & & 3 & Black Ash (Fraxinus nigra) & 11.2 & 501 & 94 \\
\hline & & & 4 & Sugar Maple (Acer saccharum) & 19.2 & 306 & 70 \\
\hline & & G5 & 1 & American Basswood (Tilia americana) & 14.8 & 24.7 & 19 \\
\hline & & & 2 & Black Ash (Fraxinus nigra) & 12.5 & 493 & 8 \\
\hline & & & 3 & Balsam Fir (Abies balsamea) & 30.2 & 432 & 18 \\
\hline & & & 4 & Balsam Fir (Abies balsamea) & 25.2 & 126 & 39 \\
\hline \multirow[t]{16}{*}{$417 \mathrm{~F}$} & Trans. & A5 & 1 & Ironwood (Ostrya virginiana) & 17.2 & 273 & 34 \\
\hline & & & 2 & Ironwood (Ostrya virginiana) & 17.3 & 139 & 109 \\
\hline & & & 3 & Ironwood (Ostrya virginiana) & 15.3 & 421 & 43 \\
\hline & & & 4 & Black Ash (Fraxinus nigra) & 23.7 & 502 & 96 \\
\hline & & D8 & 1 & Sugar Maple (Acer saccharum) & 26.8 & 207 & 103 \\
\hline & & & 2 & Sugar Maple (Acer saccharum) & 21.7 & 172 & 83 \\
\hline & & & 3 & Balsam Fir (Abies balsamea) & 11.3 & 357 & 45 \\
\hline & & & 4 & Balsam Fir (Abies balsamea) & 10.6 & 324 & 111 \\
\hline & & D1 & 1 & White Ash (Fraxinus americana) & 18.4 & 161 & 106 \\
\hline & & & 2 & Silver Maple (Acer saccharinum) & 39.2 & 326 & 84 \\
\hline & & & 3 & White Ash (Fraxinus americana) & 24.5 & 187 & 109 \\
\hline & & & 4 & White Ash (Fraxinus americana) & 26.4 & 320 & 104 \\
\hline & & G5 & 1 & Sugar Maple (Acer saccharum) & 33.2 & 207 & 19 \\
\hline & & & 2 & Eastern Hemlock (Tsuga canadensis) & 29.9 & 162 & 9 \\
\hline & & & 3 & Black Ash (Fraxinus nigra) & 10.2 & 256 & 13 \\
\hline & & & 4 & American Basswood (Tilia americana) & 12.4 & 231 & 58 \\
\hline \multirow[t]{4}{*}{$417 \mathrm{C}$} & Trap & A5 & 1 & Red Maple (Acer rubrum) & 12.5 & 311 & 41 \\
\hline & & & 2 & Red Maple (Acer rubrum) & 16.4 & 45 & 92 \\
\hline & & & 3 & Red Maple (Acer rubrum) & 13.7 & 251 & 45 \\
\hline & & & 4 & Red Maple (Acer rubrum) & 10.1 & 226 & 67 \\
\hline
\end{tabular}


Appendix K. (continued)

\begin{tabular}{|c|c|c|c|c|c|c|c|}
\hline Site & $\begin{array}{l}\text { Side of } \\
\text { Highway }\end{array}$ & $\begin{array}{l}\text { Sampling } \\
\text { Plot }\end{array}$ & $\begin{array}{c}\text { Quarter } \\
\text { of } \\
10 \times 10 \mathrm{~m} \\
\text { Plot } \\
\end{array}$ & Tree Species & $\begin{array}{l}\text { DBH } \\
\text { (cm) }\end{array}$ & $\begin{array}{c}\text { Tree } \\
\text { Dispersion } \\
\text { (cm) }\end{array}$ & $\begin{array}{c}\text { Fallen } \\
\text { Log } \\
\text { Dispersion } \\
\text { (cm) }\end{array}$ \\
\hline \multirow[t]{12}{*}{$417 \mathrm{C}$} & Trap & D8 & 1 & Sugar Maple (Acer saccharum) & 27.2 & 491 & 210 \\
\hline & & & 2 & $\begin{array}{l}\text { Red Maple (Acer rubrum) } \\
\text { Large-toothed aspen (Populus }\end{array}$ & 17.5 & 482 & 231 \\
\hline & & & 3 & grandidentata) & 40.5 & 341 & 80 \\
\hline & & & 4 & Red Maple (Acer rubrum) & 16.5 & 521 & 71 \\
\hline & & D1 & 1 & Sugar Maple (Acer saccharum) & 17.1 & 211 & 91 \\
\hline & & & 2 & Sugar Maple (Acer saccharum) & 19 & 381 & 101 \\
\hline & & & 3 & Red Maple (Acer rubrum) & 15.2 & 480 & 64 \\
\hline & & & 4 & Sugar Maple (Acer saccharum) & 16.1 & 6.1 & 116 \\
\hline & & G5 & 1 & Red Maple (Acer rubrum) & 15.5 & 755 & 101 \\
\hline & & & 2 & none & $\mathrm{n} / \mathrm{a}$ & $\mathrm{n} / \mathrm{a}$ & 2 \\
\hline & & & 3 & Sugar Maple (Acer saccharum) & 28.3 & 311 & 86 \\
\hline & & & 4 & Red Maple (Acer rubrum) & 26 & 842 & 213 \\
\hline \multirow[t]{16}{*}{$417 \mathrm{C}$} & Trans. & A5 & 1 & Red Maple (Acer rubrum) & 10.3 & 331 & 26 \\
\hline & & & 2 & White Elm (Ulmus americana) & 15.5 & 270 & 72 \\
\hline & & & 3 & Black Ash (Fraxinus nigra) & 11.2 & 163 & 66 \\
\hline & & & 4 & Trembling Aspen (Populus tremuloides) & 12.4 & 182 & 132 \\
\hline & & D8 & 1 & White Ash (Fraxinus americana) & 19.5 & 312 & 56 \\
\hline & & & 2 & White Ash (Fraxinus americana) & 20.1 & 317 & 105 \\
\hline & & & 3 & Red Maple (Acer rubrum) & 16.3 & 261 & 119 \\
\hline & & & 4 & Red Maple (Acer rubrum) & 10.7 & 171 & 99 \\
\hline & & D1 & 1 & Red Maple (Acer rubrum) & 14.6 & 140 & 31 \\
\hline & & & 2 & Red Maple (Acer rubrum) & 14.9 & 152 & 86 \\
\hline & & & 3 & White Birch (Betula papyrifera) & 11.6 & 214 & 106 \\
\hline & & & 4 & none & $\mathrm{n} / \mathrm{a}$ & $\mathrm{n} / \mathrm{a}$ & 91 \\
\hline & & G5 & 1 & Red Maple (Acer rubrum) & 13.6 & 133 & 82 \\
\hline & & & 2 & Red Maple (Acer rubrum) & 13.8 & 162 & 127 \\
\hline & & & 3 & none & $\mathrm{n} / \mathrm{a}$ & $\mathrm{n} / \mathrm{a}$ & 146 \\
\hline & & & 4 & none & $\mathrm{n} / \mathrm{a}$ & $\mathrm{n} / \mathrm{a}$ & 314 \\
\hline \multirow[t]{16}{*}{$417 \mathrm{E}$} & Trap & A5 & 1 & Red Maple (Acer rubrum) & 19.1 & 421 & 18 \\
\hline & & & 2 & Red Maple (Acer rubrum) & 43.3 & 272 & 77 \\
\hline & & & 3 & Red Maple (Acer rubrum) & 11.6 & 367 & 59 \\
\hline & & & 4 & none & $\mathrm{n} / \mathrm{a}$ & $\mathrm{n} / \mathrm{a}$ & 36 \\
\hline & & D8 & 1 & Red Maple (Acer rubrum) & 10.2 & 57 & 89 \\
\hline & & & 2 & Red Maple (Acer rubrum) & 13.5 & 187 & 203 \\
\hline & & & 3 & Red Maple (Acer rubrum) & 27.6 & 491 & 142 \\
\hline & & & 4 & Red Maple (Acer rubrum) & 27.2 & 421 & 238 \\
\hline & & D1 & 1 & Red Maple (Acer rubrum) & 32 & 205 & 62 \\
\hline & & & 2 & Red Maple (Acer rubrum) & 13.3 & 613 & 23 \\
\hline & & & 3 & Red Maple (Acer rubrum) & 19.1 & 252 & 32 \\
\hline & & & 4 & Red Maple (Acer rubrum) & 14.1 & 391 & 147 \\
\hline & & G5 & 1 & Red Maple (Acer rubrum) & 28.8 & 109 & 62 \\
\hline & & & 2 & Red Maple (Acer rubrum) & 13.1 & 126 & 41 \\
\hline & & & 3 & Yellow Birch (Betula alleghaniensis) & 11.3 & 310 & 39 \\
\hline & & & 4 & Red Maple (Acer rubrum) & 13.6 & 316 & 82 \\
\hline $417 \mathrm{E}$ & Trans. & A5 & 1 & Red Maple (Acer rubrum) & 54.4 & 473 & 151 \\
\hline
\end{tabular}




\section{Appendix K. (continued)}

\begin{tabular}{|c|c|c|c|c|c|c|c|}
\hline Site & $\begin{array}{c}\text { Side of } \\
\text { Highway }\end{array}$ & $\begin{array}{l}\text { Sampling } \\
\text { Plot }\end{array}$ & $\begin{array}{c}\text { Quarter } \\
\text { of } \\
10 \times 10 \mathrm{~m} \\
\text { Plot } \\
\end{array}$ & Tree Species & $\begin{array}{c}\text { DBH } \\
(\mathbf{c m})\end{array}$ & $\begin{array}{c}\text { Tree } \\
\text { Dispersion } \\
\text { (cm) }\end{array}$ & $\begin{array}{c}\text { Fallen } \\
\text { Log } \\
\text { Dispersion } \\
\text { (cm) } \\
\end{array}$ \\
\hline \multirow[t]{15}{*}{$417 \mathrm{E}$} & Trans. & A5 & 2 & Red Maple (Acer rubrum) & 39.2 & 511 & 113 \\
\hline & & & 3 & Red Maple (Acer rubrum) & 29.4 & 375 & 77 \\
\hline & & & 4 & none & $\mathbf{n} / \mathbf{a}$ & $\mathrm{n} / \mathrm{a}$ & 243 \\
\hline & & D8 & 1 & Red Maple (Acer rubrum) & 15.8 & 157 & 146 \\
\hline & & & 2 & Red Maple (Acer rubrum) & 33.5 & 273 & 310 \\
\hline & & & 3 & Red Maple (Acer rubrum) & 44.4 & 457 & 21 \\
\hline & & & 4 & Red Maple (Acer rubrum) & 30.1 & 420 & 76 \\
\hline & & D1 & 1 & Red Maple (Acer rubrum) & 23.4 & 286 & 28 \\
\hline & & & 2 & Red Maple (Acer rubrum) & 43.3 & 311 & 34 \\
\hline & & & 3 & Red Maple (Acer rubrum) & 22.6 & 172 & 65 \\
\hline & & & 4 & Red Maple (Acer rubrum) & 27.9 & 317 & 112 \\
\hline & & G5 & 1 & Red Maple (Acer rubrum) & 43 & 216 & 58 \\
\hline & & & 2 & Red Maple (Acer rubrum) & 36.9 & 247 & 172 \\
\hline & & & 3 & none & $\mathbf{n} / \mathbf{a}$ & $\mathrm{n} / \mathrm{a}$ & 83 \\
\hline & & & 4 & Red Maple (Acer rubrum) & 17.6 & 223 & 132 \\
\hline \multirow[t]{16}{*}{$417 \mathrm{H}$} & Trap & A5 & 1 & Black Spruce (Picea mariana) & 32.8 & 170 & 33 \\
\hline & & & 2 & Red Maple (Acer rubrum) & 42.7 & 392 & 39 \\
\hline & & & 3 & Red Maple (Acer rubrum) & 10.5 & 387 & 21 \\
\hline & & & 4 & Trembling Aspen (Populus tremuloides) & 35.3 & 502 & 32 \\
\hline & & D8 & 1 & Red Maple (Acer rubrum) & 10.7 & 82 & 43 \\
\hline & & & 2 & White Birch (Betula papyrifera) & 12.1 & 411 & 36 \\
\hline & & & 3 & Red Maple (Acer rubrum) & 11 & 321 & 73 \\
\hline & & & 4 & Black Spruce (Picea mariana) & 29.3 & 452 & 42 \\
\hline & & D1 & 1 & Red Pine (Pinus resinosa) & 33.4 & 111 & 25 \\
\hline & & & 2 & Red Pine (Pinus resinosa) & 26.9 & 274 & 51 \\
\hline & & & 3 & Red Maple (Acer rubrum) & 24.3 & 181 & 74 \\
\hline & & & 4 & Black Spruce (Picea mariana) & 25 & 283 & 78 \\
\hline & & G5 & 1 & Black Spruce (Picea mariana) & 29.3 & 187 & 46 \\
\hline & & & 2 & Black Spruce (Picea mariana) & 35.3 & 401 & 18 \\
\hline & & & 3 & Black Spruce (Picea mariana) & 26.6 & 386 & 54 \\
\hline & & & 4 & none & $\mathrm{n} / \mathbf{a}$ & $\mathrm{n} / \mathrm{a}$ & 129 \\
\hline \multirow[t]{16}{*}{$417 \mathrm{H}$} & Trans. & A5 & 1 & Red Maple (Acer rubrum) & 32 & 171 & 51 \\
\hline & & & 2 & White Birch (Betula papyrifera) & 11.2 & 134 & 32 \\
\hline & & & 3 & Red Maple (Acer rubrum) & 14.5 & 213 & 41 \\
\hline & & & 4 & Red Maple (Acer rubrum) & 12.6 & 126 & 53 \\
\hline & & D8 & 1 & White Elm (Ulmus americana) & 23.9 & 231 & 18 \\
\hline & & & 2 & Black Cherry (Prunus serotina) & 12.9 & 311 & 42 \\
\hline & & & 3 & Red Maple (Acer rubrum) & 38.5 & 510 & 57 \\
\hline & & & 4 & Red Maple (Acer rubrum) & 27.2 & 419 & 26 \\
\hline & & D1 & 1 & White Birch (Betula papyrifera) & 10.1 & 156 & 119 \\
\hline & & & 2 & Yellow Birch (Betula alleghaniensis) & 12 & 57 & 32 \\
\hline & & & 3 & White Birch (Betula papyrifera) & 17.8 & 212 & 26 \\
\hline & & & 4 & none & $\mathrm{n} / \mathrm{a}$ & $\mathbf{n} / \mathbf{a}$ & 4 \\
\hline & & G5 & 1 & Red Maple (Acer rubrum) & 11.7 & 201 & 21 \\
\hline & & & 2 & Red Maple (Acer rubrum) & 14.9 & 226 & 61 \\
\hline & & & 3 & Red Maple (Acer rubrum) & 18.8 & 187 & 52 \\
\hline & & & 4 & none & $\mathrm{n} / \mathrm{a}$ & $\mathrm{n} / \mathbf{a}$ & 54 \\
\hline
\end{tabular}




\section{Appendix K. (continued)}

\begin{tabular}{|c|c|c|c|c|c|c|c|}
\hline Site & $\begin{array}{c}\text { Side of } \\
\text { Highway }\end{array}$ & $\begin{array}{l}\text { Sampling } \\
\text { Plot }\end{array}$ & $\begin{array}{c}\text { Quarter } \\
\text { of } \\
10 \times 10 \mathrm{~m} \\
\text { Plot } \\
\end{array}$ & Tree Species & $\begin{array}{l}\text { DBH } \\
(\mathbf{c m})\end{array}$ & $\begin{array}{c}\text { Tree } \\
\text { Dispersion } \\
\text { (cm) }\end{array}$ & $\begin{array}{c}\text { Fallen } \\
\text { Log } \\
\text { Dispersion } \\
\text { (cm) } \\
\end{array}$ \\
\hline \multirow[t]{16}{*}{$417 \mathrm{~A}$} & \multirow[t]{16}{*}{ Trap } & \multirow[t]{4}{*}{ A5 } & 1 & Red Maple (Acer rubrum) & 13.3 & 297 & 31 \\
\hline & & & 2 & Red Maple (Acer rubrum) & 10.2 & 261 & 32 \\
\hline & & & 3 & Balsam Fir (Abies balsamea) & 14.8 & 311 & 26 \\
\hline & & & 4 & White Pine (Pinus strobus) & 40.3 & 512 & 7 \\
\hline & & \multirow[t]{4}{*}{ D8 } & 1 & Eastem White Cedar (Thuja occidentalis) & 36.2 & 32 & 18 \\
\hline & & & 2 & Eastem White Cedar (Thuja occidentalis) & 19.5 & 143 & 47 \\
\hline & & & 3 & Eastern White Cedar (Thuja occidentalis) & 24.6 & 329 & 307 \\
\hline & & & 4 & Eastem White Cedar (Thuja occidentalis) & 35.5 & 207 & 226 \\
\hline & & \multirow[t]{4}{*}{ D1 } & 1 & Yellow Birch (Betula alleghaniensis) & 16.9 & 41 & 52 \\
\hline & & & 2 & Red Maple (Acer rubrum) & 13.4 & 247 & 64 \\
\hline & & & 3 & Eastem White Pine (Pinus strobus) & 55.4 & 553 & 43 \\
\hline & & & 4 & Yellow Birch (Betula alleghaniensis) & 18.6 & 472 & 52 \\
\hline & & \multirow[t]{4}{*}{ G5 } & 1 & Red Maple (Acer rubrum) & 24.2 & 261 & 98 \\
\hline & & & 2 & White Birch (Betula papyrifera) & 13.9 & 307 & 128 \\
\hline & & & 3 & Yellow Birch (Betula alleghaniensis) & 10.8 & 47 & 17 \\
\hline & & & 4 & Eastern White Cedar (Thuja occidentalis) & 27.9 & 462 & 19 \\
\hline \multirow[t]{16}{*}{$417 \mathrm{~A}$} & \multirow[t]{16}{*}{ Trans. } & \multirow[t]{4}{*}{ A5 } & 1 & Eastern White Cedar (Thuja occidentalis) & 12.8 & 291 & 72 \\
\hline & & & 2 & Eastem White Cedar (Thuja occidentalis) & 16.7 & 307 & 48 \\
\hline & & & 3 & Eastern White Cedar (Thuja occidentalis) & 12.3 & 226 & 74 \\
\hline & & & 4 & Red Maple (Acer rubrum) & 44.9 & 417 & 96 \\
\hline & & \multirow[t]{4}{*}{ D8 } & 1 & Red Maple (Acer rubrum) & 19 & 140 & 43 \\
\hline & & & 2 & Red Maple (Acer rubrum) & 24.2 & 213 & 22 \\
\hline & & & 3 & Red Maple (Acer rubrum) & 20.1 & 312 & 121 \\
\hline & & & 4 & Eastern White Cedar (Thuja occidentalis) & 20.3 & 156 & 94 \\
\hline & & \multirow[t]{4}{*}{ D1 } & 1 & $\begin{array}{l}\text { Red Maple (Acer rubrum) } \\
\text { Large-toothed aspen (Populus }\end{array}$ & 22.3 & 206 & 20 \\
\hline & & & 2 & grandidentata) & 49 & 152 & 38 \\
\hline & & & 3 & Red Maple (Acer rubrum) & 13.1 & 221 & 7 \\
\hline & & & 4 & Black Ash (Fraxinus nigra) & 11.2 & 403 & 141 \\
\hline & & \multirow[t]{4}{*}{ G5 } & 1 & Red Maple (Acer rubrum) & 10.3 & 224 & 58 \\
\hline & & & 2 & Black Ash (Fraxinus nigra) & 18.6 & 271 & 129 \\
\hline & & & 3 & White Birch (Betula papyrifera) & 24.9 & 307 & 203 \\
\hline & & & 4 & White Elm (Ulmus americana) & 13.7 & 203 & 38 \\
\hline \multirow[t]{14}{*}{$416 \mathrm{C}$} & \multirow[t]{14}{*}{ Trap } & \multirow[t]{4}{*}{ A5 } & 1 & Black Ash (Fraxinus nigra) & 28.7 & 149 & 41 \\
\hline & & & 2 & Eastem White Cedar (Thuja occidentalis) & 12.5 & 284 & 46 \\
\hline & & & 3 & Black Ash (Fraxinus nigra) & 14 & 416 & 59 \\
\hline & & & 4 & Eastern White Cedar (Thuja occidentalis) & 12.2 & 407 & 47 \\
\hline & & \multirow[t]{4}{*}{ D8 } & 1 & Eastern White Cedar (Thuja occidentalis) & 13 & 122 & 26 \\
\hline & & & 2 & Trembling Aspen (Populus tremuloides) & 10.2 & 346 & 23 \\
\hline & & & 3 & Black Ash (Fraxinus nigra) & 10.1 & 76 & 54 \\
\hline & & & 4 & Eastern White Cedar (Thuja occidentalis) & 20 & 301 & 34 \\
\hline & & \multirow[t]{4}{*}{ D1 } & 1 & Eastern White Cedar (Thuja occidentalis) & 16 & 98 & 40 \\
\hline & & & 2 & Eastern White Cedar (Thuja occidentalis) & 15.5 & 170 & 37 \\
\hline & & & 3 & Eastern White Cedar (Thuja occidentalis) & 22.2 & 193 & 69 \\
\hline & & & 4 & Eastern White Cedar (Thuja occidentalis) & 14 & 174 & 55 \\
\hline & & \multirow[t]{2}{*}{ G5 } & 1 & Eastern White Cedar (Thuja occidentalis) & 20 & 192 & 69 \\
\hline & & & 2 & White Ash (Fraxinus americana) & 14.5 & 411 & 42 \\
\hline
\end{tabular}


Appendix K. (continued)

\begin{tabular}{|c|c|c|c|c|c|c|c|}
\hline Site & $\begin{array}{l}\text { Side of } \\
\text { Highway }\end{array}$ & $\underset{\text { Plot }}{\text { Sampling }}$ & 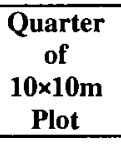 & Tree Species & $\begin{array}{c}\text { DBH } \\
(\mathbf{c m})\end{array}$ & $\begin{array}{c}\text { Tree } \\
\text { Dispersion } \\
\text { (cm) }\end{array}$ & $\begin{array}{c}\text { Fallen } \\
\text { Log } \\
\text { Dispersion } \\
\text { (cm) } \\
\end{array}$ \\
\hline \multirow{2}{*}{$416 \mathrm{C}$} & Trap & G5 & 3 & Eastern White Cedar (Thuja occidentalis) & 20 & 150 & 92 \\
\hline & & & 4 & Balsam Fir (Abies balsamea) & 12 & 229 & 75 \\
\hline \multirow[t]{16}{*}{$416 \mathrm{C}$} & Trans. & A5 & 1 & Eastern White Cedar (Thuja occidentalis) & 13 & 143 & 129 \\
\hline & & & 2 & Eastern White Cedar (Thuja occidentalis) & 15.7 & 115 & 61 \\
\hline & & & 3 & Eastern White Cedar (Thuja occidentalis) & 24 & 158 & 105 \\
\hline & & & 4 & Trembling Aspen (Populus tremuloides) & 31 & 209 & 74 \\
\hline & & D8 & 1 & Eastern White Cedar (Thuja occidentalis) & 11.5 & 99 & 106 \\
\hline & & & 2 & Eastern White Cedar (Thuja occidentalis) & 14.5 & 130 & 82 \\
\hline & & & 3 & Eastern White Cedar (Thuja occidentalis) & 22 & 106 & 99 \\
\hline & & & 4 & Eastern White Cedar (Thuja occidentalis) & 14.7 & 241 & 138 \\
\hline & & D1 & 1 & none & $\mathbf{n} / \mathbf{a}$ & $\mathrm{n} / \mathrm{a}$ & $\mathrm{n} / \mathbf{a}$ \\
\hline & & & 2 & none & $\mathrm{n} / \mathbf{a}$ & $\mathrm{n} / \mathrm{a}$ & $\mathrm{n} / \mathrm{a}$ \\
\hline & & & 3 & none & $\mathrm{n} / \mathrm{a}$ & $\mathrm{n} / \mathrm{a}$ & $\mathrm{n} / \mathrm{a}$ \\
\hline & & & 4 & none & $\mathrm{n} / \mathrm{a}$ & $\mathrm{n} / \mathrm{a}$ & $\mathrm{n} / \mathrm{a}$ \\
\hline & & G5 & 1 & Eastern White Cedar (Thuja occidentalis) & 12 & 98 & 24 \\
\hline & & & 2 & Eastem White Cedar (Thuja occidentalis) & 18.3 & 131 & 38 \\
\hline & & & 3 & Eastem White Cedar (Thuja occidentalis) & 11 & 74 & 43 \\
\hline & & & 4 & Eastem White Cedar (Thuja occidentalis) & 12.8 & 136 & 64 \\
\hline \multirow[t]{16}{*}{$416 \mathrm{~B}$} & Trap & A5 & 1 & Eastern White Cedar (Thuja occidentalis) & 22.6 & 355 & 26 \\
\hline & & & 2 & Eastern White Cedar (Thuja occidentalis) & 21.7 & 259 & 44 \\
\hline & & & 3 & White Ash (Fraxinus americana) & 19.3 & 382 & 59 \\
\hline & & & 4 & Eastern White Cedar (Thuja occidentalis) & 19.6 & 233 & 28 \\
\hline & & D8 & 1 & White Elm (Ulmus americana) & 47.8 & 437 & 60 \\
\hline & & & 2 & Black Ash (Fraxinus nigra) & 12.5 & 411 & 80 \\
\hline & & & 3 & Eastem White Cedar (Thuja occidentalis) & 17.5 & 343 & 93 \\
\hline & & & 4 & none & $\mathrm{n} / \mathbf{a}$ & $\mathrm{n} / \mathrm{a}$ & 53 \\
\hline & & D1 & 1 & White Ash (Fraxinus americana) & 22.6 & 305 & 43 \\
\hline & & & 2 & Black Ash (Fraxinus nigra) & 35.4 & 268 & 89 \\
\hline & & & 3 & White Elm (Ulmus americana) & 26 & 467 & 81 \\
\hline & & & 4 & Black Ash (Fraxinus nigra) & 26.5 & 461 & 114 \\
\hline & & G5 & 1 & Black Ash (Fraxinus nigra) & 35 & 258 & 19 \\
\hline & & & 2 & Black Ash (Fraxinus nigra) & 34.5 & 523 & 84 \\
\hline & & & 3 & none & $\mathbf{n} / \mathbf{a}$ & $\mathrm{n} / \mathrm{a}$ & 75 \\
\hline & & & 4 & none & $\mathrm{n} / \mathbf{a}$ & $\mathrm{n} / \mathrm{a}$ & 36 \\
\hline \multirow[t]{12}{*}{$416 \mathrm{~B}$} & Trans. & A5 & 1 & Eastern White Pine (Pinus strobus) & 20.5 & 231 & 20 \\
\hline & & & 2 & Eastern White Pine (Pinus strobus) & 21.5 & 384 & 13 \\
\hline & & & 3 & Eastern White Pine (Pinus strobus) & 20 & 121 & 29 \\
\hline & & & 4 & Eastem White Pine (Pinus strobus) & 13 & 98 & 39 \\
\hline & & D8 & 1 & Black Ash (Fraxinus nigra) & 17.7 & 271 & 69 \\
\hline & & & 2 & Black Ash (Fraxinus nigra) & 14 & 196 & 33 \\
\hline & & & 3 & Black Ash (Fraxinus nigra) & 15 & 211 & 102 \\
\hline & & & 4 & Black Ash (Fraxinus nigra) & 10.5 & 403 & 77 \\
\hline & & D1 & 1 & Eastem White Cedar (Thuja occidentalis) & 15 & 133 & 10 \\
\hline & & & 2 & Eastem White Cedar (Thuja occidentalis) & 31.5 & 170 & 30 \\
\hline & & & 3 & Eastern White Cedar (Thuja occidentalis) & 16 & 82 & 29 \\
\hline & & & 4 & Eastern White Cedar (Thuja occidentalis) & 17.5 & 261 & 19 \\
\hline
\end{tabular}


Appendix K. (continued)

\begin{tabular}{|c|c|c|c|c|c|c|c|}
\hline Site & $\begin{array}{c}\text { Side of } \\
\text { Highway }\end{array}$ & $\begin{array}{l}\text { Sampling } \\
\text { Plot }\end{array}$ & $\begin{array}{c}\begin{array}{c}\text { Quarter } \\
\text { of } \\
10 \times 10 \mathrm{~m}\end{array} \\
\text { Plot } \\
\end{array}$ & Tree Species & $\begin{array}{c}\text { DBH } \\
\text { (cm) }\end{array}$ & $\begin{array}{c}\text { Tree } \\
\text { Dispersion } \\
\text { (cm) }\end{array}$ & $\begin{array}{c}\text { Fallen } \\
\text { Log } \\
\text { Dispersion } \\
\text { (cm) } \\
\end{array}$ \\
\hline \multirow[t]{4}{*}{$416 \mathrm{~B}$} & Trans. & G5 & 1 & Eastern White Pine (Pinus strobus) & 15.5 & 164 & 20 \\
\hline & & & 2 & Eastern White Pine (Pinus strobus) & 16 & 295 & 22 \\
\hline & & & 3 & Black Ash (Fraxinus nigra) & 10.1 & 211 & 29 \\
\hline & & & 4 & Black Ash (Fraxinus nigra) & 10.1 & 238 & 102 \\
\hline \multirow[t]{16}{*}{$416 \mathrm{~A}$} & Trap & A5 & 1 & Red Maple (Acer rubrum) & 23.1 & 460 & 31 \\
\hline & & & 2 & Ironwood (Ostrya virginiana) & 11.2 & 210 & 64 \\
\hline & & & 3 & Red Maple (Acer rubrum) & 44.8 & 370 & 59 \\
\hline & & & 4 & Red Maple (Acer rubrum) & 37.3 & 420 & 72 \\
\hline & & D8 & 1 & Red Maple (Acer rubrum) & 14.6 & 70 & 29 \\
\hline & & & 2 & Red Maple (Acer rubrum) & 35.1 & 230 & 43 \\
\hline & & & 3 & Red Maple (Acer rubrum) & 28.7 & 390 & 19 \\
\hline & & & 4 & none & $\mathrm{n} / \mathrm{a}$ & $\mathbf{n} / \mathbf{a}$ & 38 \\
\hline & & D1 & 1 & Red Maple (Acer rubrum) & 10.1 & 30 & 31 \\
\hline & & & 2 & Red Maple (Acer rubrum) & 18.9 & 360 & 132 \\
\hline & & & 3 & White Elm (Ulmus americana) & 19.2 & 470 & 96 \\
\hline & & & 4 & Black Ash (Fraxinus nigra) & 10.3 & 520 & 29 \\
\hline & & G5 & 1 & Red Maple (Acer rubrum) & 27.4 & 160 & 3 \\
\hline & & & 2 & Red Maple (Acer rubrum) & 16.3 & 120 & 71 \\
\hline & & & 3 & Red Maple (Acer rubrum) & 25.7 & 650 & 143 \\
\hline & & & 4 & none & $\mathrm{n} / \mathrm{a}$ & $n / a$ & 147 \\
\hline \multirow[t]{16}{*}{$416 \mathrm{~A}$} & Trans. & A5 & 1 & Red Maple (Acer rubrum) & 18.9 & 260 & 102 \\
\hline & & & 2 & Red Maple (Acer rubrum) & 34.6 & 260 & 97 \\
\hline & & & 3 & Red Maple (Acer rubrum) & 11.2 & 170 & 84 \\
\hline & & & 4 & Red Maple (Acer rubrum) & 19.7 & 490 & 109 \\
\hline & & D8 & 1 & Red Maple (Acer rubrum) & 40.2 & 230 & 22 \\
\hline & & & 2 & Red Maple (Acer rubrum) & 40.6 & 370 & 48 \\
\hline & & & 3 & none & $\mathrm{n} / \mathrm{a}$ & $\mathrm{n} / \mathrm{a}$ & 91 \\
\hline & & & 4 & none & $\mathrm{n} / \mathrm{a}$ & $\mathbf{n} / \mathbf{a}$ & 51 \\
\hline & & D1 & 1 & Red Maple (Acer rubrum) & 17.9 & 40 & 52 \\
\hline & & & 2 & American Basswood (Tilia americana) & 35.1 & 190 & 37 \\
\hline & & & 3 & American Basswood (Tilia americana) & 21.3 & 180 & 193 \\
\hline & & & 4 & Red Maple (Acer rubrum) & 23.9 & 210 & 96 \\
\hline & & G5 & 1 & Red Maple (Acer rubrum) & 22.4 & 80 & 6 \\
\hline & & & 2 & Red Maple (Acer rubrum) & 26.8 & 150 & 74 \\
\hline & & & 3 & Red Maple (Acer rubrum) & 20.7 & 340 & 77 \\
\hline & & & 4 & Red Maple (Acer rubrum) & 33.2 & 420 & 78 \\
\hline
\end{tabular}


Appendix L. Vegetation data collected in $10 \times 10 \mathrm{~m}$ plots at the trap and translocation sides of the highway for each study site. Variables were measured as followed: summed length of coarse woody debris that covered a $10 \mathrm{~m}$ transect (\% coarse woody debris), number of times (out of 4) the crosshairs of the ocular tube intersected canopy cover (proportion canopy cover), and the total number of times (out of 20) non-woody vegetation was detected at randomly chosen points in the $10 \times 10 \mathrm{~m}$ plot (proportion vegetation cover).

\begin{tabular}{|c|c|c|c|c|c|}
\hline SITE & SIDE & PLOT & $\begin{array}{c}\text { \% Coarse } \\
\text { Woody Debris }\end{array}$ & $\begin{array}{c}\text { Proportion } \\
\text { Canopy Cover }\end{array}$ & $\begin{array}{c}\text { Proportion } \\
\text { Vegetation Cover }\end{array}$ \\
\hline \multirow[t]{4}{*}{$417 \mathrm{D}$} & Trap & A5 & 5.60 & 1.00 & 0.35 \\
\hline & & D8 & 7.60 & 1.00 & 0.50 \\
\hline & & D1 & 8.80 & 1.00 & 0.50 \\
\hline & & G5 & 11.60 & 0.75 & 0.50 \\
\hline \multirow[t]{4}{*}{$417 \mathrm{D}$} & Translocation & A5 & 10.20 & 0.75 & 0.40 \\
\hline & & D8 & 8.00 & 0.75 & 0.30 \\
\hline & & D1 & 23.60 & 0.50 & 0.60 \\
\hline & & G5 & 5.30 & 0.50 & 0.45 \\
\hline \multirow[t]{4}{*}{$417 \mathrm{G}$} & Trap & A5 & 10.60 & 0.50 & 0.70 \\
\hline & & D8 & 14.50 & 0.50 & 0.65 \\
\hline & & D1 & 17.30 & 0.75 & 0.65 \\
\hline & & G5 & 9.80 & 0.25 & 0.60 \\
\hline \multirow[t]{4}{*}{$417 \mathrm{G}$} & Translocation & A5 & 10.20 & 0.75 & 0.40 \\
\hline & & D8 & 5.75 & 1.00 & 0.45 \\
\hline & & D1 & 1.85 & 0.75 & 0.45 \\
\hline & & G5 & 1.35 & 1.00 & 0.75 \\
\hline \multirow{4}{*}{$417 \mathrm{~B}$} & Trap & A5 & 5.70 & 0.75 & 0.50 \\
\hline & & D8 & 1.10 & 0.50 & 0.80 \\
\hline & & D1 & 7.50 & 0.75 & 0.90 \\
\hline & & G5 & 9.85 & 1.00 & 0.70 \\
\hline \multirow[t]{4}{*}{$417 \mathrm{~B}$} & Translocation & A5 & 1.10 & 1.00 & 0.55 \\
\hline & & D8 & 3.60 & 0.50 & 0.50 \\
\hline & & D1 & 0.40 & 0.75 & 0.60 \\
\hline & & G5 & 4.05 & 0.75 & 0.70 \\
\hline \multirow[t]{4}{*}{$417 \mathrm{~F}$} & Trap & A5 & 10.70 & 0.25 & 0.20 \\
\hline & & D8 & 8.10 & 0.25 & 0.10 \\
\hline & & D1 & 3.90 & 1.00 & 0.25 \\
\hline & & G5 & 14.20 & 1.00 & 0.25 \\
\hline \multirow[t]{4}{*}{$417 \mathrm{~F}$} & Translocation & A5 & 10.50 & 1.00 & 0.20 \\
\hline & & D8 & 9.40 & 0.50 & 0.20 \\
\hline & & D1 & 12.40 & 0.25 & 0.25 \\
\hline & & G5 & 4.90 & 0.75 & 0.10 \\
\hline \multirow[t]{4}{*}{$417 \mathrm{C}$} & Trap & A5 & 5.30 & 0.50 & 0.50 \\
\hline & & D8 & 5.10 & 0.75 & 0.40 \\
\hline & & D1 & 5.00 & 1.00 & 0.30 \\
\hline & & G5 & 5.00 & 1.00 & 0.55 \\
\hline \multirow[t]{3}{*}{$417 \mathrm{C}$} & Translocation & A5 & 5.60 & 0.50 & 0.55 \\
\hline & & D8 & 12.60 & 0.50 & 0.65 \\
\hline & & D1 & 4.70 & 0.25 & 0.60 \\
\hline
\end{tabular}


Appendix L. (continued)

\begin{tabular}{|c|c|c|c|c|c|}
\hline SITE & SIDE & PLOT & $\begin{array}{c}\% \text { Coarse } \\
\text { Woody Debris }\end{array}$ & $\begin{array}{c}\text { Proportion } \\
\text { Canopy Cover } \\
\end{array}$ & $\begin{array}{c}\text { Proportion } \\
\text { Vegetation Cover }\end{array}$ \\
\hline $417 \mathrm{C}$ & Translocation & G5 & 2.00 & 0.25 & 0.50 \\
\hline \multirow[t]{4}{*}{$417 \mathrm{E}$} & Trap & A5 & 7.20 & 0.50 & 0.65 \\
\hline & & D8 & 2.70 & 0.25 & 0.70 \\
\hline & & D1 & 15.80 & 0.75 & 0.35 \\
\hline & & G5 & 6.00 & 1.00 & 0.45 \\
\hline \multirow[t]{4}{*}{$417 \mathrm{E}$} & Translocation & A5 & 5.70 & 0.75 & 0.35 \\
\hline & & D8 & 3.80 & 1.00 & 0.30 \\
\hline & & D1 & 5.50 & 0.75 & 0.15 \\
\hline & & G5 & 6.90 & 0.25 & 0.25 \\
\hline \multirow[t]{4}{*}{$417 \mathrm{H}$} & Trap & A5 & 12.10 & 1.00 & 0.55 \\
\hline & & D8 & 9.50 & 0.75 & 0.60 \\
\hline & & D1 & 22.60 & 0.75 & 0.35 \\
\hline & & G5 & 5.30 & 0.75 & 0.50 \\
\hline \multirow[t]{4}{*}{$417 \mathrm{H}$} & Translocation & A5 & 9.40 & 0.50 & 0.60 \\
\hline & & D8 & 3.10 & 0.50 & 0.75 \\
\hline & & D1 & 5.10 & 0.50 & 0.60 \\
\hline & & G5 & 8.60 & 0.50 & 0.65 \\
\hline \multirow[t]{4}{*}{$417 \mathrm{~A}$} & Trap & A5 & 6.10 & 0.75 & 0.45 \\
\hline & & D8 & 1.80 & 0.25 & 0.20 \\
\hline & & D1 & 7.90 & 0.50 & 0.40 \\
\hline & & G5 & 3.20 & 1.00 & 0.30 \\
\hline \multirow[t]{4}{*}{$417 \mathrm{~A}$} & Translocation & A5 & 4.70 & 0.25 & 0.45 \\
\hline & & D8 & 2.80 & 0.25 & 0.55 \\
\hline & & D1 & 8.40 & 0.50 & 0.50 \\
\hline & & G5 & 4.90 & 0.50 & 0.95 \\
\hline \multirow[t]{4}{*}{$416 \mathrm{C}$} & Trap & A5 & 3.50 & 0.75 & 0.45 \\
\hline & & D8 & 4.55 & 1.00 & 0.45 \\
\hline & & D1 & 1.30 & 1.00 & 0.55 \\
\hline & & G5 & 5.40 & 0.75 & 0.65 \\
\hline \multirow[t]{4}{*}{$416 \mathrm{C}$} & Translocation & A5 & 0.90 & 1.00 & 0.05 \\
\hline & & D8 & 2.60 & 1.00 & 0.00 \\
\hline & & D1 & 0.00 & 0.00 & 1.00 \\
\hline & & G5 & 5.80 & 1.00 & 0.00 \\
\hline \multirow[t]{4}{*}{$416 \mathrm{~B}$} & Trap & A5 & 20.20 & 1.00 & 0.50 \\
\hline & & D8 & 5.75 & 1.00 & 0.30 \\
\hline & & D1 & 3.50 & 1.00 & 0.35 \\
\hline & & G5 & 6.30 & 0.25 & 0.90 \\
\hline \multirow[t]{4}{*}{$416 \mathrm{~B}$} & Translocation & A5 & 3.25 & 1.00 & 0.10 \\
\hline & & D8 & 3.20 & 0.50 & 0.70 \\
\hline & & D1 & 1.05 & 0.75 & 0.15 \\
\hline & & G5 & 0.70 & 1.00 & 0.30 \\
\hline \multirow[t]{4}{*}{$416 \mathrm{~A}$} & Trap & A5 & 7.50 & 1.00 & 0.40 \\
\hline & & D8 & 20.40 & 0.25 & 0.55 \\
\hline & & D1 & 2.20 & 0.25 & 0.25 \\
\hline & & G5 & 6.10 & 0.25 & 0.55 \\
\hline
\end{tabular}


Appendix L. (continued)

\begin{tabular}{cccccc}
\hline SITE & SIDE & PLOT & $\begin{array}{c}\text { \% Coarse } \\
\text { Woody Debris }\end{array}$ & $\begin{array}{c}\text { Proportion } \\
\text { Canopy Cover }\end{array}$ & $\begin{array}{c}\text { Proportion } \\
\text { Vegetation Cover }\end{array}$ \\
\hline \multirow{3}{*}{ 416 A } & \multirow{2}{*}{ Translocation } & A5 & 11.20 & & \\
& & 6.10 & 0.50 & 0.20 \\
& & D8 & 0.70 & 0.75 & 0.10 \\
& & D1 & 8.20 & 0.75 & 0.40 \\
& G5 & 1.00 & 0.40 \\
\hline
\end{tabular}


Appendix M. Counts of coniferous and deciduous shrubs, saplings, and small trees in $2 \times 2 \mathrm{~m}$ plots at the trap and translocation sides of the highway for the 11 study sites. Two $2 \times 2 \mathrm{~m}$ plots were sampled in each $10 \times 10 \mathrm{~m}$ vegetation plot.

\begin{tabular}{|c|c|c|c|c|c|c|c|c|c|c|c|c|c|c|}
\hline \multirow[t]{2}{*}{ SITE } & \multirow[t]{2}{*}{ SIDE } & \multirow[t]{2}{*}{ PLOT } & \multicolumn{2}{|c|}{$\begin{array}{c}\# \\
\text { Coniferous } \\
\text { Shrubs }\end{array}$} & \multicolumn{2}{|c|}{$\begin{array}{c}\# \\
\text { Deciduous } \\
\text { Shrubs }\end{array}$} & \multicolumn{2}{|c|}{$\begin{array}{c}\# \\
\text { Coniferous } \\
\text { Saplings }\end{array}$} & \multicolumn{2}{|c|}{$\begin{array}{c}\# \\
\text { Deciduous } \\
\text { Saplings }\end{array}$} & \multicolumn{2}{|c|}{$\begin{array}{c}\# \\
\text { Coniferous } \\
\text { Small } \\
\text { Trees } \\
\end{array}$} & \multicolumn{2}{|c|}{$\begin{array}{c}\# \\
\text { Deciduous } \\
\text { Small } \\
\text { Trees }\end{array}$} \\
\hline & & & 1 & 2 & 1 & 2 & 1 & 2 & 1 & 2 & 1 & 2 & 1 & 2 \\
\hline \multirow[t]{4}{*}{$417 \mathrm{D}$} & Trap & A5 & 0 & 0 & 0 & 0 & 0 & 0 & 6 & 4 & 0 & 0 & 1 & 0 \\
\hline & & D8 & 0 & 0 & 0 & 0 & 0 & 0 & 0 & 7 & 0 & 0 & 1 & 0 \\
\hline & & D1 & 0 & 0 & 0 & 0 & 0 & 0 & 3 & 1 & 0 & 0 & 0 & 2 \\
\hline & & G5 & 0 & 0 & 0 & 1 & 0 & 3 & 2 & 6 & 0 & 0 & 0 & 0 \\
\hline \multirow[t]{4}{*}{$417 \mathrm{D}$} & Trans. & A5 & 0 & 0 & 0 & 0 & 0 & 0 & 8 & 5 & 0 & 0 & 0 & 0 \\
\hline & & D8 & 0 & 0 & 0 & 0 & 1 & 0 & 0 & 1 & 0 & 0 & 0 & 0 \\
\hline & & D1 & 0 & 0 & 0 & 0 & 0 & 0 & 3 & 0 & 0 & 0 & 0 & 0 \\
\hline & & G5 & 0 & 0 & 19 & 0 & 0 & 0 & 1 & 1 & 0 & 0 & 0 & 0 \\
\hline \multirow[t]{4}{*}{$417 \mathrm{G}$} & Trap & A5 & 0 & 0 & 1 & 1 & 0 & 0 & 11 & 2 & 0 & 0 & 0 & 0 \\
\hline & & D8 & 0 & 0 & 1 & 1 & 0 & 0 & 7 & 3 & 0 & 0 & 0 & 1 \\
\hline & & D1 & 0 & 0 & 10 & 3 & 0 & 0 & 9 & 7 & 0 & 0 & 1 & 0 \\
\hline & & G5 & 0 & 0 & 3 & 4 & 0 & 0 & 4 & 7 & 0 & 0 & 0 & 0 \\
\hline \multirow[t]{4}{*}{$417 \mathrm{G}$} & Trans. & A5 & 0 & 0 & 0 & 0 & 0 & 0 & 6 & 7 & 0 & 0 & 0 & 0 \\
\hline & & D8 & 0 & 0 & 5 & 0 & 0 & 0 & 0 & 9 & 0 & 0 & 0 & 0 \\
\hline & & D1 & 0 & 0 & 0 & 0 & 0 & 0 & 6 & 0 & 0 & 0 & 2 & 0 \\
\hline & & G5 & 0 & 0 & 0 & 0 & 0 & 0 & 6 & 5 & 0 & 0 & 0 & 2 \\
\hline \multirow[t]{4}{*}{$417 \mathrm{~B}$} & Trap & A5 & 0 & 0 & 5 & 0 & 0 & 0 & 2 & 4 & 0 & 0 & 0 & 0 \\
\hline & & D8 & 0 & 0 & 1 & 20 & 0 & 0 & 0 & 0 & 0 & 0 & 0 & 0 \\
\hline & & D1 & 0 & 0 & 5 & 12 & 0 & 0 & 1 & 0 & 0 & 0 & 0 & 0 \\
\hline & & G5 & 0 & 0 & 3 & 10 & 0 & 0 & 5 & 0 & 0 & 0 & 1 & 0 \\
\hline \multirow[t]{4}{*}{$417 \mathrm{~B}$} & Trans. & A5 & 0 & 0 & 6 & 1 & 0 & 0 & 0 & 0 & 0 & 0 & 1 & 0 \\
\hline & & D8 & 0 & 0 & 2 & 0 & 2 & 5 & 0 & 0 & 0 & 0 & 0 & 0 \\
\hline & & D1 & 0 & 0 & 6 & 0 & 0 & 0 & 1 & 0 & 0 & 0 & 0 & 0 \\
\hline & & G5 & 0 & 0 & 11 & 0 & 0 & 0 & 0 & 0 & 0 & 0 & 0 & 2 \\
\hline \multirow[t]{4}{*}{$417 \mathrm{~F}$} & Trap & A5 & 0 & 0 & 2 & 2 & 2 & 0 & 0 & 1 & 0 & 0 & 1 & 0 \\
\hline & & D8 & 0 & 0 & 0 & 0 & 0 & 0 & 0 & 3 & 0 & 0 & 0 & 0 \\
\hline & & D1 & 0 & 0 & 0 & 0 & 0 & 3 & 0 & 0 & 0 & 0 & 2 & 0 \\
\hline & & G5 & 0 & 0 & 0 & 0 & 2 & 0 & 1 & 0 & 0 & 0 & 0 & 1 \\
\hline \multirow[t]{4}{*}{$417 \mathrm{~F}$} & Trans. & A5 & 0 & 0 & 0 & 0 & 0 & 2 & 0 & 5 & 1 & 0 & 3 & 0 \\
\hline & & D8 & 0 & 0 & 0 & 0 & 0 & 6 & 0 & 3 & 2 & 1 & 0 & 0 \\
\hline & & D1 & 0 & 0 & 0 & 0 & 0 & 2 & 6 & 0 & 0 & 1 & 0 & 1 \\
\hline & & G5 & 0 & 0 & 0 & 0 & 0 & 2 & 5 & 0 & 1 & 0 & 0 & 0 \\
\hline \multirow[t]{4}{*}{$417 \mathrm{C}$} & Trap & A5 & 0 & 0 & 0 & 0 & 0 & 0 & 1 & 3 & 0 & 0 & 2 & 1 \\
\hline & & D8 & 0 & 0 & 0 & 0 & 0 & 0 & 6 & 5 & 0 & 0 & 0 & 0 \\
\hline & & D1 & 0 & 0 & 0 & 0 & 0 & 0 & 14 & 10 & 0 & 0 & 1 & 0 \\
\hline & & G5 & 0 & 0 & 0 & 0 & 0 & 0 & 3 & 7 & 0 & 0 & 0 & 1 \\
\hline \multirow[t]{4}{*}{$417 \mathrm{C}$} & Trans. & A5 & 0 & 0 & 3 & 0 & 0 & 0 & 4 & 17 & 0 & 0 & 0 & 1 \\
\hline & & D8 & 0 & 0 & 0 & 0 & 0 & 0 & 7 & 14 & 0 & 0 & 0 & 0 \\
\hline & & D1 & 0 & 0 & 1 & 1 & 0 & 0 & 22 & 4 & 0 & 0 & 3 & 1 \\
\hline & & G5 & 0 & 0 & 0 & 1 & 0 & 0 & 8 & 2 & 0 & 0 & 1 & 0 \\
\hline $417 \mathrm{E}$ & Trap & A5 & 0 & 0 & 0 & 0 & 0 & 0 & 19 & 4 & 0 & 0 & 1 & 0 \\
\hline & & D8 & 0 & 0 & 0 & 0 & 0 & 0 & 8 & 2 & 0 & 0 & 0 & 0 \\
\hline & & D1 & 0 & 0 & 0 & 0 & 0 & 0 & 5 & 9 & 0 & 0 & 0 & 0 \\
\hline & & G5 & 0 & 0 & 0 & 0 & 0 & 0 & 15 & 3 & 0 & 0 & 0 & 0 \\
\hline
\end{tabular}


Appendix M. (continued)

\begin{tabular}{|c|c|c|c|c|c|c|c|c|c|c|c|c|c|c|}
\hline \multirow{2}{*}{$\begin{array}{l}\text { SITE } \\
417 \mathrm{E}\end{array}$} & \multirow{2}{*}{$\begin{array}{l}\text { SIDE } \\
\text { Trans. }\end{array}$} & \multirow{2}{*}{$\begin{array}{c}\text { PLOT } \\
\text { A5 }\end{array}$} & \multicolumn{2}{|c|}{$\begin{array}{c}\# \\
\text { Coniferous } \\
\text { Shrubs }\end{array}$} & \multicolumn{2}{|c|}{$\begin{array}{c}\# \\
\text { Deciduous } \\
\text { Shrubs }\end{array}$} & \multicolumn{2}{|c|}{$\begin{array}{c}\# \\
\text { Coniferous } \\
\text { Saplings }\end{array}$} & \multicolumn{2}{|c|}{$\begin{array}{c}\# \\
\text { Deciduous } \\
\text { Saplings }\end{array}$} & \multicolumn{2}{|c|}{$\begin{array}{c}\# \\
\text { Coniferous } \\
\text { Small } \\
\text { Trees } \\
\end{array}$} & \multicolumn{2}{|c|}{$\begin{array}{c}\# \\
\text { Deciduous } \\
\text { Small } \\
\text { Trees } \\
\end{array}$} \\
\hline & & & 0 & 0 & 0 & 0 & 0 & 0 & 15 & 7 & 0 & 0 & 0 & 0 \\
\hline & & D8 & 0 & 0 & 0 & 0 & 0 & 0 & 4 & 6 & 0 & 0 & 1 & 0 \\
\hline & & D1 & 0 & 0 & 0 & 0 & 0 & 0 & 13 & 4 & 0 & 0 & 0 & 0 \\
\hline & & G5 & 0 & 0 & 3 & 0 & 0 & 0 & 17 & 15 & 0 & 0 & 0 & 0 \\
\hline \multirow[t]{4}{*}{$417 \mathrm{H}$} & Trap & A5 & 0 & 0 & 1 & 0 & 0 & 0 & 4 & 5 & 0 & 1 & 0 & 0 \\
\hline & & D8 & 0 & 0 & 0 & 0 & 1 & 0 & 2 & 4 & 0 & 0 & 7 & 0 \\
\hline & & D1 & 0 & 0 & 1 & 0 & 0 & 3 & 2 & 9 & 0 & 0 & 0 & 0 \\
\hline & & G5 & 0 & 0 & 1 & 1 & 0 & 0 & 17 & 13 & 0 & 0 & 1 & 0 \\
\hline \multirow[t]{4}{*}{$417 \mathrm{H}$} & Trans. & A5 & 0 & 0 & 0 & 0 & 0 & 0 & 0 & 2 & 0 & 0 & 5 & 1 \\
\hline & & D8 & 0 & 1 & 0 & 0 & 0 & 0 & 1 & 0 & 0 & 0 & 1 & 0 \\
\hline & & D1 & 0 & 0 & 0 & 1 & 0 & 0 & 0 & 4 & 0 & 0 & 5 & 3 \\
\hline & & G5 & 0 & 0 & 0 & 0 & 0 & 0 & 15 & 6 & 0 & 0 & 2 & 2 \\
\hline \multirow[t]{4}{*}{$417 \mathrm{~A}$} & Trap & A5 & 0 & 0 & 0 & 0 & 0 & 0 & 0 & 4 & 0 & 0 & 2 & 0 \\
\hline & & D8 & 0 & 0 & 0 & 0 & 0 & 2 & 0 & 9 & 0 & 0 & 0 & 0 \\
\hline & & D1 & 0 & 0 & 0 & 0 & 2 & 0 & 1 & 3 & 0 & 0 & 0 & 0 \\
\hline & & G5 & 0 & 0 & 0 & 0 & 0 & 3 & 2 & 0 & 0 & 1 & 0 & 0 \\
\hline \multirow[t]{4}{*}{$417 \mathrm{~A}$} & Trans. & A5 & 0 & 0 & 0 & 0 & 0 & 0 & 0 & 2 & 0 & 0 & 0 & 1 \\
\hline & & D8 & 0 & 0 & 0 & 13 & 0 & 0 & 2 & 1 & 0 & 0 & 1 & 0 \\
\hline & & D1 & 0 & 0 & 0 & 1 & 0 & 0 & 11 & 0 & 0 & 0 & 0 & 0 \\
\hline & & G5 & 0 & 0 & 0 & 0 & 0 & 0 & 1 & 9 & 0 & 0 & 1 & 3 \\
\hline \multirow[t]{4}{*}{$416 \mathrm{C}$} & Trap & A5 & 0 & 0 & 4 & 3 & 3 & 0 & 0 & 0 & 0 & 0 & 0 & 0 \\
\hline & & D8 & 0 & 0 & 0 & 1 & 0 & 0 & 3 & 1 & 0 & 0 & 2 & 0 \\
\hline & & D1 & 0 & 0 & 5 & 0 & 0 & 0 & 0 & 3 & 0 & 0 & 0 & 0 \\
\hline & & G5 & 0 & 0 & 0 & 0 & 0 & 3 & 1 & 3 & 0 & 0 & 0 & 0 \\
\hline \multirow[t]{4}{*}{$416 \mathrm{C}$} & Trans. & A5 & 0 & 0 & 0 & 0 & 0 & 0 & 0 & 0 & 0 & 0 & 0 & 0 \\
\hline & & D8 & 0 & 0 & 0 & 0 & 0 & 0 & 0 & 0 & 2 & 1 & 0 & 0 \\
\hline & & D1 & 0 & 0 & 5 & 3 & 1 & 6 & 0 & 0 & 0 & 0 & 0 & 0 \\
\hline & & G5 & 0 & 0 & 0 & 0 & 0 & 0 & 0 & 0 & 0 & 1 & 0 & 0 \\
\hline \multirow[t]{4}{*}{$416 \mathrm{~B}$} & Trap & A5 & 0 & 0 & 6 & 17 & 0 & 0 & 0 & 1 & 0 & 0 & 0 & 0 \\
\hline & & D8 & 0 & 0 & 0 & 24 & 0 & 0 & 4 & 0 & 0 & 0 & 1 & 0 \\
\hline & & D1 & 0 & 0 & 6 & 1 & 0 & 0 & 8 & 3 & 0 & 0 & 0 & 0 \\
\hline & & G5 & 0 & 0 & 0 & 0 & 0 & 0 & 0 & 0 & 0 & 0 & 0 & 0 \\
\hline \multirow[t]{4}{*}{$416 \mathrm{~B}$} & Trans. & A5 & 0 & 0 & 0 & 4 & 0 & 0 & 0 & 0 & 0 & 1 & 0 & 0 \\
\hline & & D8 & 0 & 0 & 5 & 5 & 0 & 0 & 6 & 2 & 0 & 0 & 0 & 0 \\
\hline & & D1 & 0 & 0 & 1 & 0 & 0 & 0 & 0 & 0 & 0 & 0 & 0 & 0 \\
\hline & & G5 & 0 & 0 & 1 & 5 & 0 & 0 & 0 & 0 & 0 & 0 & 8 & 1 \\
\hline \multirow[t]{4}{*}{$416 \mathrm{~A}$} & Trap & A5 & 0 & 0 & 3 & 0 & 0 & 0 & 0 & 4 & 0 & 0 & 0 & 2 \\
\hline & & D8 & 0 & 0 & 2 & 0 & 0 & 0 & 0 & 7 & 0 & 0 & 0 & 0 \\
\hline & & D1 & 0 & 0 & 3 & 2 & 0 & 0 & 1 & 2 & 0 & 0 & 0 & 0 \\
\hline & & G5 & 0 & 0 & 9 & 3 & 0 & 0 & 0 & 2 & 0 & 0 & 0 & 0 \\
\hline \multirow[t]{4}{*}{$416 \mathrm{~A}$} & Trans. & A5 & 0 & 0 & 1 & 1 & 0 & 0 & 1 & 0 & 0 & 0 & 0 & 0 \\
\hline & & D8 & 0 & 0 & 3 & 0 & 0 & 0 & 1 & 1 & 0 & 0 & 3 & 2 \\
\hline & & D1 & 0 & 0 & 1 & 0 & 0 & 0 & 4 & 12 & 0 & 0 & 1 & 1 \\
\hline & & G5 & 0 & 0 & 2 & 0 & 0 & 0 & 3 & 8 & 0 & 0 & 1 & 1 \\
\hline
\end{tabular}

